\title{
Hay que Defender la Ciudad: De la Distopía del Confinamiento a la Ciudad Abierta
}

José María Ezquiaga Domínguez ${ }^{1}$

Recibido: 20-06-2020 | en su versión final: 30-06-2020

Resumen

La COVD-19 ha desestabilizado profundamente el espacio público y las infraestructuras vitales de la ciudad abriendo la posibilidad de impulsar tendencias disruptivas con la visión convencional de esta. La densidad está asociada a la noción de intensidad. Las ciudades deben afrontar la contradicción entre la densificación entendida como limitación racional del consumo de territorio y la dispersión territorial, que en el contexto de la pandemia parece a asociarse mejor al distanciamiento social. La intensidad de la interacción social estimula la innovación y la creación en las esferas económica, científica y cultural. Desde el punto de vista ambiental la densidad es clave para reducir de la huella urbana, el consumo energético y las emisiones de carbono. Las medidas de distanciamiento social durante la emergencia sanitaria han fortalecido la conciencia del valor de los vínculos entre personas y grupos diversos. Esto ha evidenciado las ventajas de los lugares donde la gente vive suficientemente cerca para acceder peatonalmente a los servicios que necesita y los beneficios colaterales de la reducción de la movilidad. Por otra parte, ha hecho patente el conflicto entre un espacio viario diseñado al servicio del automóvil, las necesidades de la movilidad peatonal y las demandas de las actividades económicas a pie de calle. Las viviendas productivas del confinamiento, en las que han convivido el trabajo y los cuidados, la conexión social y la intimidad personal, son la vanguardia de una transformación muy profunda de la arquitectura residencial. Proyectar la ciudad visible es una herramienta insuficiente para gestionar la complejidad urbana contemporánea, el cambio más profundo debe operarse en la renovación de la dialéctica entre las esferas de lo público y lo privado, incorporando la dimensión social y la experiencia temporal al proyecto espacial de la ciudad.

Palabras clave: urbanismo; ciudad; densidad, espacio público

Citación

Ezquiaga Domínguez, J. M. (2020). Hay que Defender la Ciudad: De la Distopía a la Ciudad Abierta. ACE: Architecture, City and Environment, 15(43), 9518. DOl: http://dx.doi.org/10.5821/ace.15.43.9518

\footnotetext{
${ }^{1}$ Doctor Arquitecto. Licenciado en Ciencias Políticas y Sociología. Profesor Titular del Departamento de Urbanismo y Ordenación del Territorio de la Universidad Politécnica de Madrid. (ORCID ID: 0000-00025637-789X). Correo de contacto: jm.ezquiaga@upm.es
}

ACE, 15 (4:3) CC BY-ND 3.0 ES | UPC Barcelona, España | Hay que Defender la Ciudad: De la Distopía a la Ciudad Abierta. DOI: http://dx.doi.org/10.5821/ace.15.43.9518 


\section{In Defense of the City: From Lock-down Dystopia to Open Cities}

Abstract

COVID-19 has deeply destabilised the city's basic infrastructures and its public space, prompting possible disruptive trends regarding the conventional image of the city. Density is associated with the notion of intensity. Intensity in social interaction is key to innovation and creativity in science, culture, and the economy. From an environmental point of view, density is crucial for the reduction of the urban footprint and lowering energy consumption and carbon emissions. One of the most urgent challenges that cities face is solving the contradiction between densification, understood as putting a rational limit to land use, and disperse growth, which in the context of the COVID-19 pandemic seems better suited for social distancing. Socialdistancing measures during the COVID-19 health emergency have stressed the importance of linkages between individuals and different groups. Moreover, they have highlighted the advantages of living in places where access to essential services is within walking distance, as well as the collateral benefits of mobility reduction. On the other hand, the conflict between road space, designed solely for the car, and spatial requirements for pedestrian mobility, as well as for economic activities at street level, has become ever more evident. Our productive homes, where work activity, family care, social connection, and personal intimacy have coexisted during the lock-down, are the forerunners of a deep transformation in residential architecture. In order to manage present-day urban complexity, it is not enough to plan or design the city which we can see. But the deepest change must take place in a renovation of the dialectics between the public and private spheres, incorporating both social and temporal dimensions into the spatial plans for the city.

Keywords: urban planning, city, density, public space

Lo que cuenta en los pensamientos de los hombres no es tanto lo que han pensado, sino lo no pensado, que desde el comienzo del juego los sistematiza, haciéndolos para el resto del tiempo indefinidamente accesibles al lenguaje y abiertos a la tarea de pensarlos de nuevo

Michel Foucault, El Nacimiento de la clínica.

\section{Introducción}

La aglomeración y circulación de personas y bienes que está en el origen de la riqueza y la cultura de las ciudades es al mismo tiempo la causa de su vulnerabilidad ante el azote de las plagas epidémicas y las crisis de escasez. Como se constata reiteradamente a lo largo de la historia, las grandes epidemias tienen la capacidad de desestabilizar el espacio público y las infraestructuras vitales de la ciudad y abrir, en consecuencia, tendencias disruptivas con la gobernanza urbana

ACE, 15 (4:3) CC BY-ND 3.0 ES | UPC Barcelona, España | Hay que Defender la Ciudad: De la Distopía a la Ciudad 
establecida dejando un legado duradero y todavía reconocible en la planificación urbana. (McNeill, 1976; Haggett, 2000; Vigarello, 1993; Guerrand, 1991; Prieto, 2019).

La ciudad reticulada e incluso la zonificación de usos asociada al concepto moderno de organización funcional de la ciudad tienen origen en los dispositivos de control administrativo de las ciudades afectadas por las grandes plagas epidémicas. La cuarentena permitió ensayar por primera vez la clasificación el espacio urbano de manera capilar en distritos, barrios, calles, viviendas... entre los que se establecía un exhaustivo control de los movimientos de las personas y mercancías. El combate contra la viruela no sólo introdujo los precedentes de la vacunación contemporánea, sino que aportó la noción de riesgo, es decir, la estimación de la probabilidad de enfermar en función de edades, condición social, distribución geográfica etc. Posibilitando sustentar las decisiones de gobierno en el conocimiento empírico de la realidad filtrado por herramienta estadística y la georreferenciación.

Esta innovación resultó esencial, porque cuando se produjeron a mediados del siglo XIX las terribles epidemias de cólera en Londres (Figura 1). La estrategia de acudir al conocimiento empírico de los hechos en vez basarse en las teorías dominantes - las miasmas- permitió determinar el origen de la enfermedad en las fuentes de agua contaminada y sentar las bases tanto de la epidemiología como del urbanismo contemporáneo, asociado para siempre a la gestión de las infraestructuras vitales.

A principios del siglo XX la evidencia empírica de la asociación entre las malas condiciones de habitabilidad urbana y la proliferación de la tuberculosis y otras enfermedades infecciosas inspiró un replanteamiento radical de la arquitectura y la ciudad sustentado en las nuevas tecnologías industriales. Somos todavía deudores en la revolución propiciada por el Bauhaus, los CIAM y los extensos experimentos de vivienda social del periodo de entreguerras en Centroeuropa

Desde mediados del siglo XX la mejora en los sistemas de abastecimiento y saneamiento de agua, programas de vacunación y disponibilidad de antibióticos han permitido minimizar el impacto de las enfermedades infecciosas en la ciudad. Alternativamente, ha ganado consenso una visión más amplia del papel de la arquitectura y el urbanismo en la consecución del bienestar físico y mental integral.

La aparición en las últimas décadas de nuevos patógenos como el HIV, SARS, H1N1, Ebola y la COVID19, ponen de manifiesto que la globalización al universalizar los procesos de urbanización y reducción de los ecosistemas naturales, potenciar las grandes migraciones transnacionales, la movilidad personal y el intercambio comercial a todas las escalas geográficas han acentuado la vulnerabilidad de las grandes aglomeraciones humanas. (Ali \& Keil, 2006; Matthew \& McDonald, 2006).

La emergencia sanitaria de la COViD19 parece devolvernos a las etapas sombrías de las cuarentenas. Una de las claves del éxito histórico de las ciudades -la proximidad de muchas personas- deviene en vulnerabilidad y la densidad es interpretada como un riesgo para la salud. Tendremos que hacer un enorme esfuerzo para aprender de esta experiencia nuevos modos de gestionar la ciudad y los sistemas de salud sin renunciar a la vida social (Friedman, 2020; Klaus, 2020; Centres of Excelence, 2020). La planificación del espacio -propia del planeamiento urbano convencional- habrá de incorporar a una visión prospectiva de la gestión social del tiempo para entender y gobernar la complejidad urbana contemporánea.

El traumático periodo de confinamiento domiciliario a escala global ha permitido visibilizar problemas urbanos latentes y suscitar nuevas prioridades de gestión (Bloomberg CityLab, 2020; Levine, 2020; Patino, 2020). En primer lugar, ha puesto en valor la dialéctica clásica entre espacio público y espacio privado sobre la que se basan las ciudades occidentales (Gehl, 2010) y fortalecido, paradójicamente, otra dimensión de la aglomeración humana: el sentido de comunidad. Por una parte, evidenciando las ventajas de los lugares donde la gente vive suficientemente cerca para acceder peatonalmente a

ACE, 15 (4:3) CC BY-ND 3.0 ES | UPC Barcelona, España | Hay que Defender la Ciudad: De la Distopía a la Ciudad 3 Abierta. DOI: http://dx.doi.org/10.5821/ace.15.43.9518 
los servicios que necesita y los beneficios colaterales de la reducción de la movilidad: la visible mejora de la calidad del aire y reducción de ruidos. Por otra evidenciando las graves contradicciones en la gestión urbana contemporánea: la inequidad en el acceso a los bienes públicos, la dimensión insuficiente o el diseño inadecuado del espacio público, la difícil convivencia entre la movilidad peatonal, el descanso y las actividades económicas, debido a la prioridad concedida al automóvil (Secchi, 2013).

Figura 1. Principales brotes epidémicos desde comienzos del siglo XIX

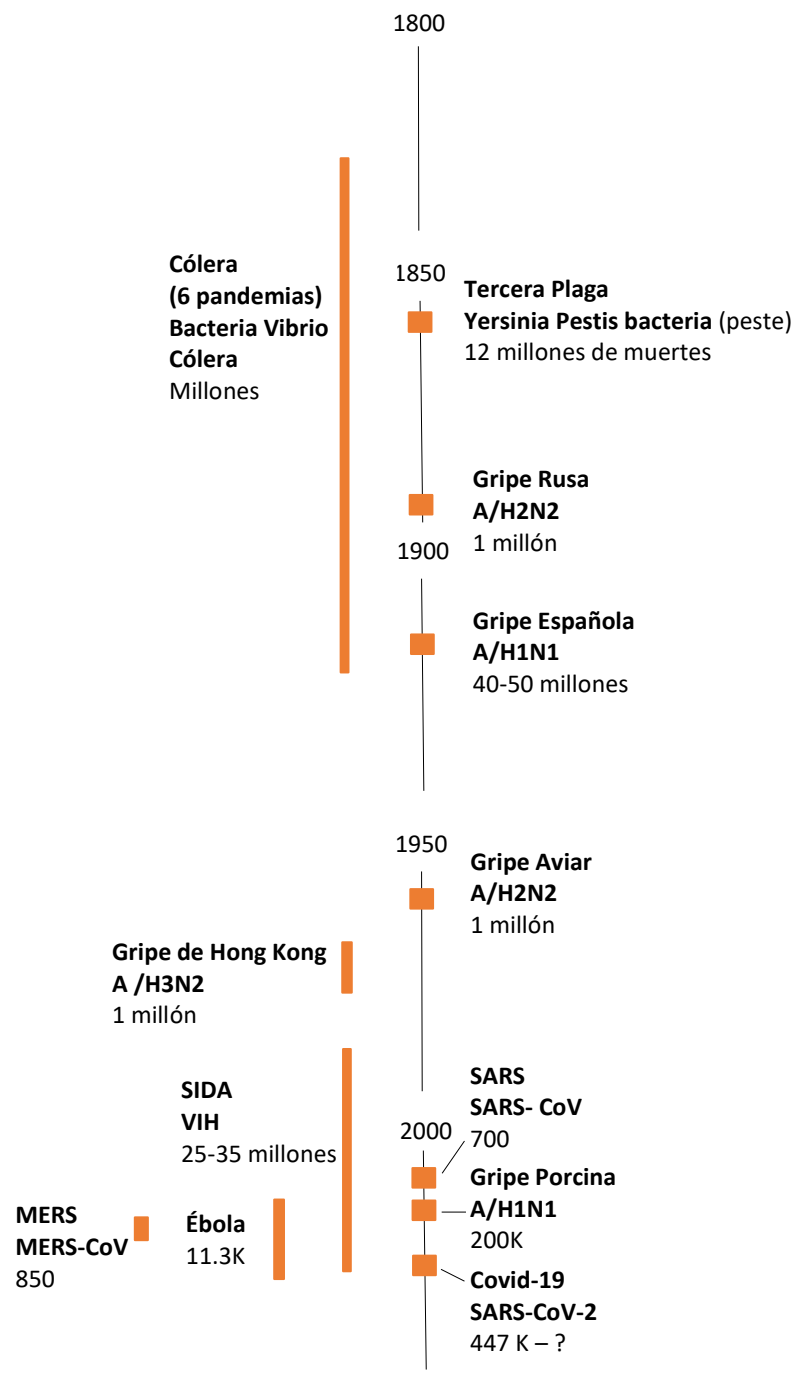

Fuente: R. Florida. This Is Not the End of Cities. CityLab, (19 de junio de 2020).

Adicionalmente, no deja de resultar paradójico que la experiencia insólita del confinamiento domiciliario haya puesto de nuevo en primer plano de actualidad la cuestión de la calidad residencial, al evidenciar la permanencia -a menudo invisible en los países desarrollados- de numerosas viviendas que no alcanzan los mínimos estándares de habitabilidad básica, así como la más grave paradoja del confinamiento domiciliario en la ciudad informal: ¿cómo puede confinarse en su vivienda quien carece de ella?.

Una de las más urgentes cuestiones que los urbanistas deben afrontar es la aparente contradicción entre la densificación entendida como tendencia a la limitación racional del consumo de territorio y

ACE, 15 (13) CC BY-ND 3.0 ES | UPC Barcelona, España | Hay que Defender la Ciudad: De la Distopía a la Ciudad 
estrategia fundamental en la sostenibilidad ambiental y lucha frente al cambio climático y la dispersión, la separación geográfica de los asentamientos, que en el contexto de la pandemia tiende a asociarse al distanciamiento social. El debate sobre la densidad tendrá que incorporar variables vinculadas al conocimiento, a la organización social, a la calidad de las infraestructuras vitales y al modo de gestión para entender y dar respuesta a cuestiones como el hacinamiento residencial, el déficit espacio público y la congestión los sistemas de transporte de las áreas urbanas desfavorecidas.

Una dimensión interesante de esta nueva realidad es la oposición entre los conceptos de aislamiento y cuarentena puesta ya de manifiesto ya durante la epidemia del SARS (la denominada neumonía atípica) en 2002 (Sample, 2012) En la primera fase contención de la pandemia del COVID19 se han contrastado dos modelos alternativos de gestión. En los países previamente afectados por el SARS la estrategia se ha basado en la biovigilancia o cuarentena selectiva, es decir la realización de tests masivos para identificar y aislar a las personas afectadas y trazar la evolución sintomática de sus contactos. Sin embargo, en Europa y América se han aplicado inicialmente las técnicas clásicas de la cuarentena a partir del confinamiento domiciliario de la totalidad de la población. Sólo cuando el brote ha logrado ser controlado se ha pasado también en estos países a aplicar la estrategia de biovigilancia (Pilmis \& Castel, 2020).

Por otra parte, la estrategia de la trazabilidad de los sujetos pone en cuestión la dialéctica entre los dominios de lo público y la esfera de la intimidad (Yong, 2020): sobre la que se sustenta el contrato social en Occidente. Plantea nuevas e interesantes preguntas sobre los niveles de la transparencia personal, en un contexto en el cual la transparencia en la gestión pública se ha consolidado como una exigencia ineludible de la gobernanza contemporánea y el alcance de la utilización de las herramientas de explotación de big data.

\section{Ciudades en cuarentena: del control administrativo del espacio urbano al control estadístico del riesgo}

Al contrario de la imagen literaria de la epidemia como catástrofe y anulación de cualquier orden establecido, la peste es el momento en el que la ciudad se militarizada, el poder se convierte en administración y la división por zonas de la población se lleva al extremo por un poder político cuyas ramificaciones capilares llegan sin parar hasta el centro de los individuos mismos, su tiempo, su vivienda, su localización, su cuerpo. Conforme a los reglamentos de cuarentena publicados desde finales Edad Media hasta principios del siglo XVIII la ciudad organiza y clasifica el espacio urbano en zonas: distritos, barrios, calles...entre las que se establece un exhaustivo control de los movimientos de las personas y mercancías. "Los centinelas tenían que estar siempre presentes en los sistemas de las calles, los inspectores de los barrios y distritos debiera hacer su inspección dos veces al día, de tal manera que nada de lo que pasaba en la ciudad podía escapar a su mirada." (Foucault, 1975, 1999, pág. 50-52)

De esta forma se sientan las bases del concepto de policía urbana. A finales del siglo XVIII la policía es la dimensión clave de la intervención pública en la administración e higiene general de la ciudad, comprendiendo: la planificación de las infraestructuras urbanas (alcantarillado, empedrado e iluminación); la gestión y mantenimiento de los nuevos servicios; la regulación de las servidumbres del espacio público en defensa de la calle frente a la invasión de obstáculos diversos y la regulación de las condiciones de seguridad frente al fuego de las actividades y construcciones.

ACE, 15 (4:3) CC BY-ND 3.0 ES | UPC Barcelona, España | Hay que Defender la Ciudad: De la Distopía a la Ciudad

Abierta. DOI: http://dx.doi.org/10.5821/ace.15.43.9518 
Desde la perspectiva actual, el control administrativo del espacio urbano, y a través de este de los flujos de las personas que lo habitan, puede parecer una cuestión evidente. No lo es tanto si pensamos en los barrios informales de las actuales megalópolis de los países emergentes y tampoco lo era en la ciudad medieval. En primer lugar, la calle desempeñaba en esta última un papel muy diferente al que adquiría en la época del transporte de los vehículos con ruedas. Como nos recuerda Lewis Mumford, tendemos a imaginar la calle como una hilera más o menos regular de casas situadas a ambos lados de un espacio público lineal. "Pero los terrenos medievales, menos regulares, las cosas sucedían a la inversa: grupos de artesanos o de edificios institucionales formaban barrios autónomos o islas sin que guardará relación la disposición de los edificios con las vías públicas. En el interior de estas islas, y a menudo afuera, los senderos señalaban las idas y venidas cotidianas de sus habitantes." (Mumford, 1961, pág. 375).

Tampoco se corresponde con la realidad histórica entender la ciudad medieval como una entidad unitaria y homogénea, confinada en el interior de un recinto amurallado. La morfología de las ciudades medievales adoptó formatos muy diversos, pero a los efectos de la organización administrativa es interesante recordar que la ciudad tendía a organizarse como un conjunto de microciudades con cierto grado de autonomía. Los barrios se agrupaban en torno a las parroquias, los mercados locales, el abastecimiento de agua, pozos o fuentes, lavaderos y frecuentemente congregaban a los artesanos de un mismo gremio. Cuando la ciudad crece los barrios tienden a mantener su identidad. La imagen de un espacio urbano sobrepoblado y sometido al azote de plagas, epidemias y crisis de escasez no se corresponde tanto con la ciudad medieval como con las primeras décadas de la ciudad industrial, tras las grandes migraciones rurales. En estos momentos en que tanto evocamos el concepto de ciudad próxima la idea tiene un valor sugestivo, pero desde el punto de vista del control centralizado de las epidemias suponía una dificultad añadida.

La Muerte Negra dejó un impacto muy severo en la demografía de las ciudades europeas, calculándose que sólo en el brote entre 1348 y 1349 llegaron a perder un tercio de su población, experimentando recurrentes catástrofes a lo largo de los siglos XVI y XVII. En términos humanos "la Florencia de Botticelli y Donatello era apenas una sombra de la bulliciosa ciudad de la baja Edad Media" (Hohenberg \& Lees, 1985, pág. 74). Aunque las pestes fueron las plagas de mayor impacto social, otras infecciones endémicas implicaron en su conjunto una mayor letalidad para la ciudad medieval. La historiografía contemporánea identifica el tifus, la disentería y la malaria entre la variedad de fiebres descritas por los contemporáneos. En general se trataba de enfermedades asociadas a la contaminación del agua, carencia de alcantarillado y alimentos en mal estado, afectando principalmente a los niños.

Otras dos enfermedades infecciosas acompañarían la transformación de las ciudades a lo largo de su historia más reciente: la viruela y la tuberculosis. Como veremos, la primera de ellas llegó a ser controlada gracias a la generalización de la vacunación, pero la tuberculosis prolongó su letalidad asociada a las deficientes condiciones de vida hasta bien entrado el siglo XX. En el inicio de la Era Moderna las ciudades europeas eran tan insalubres que sólo consiguieron mantener o incrementar su población gracias a los flujos continuos de emigrantes procedentes del exterior: campesinos expulsados de las áreas rurales, refugiados de las hambrunas o de las guerras o emigrantes laborales. La viruela es una enfermedad que se transmite por el aire sin particular incidencia sobre estratos determinados de la población, pero encontró en las ciudades sobrepobladas con casas y talleres escasamente ventilados el entorno favorable para prosperar. (Snowden, 2020) Durante los siglos XVII y XVIII la viruela se convirtió en una enfermedad endémica con eventuales brotes epidémicos. Su presencia continua llegó a ser considerada casi como un hecho normal sobre todo considerando que como otras enfermedades comunes afectaba sobre todo a la población infantil.

ACE, 15 (4.3) CC BY-ND 3.0 ES | UPC Barcelona, España | Hay que Defender la Ciudad: De la Distopía a la Ciudad

Abierta. DOI: http://dx.doi.org/10.5821/ace.15.43.9518 
A pesar de su importante impacto sobre la sociedad y la cultura, el combate contra la viruela no nos ha dejado un legado en términos de organización de la ciudad, como la peste, o de la arquitectura, como la tuberculosis, sino en el orden del conocimiento. Su combate no sólo introdujo los precedentes de la vacunación contemporánea, sino que aportó la noción de riesgo, es decir, la estimación de la probabilidad de enfermar en función de edades, condición social, distribución geográfica etc. Y, consecuentemente, la adopción de decisiones a partir al conocimiento empírico de la realidad filtrado por la herramienta estadística y la georreferenciación. Ello es debido a un hecho distintivo respecto a otras epidemias: la posibilidad de una temprana prevención de la enfermedad a través de la inoculación y la vacunación.

La inoculación o variolización era una vieja práctica popular que se basaba en la constatación de que contrariamente a la opinión médica ortodoxa la viruela claramente parecía ser contagiosa, pero que aquellos que se recuperaban de la enfermedad nunca la volvían a contraer. Surge así la idea de inducir una versión suave de la enfermedad para proteger a las personas de contraer una versión severa que amenazara su vida. (Snowden, 2020). Vacunación e inoculación eran prácticas impensables en términos de la racional médica de la época y, sin embargo, seguras y preventivas. El carácter eficaz y generalizable del variolización permitía pensar el fenómeno en términos de cálculo de probabilidades en base a las nuevas herramientas estadísticas disponibles. En esa medida ambas prácticas se beneficiaron de un soporte matemático que fue el mismo tiempo una suerte de factor de integración dentro de los campos de racionalidad admisibles y aceptados en la época.

Como es conocido, la vacunación se basa también en la observación empírica realizada por Edward Jenner de que en determinadas condiciones la viruela vacuna podía infectar a los seres humanos produciendo una versión benigna de la enfermedad que, sin embargo, también inmunizaba a estos de contraer la viruela, con menor riesgo que el variolización. De esta forma, se inició una nueva etapa en la salud pública y en el control de muchas otras enfermedades infecciosas. Desde la nueva mirada científica la viruela puede dejar de considerarse una enfermedad endémica, es decir consustancial de alguna manera con un país, una ciudad, un clima, un grupo humano y entenderse como una distribución de casos en una población delimitada en el tiempo y en el espacio. Este hecho permite calcular para que un individuo o un grupo individualizado el riesgo de contagio o de morbilidad y discriminar la probabilidad diferencial en función edades, condiciones, lugares, o medios que puedan aumentar o disminuir el peligro.

Adicionalmente, las epidemias pueden dejar de considerarse genéricamente para analizarse en clave de proceso y de crisis. Con el variolización la clave de su control ya no está como en la cuarentena y el aislamiento, basados en la distinción entre enfermos y no enfermos, sino en tomar en cuenta el conjunto de la población y analizar los coeficientes de morbilidad probables en función de cada edad, región, ciudad, barrios urbanos o profesiones (Foucault, 2008). El manejo estadístico de los conceptos de caso, riesgo, peligro, crisis sustentan las bases del gobierno moderno de las ciudades y de las emergencias sanitarias.

\section{La higiene publica y las infraestructuras vitales}

Esta innovación es esencial, porque cuando se produjeron a mediados del siglo XIX las terribles epidemias de cólera en París y Londres, la estrategia de acudir al conocimiento empírico de los hechos en vez basarse en nociones médicas o populares comúnmente aceptadas, pero nunca contrastadas - las miasmas- permitió hallar el origen de la enfermedad y sentar las bases tanto de la epidemiología como del urbanismo contemporáneo.

ACE, 15 (4:3) CC BY-ND 3.0 ES | UPC Barcelona, España | Hay que Defender la Ciudad: De la Distopía a la Ciudad 7

Abierta. DOI: http://dx.doi.org/10.5821/ace.15.43.9518 
Como es sabido Cerdá acuñó el concepto de urbanización "no sólo para indicar cualquier acto que tienda a agrupar la edificación y a regularizar su funcionamiento en el grupo ya formado sino también el conjunto de principios doctrinas y reglas que deben aplicarse para que la edificación y su agrupamiento, (...) Sirvan para fomentar su desarrollo y vigor y para acrecentar el bienestar individual, cuya suma forma la felicidad pública." (Cerdá, 1867 tomo uno, pág. 30-31)

A juicio de Sennett, los primeros urbanistas que buscaron esforzadamente abordar los nuevos problemas de salud pública planteados por la ciudad industrial fueron los ingenieros civiles que "llegaron a ser figuras heroicas en la generación de Cerdá porque trataron los asuntos de la salud pública en la ciudad más proactivamente que los médicos que no tenían verdaderas ideas sobre cómo prevenir la tuberculosis o las causas de las epidemias."(Sennett, 2015, pág. 22)

Fruto de este nuevo enfoque, abierto a la experiencia empírica y con una orientación pragmática en los propósitos, el anestesiólogo John Snow fue capaz identificar los orígenes de las epidemias de cólera en Londres desafiando las imprecisas doctrinas dominantes la Medicina de la época. Este episodio histórico ha generado una abundante literatura y matiza la minusvaloración de Sennett respecto del papel que jugaron los médicos en el impulso inicial de la reforma urbana.

La ingeniería de las nuevas infraestructuras subterráneas tuvo que afrontar el problema de la invisibilidad. la representación planimétrica tradicional de la ciudad no proporcionaba las técnicas de representación que los ingenieros necesitaban. Esta limitación impedía concebir la ingeniería civil como una ciencia exacta y empujó a los pioneros como Cerdá a adoptar una posición heurística, sustentada sobre el conocimiento racional de los hechos, pero atenta a aprender de los aciertos y errores de su propia práctica. "Así que, después de haber dado a conocer la urbanización en su conjunto me consagre al estudio de sus detalles, trabajo anatómico en que, introduciendo el escalpelo hasta lo más íntimo y recóndito del organismo urbano y social se consigue sorprender viva en acción la causa originaria, el germen fecundo de la grave enfermedad que corroe las entrañas de la humanidad" (Cerdá, 1867, tomo uno, pág. 16-17)

El miedo popular al cólera venía amplificado por la teoría miasmática en su transmisión. "La enfermedad era tanto invisible como omnipresente: Se filtraba por los agujeros de las hondonadas y se alzaba en la niebla amarillenta a lo largo del Támesis” (Johnson, 2006, pág. 86). Basándose en sus conocimientos de los gases, el Dr. Snow, 1849 se apartó de esta idea razonando que de ser cierta los pacientes debían presentar síntomas respiratorios y no el característico síndrome diarreico agudo del cólera.

Analizando al registro de funciones Snow observó que los distritos de la zona sur de Londres que se abastecían aguas abajo del Támesis arrojaban una mayor tasa de mortalidad que los distritos de otras zonas que se abastecían de aguas menos contaminadas captadas aguas arriba del río. Es la observación empírica despojada de apriorismos dogmáticos la que le conduce a cuestionar la creencia dominante y formular una hipótesis alternativa conforme a la cual el origen del cólera procede del agua que tendría que ser portadora de algún tipo de contaminación, o materia mórbida, en sus propias palabras. Un nuevo brote de cólera en 1853-54 que costó más de 10.000 vidas, fue particularmente virulento en el barrio de Golden Square, abastecido por una bomba de agua de uso público ubicada en Broad Street, pero brindó la oportunidad de confirmar su teoría. Es interesante destacar, desde la perspectiva actual, el coraje necesario para investigar la enfermedad desafiando la creencia general de que la mera respiración en el entorno de un brote suponía un riesgo de muerte. Equipado solo con su razonamiento Snow estima que si el cólera estaba en el agua aventurarse en el vecindario de Golden Square en el apogeo de la epidemia no suponía una amenaza grave siempre y cuando se estuviera de beber del agua de la bomba durante sus visitas.

ACE, 15 (4.3) CC BY-ND 3.0 ES | UPC Barcelona, España | Hay que Defender la Ciudad: De la Distopía a la Ciudad 8

Abierta. DOI: http://dx.doi.org/10.5821/ace.15.43.9518 
John Snow apeló, de nuevo, a la observación empírica: registrando los nombres y direcciones de las personas fallecidas en el área, visitando sus viviendas, preguntando el origen de su abastecimiento de agua potable para elaborar finalmente un plano en el que se grafían los fallecimientos registrados en cada inmueble. Esto permitió relacionarlos intuitivamente con la distancia a la bomba de agua.

El estudio del subsuelo en torno a la bomba de agua evidenció su proximidad con la red de saneamiento en mal estado y por tanto el origen de la probable contaminación y logró convencer a las autoridades de la necesidad de su inutilización. El resultado fue la contención inmediata del brote, a pesar de las protestas de los vecinos por la incomodidad generada tras el cierre de su habitual suministro de agua.

Pocos años después Louis Pasteur presentaría en la Sorbona sus descubrimientos sobre los microorganismos presentes en el ambiente, archivando para la historia las teorías de la generación espontánea y las miasmas como origen de las enfermedades infecciosas. Y en 1890 Robert Koch aislaría el vibrio cholerae, la materia mórbida que Snow afirmaba presente en el agua contaminada de la bomba de Broad Street (Figura 2).

Figura 2. John Snow. Plano de las defunciones en el barrio de Golden Square, abastecido por la bomba de agua de uso público ubicada en Broad Street

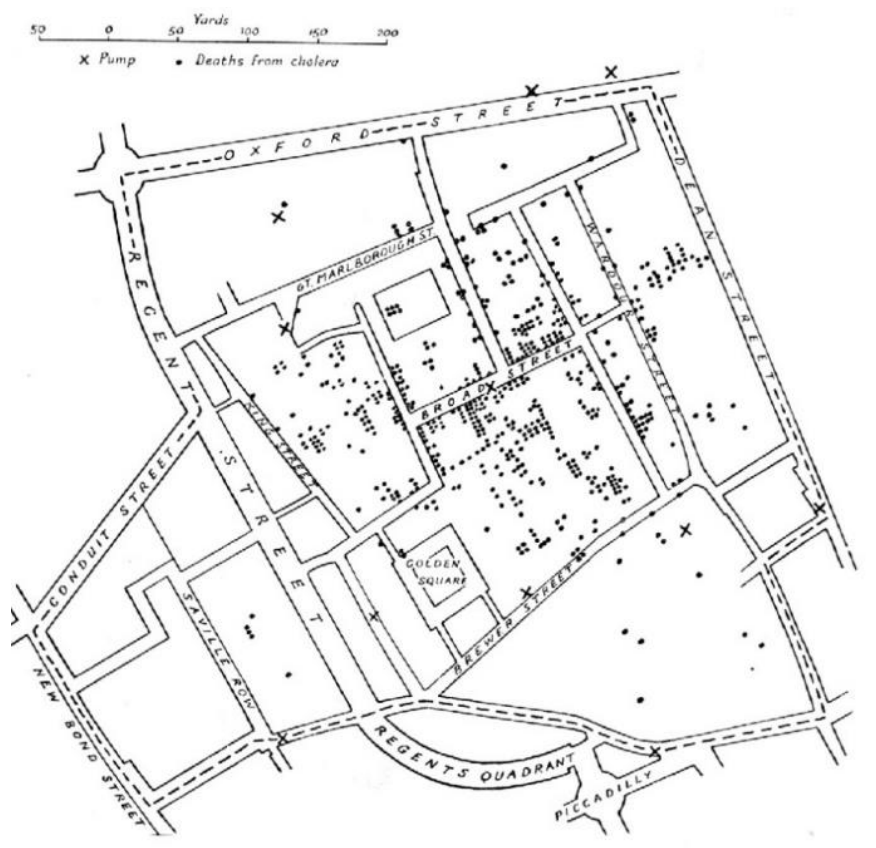

Fuente: College of Physicians of Philadelphia

El plano de Snow, en línea con los precedentes de Richard Grainger y Edmund Chadwick (Koch, 2005) constituye uno de los primeros testimonios documentales tanto de los orígenes de la epidemiología moderna, como de la nueva disciplina urbanística, asociada para siempre a la gestión de las infraestructuras vitales de la mano del ingeniero Joseph Bazalgette (Figura 3), proyectista de la emblemática Red de Saneamiento de Londres, que permitió la recogida y depuración de las aguas residuales de la ciudad y la prevención de futuros brotes de cólera (Jackson, 2014). Después de Bazalgette el urbanismo no fue nunca más entendido como la mera ordenación geométrica del suelo desde criterios compositivos, sino como el saber practico de la organización funcional de la ciudad comenzando por sus infraestructuras vitales, tal como defendió Cerda en su Teoría General de la Urbanización.

ACE, 15 (4.3) CC BY-ND 3.0 ES | UPC Barcelona, España | Hay que Defender la Ciudad: De la Distopía a la Ciudad 9 Abierta. DOI: http://dx.doi.org/10.5821/ace.15.43.9518 
Figura 3. Joseph Bazalgette en el colector dl desagüe del Norte de Londres en construcción bajo la estación de bombeo Abbey Mills

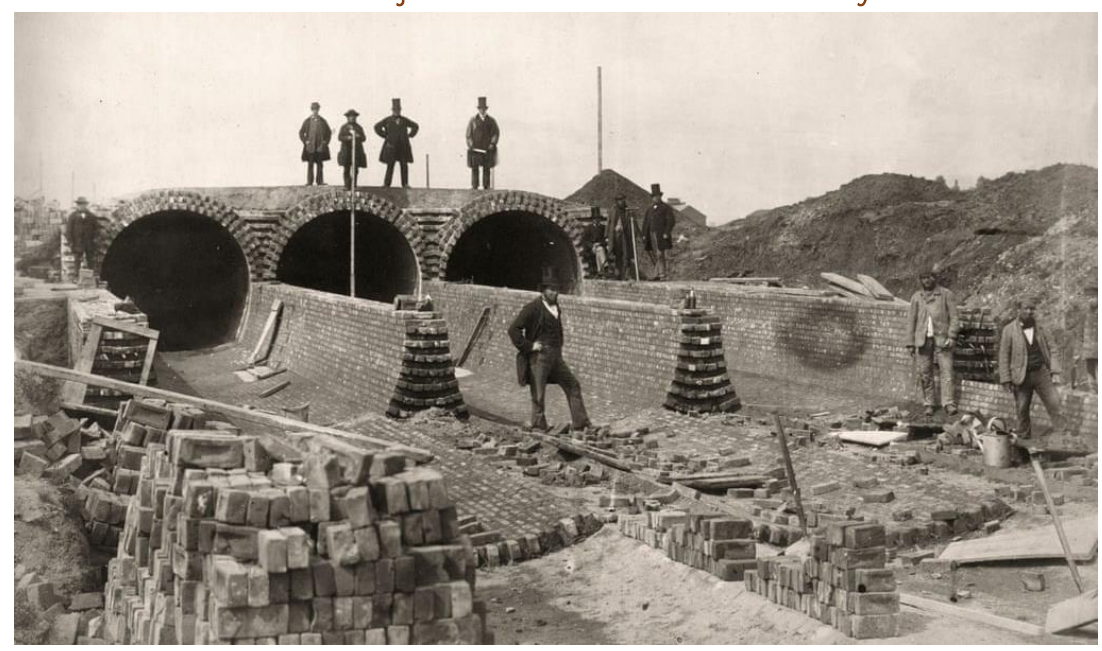

Fuente: Otto Herschan.

\section{La ciudad enferma}

El apogeo de la urbanización a finales del siglo XIX y principios de siglo XX suscitó la demonización de la densidad, entendida como el origen de la enfermedad, la pobreza y la inmoralidad. Para muchos reformadores de Thomas Jefferson a Olmsted o Burham los males urbanos -el vicio y la insalubridadse entienden estrechamente vinculados al entorno físico de las ciudades y ajenos a las condiciones del sistema económico que había generado la ciudad industrial (Kling, 2020). Lo expresaba con gran exactitud el Health of Towns Committee británico en 1840: "Además de los males físicos debidos a las malas condiciones de habitabilidad, también la inmoralidad de las clases pobres depende de las mismas causas" (Evans, 1980, pág. 269. Véase también Chadwick, 1842).

La concepción liberal de la propiedad, que se consolida en Europa y Norteamérica en paralelo al proceso de industrialización, se sustenta sobre la base de la demarcación de los territorios de lo público y lo privado. Durante mucho tiempo la edificación se consideraba referida en exclusiva a esta última esfera, en la que el propietario gozaba de plena libertad y, por tanto, se encontraba al amparo de la intervención administrativa. Esta situación sufrirá una mutación radical cuando el desarrollo de los conceptos de higiene publica evidencie los resultados abusivos de la carencia de límites objetivos a la facultad de edificar (Bassols, 1973).

A lo largo de la segunda mitad del XIX se alzan también en España numerosas voces denunciando el estado de abandono y malas condiciones higiénicas en que se encuentran las edificaciones del Casco y tanto Castro como Fernández de los Ríos, comparan irónicamente el importante desarrollo de la regulación municipal de materias tales como el ornato o las actividades clasificadas, en relación con la escasez de regulaciones sobre el tema. Tras las fachadas más modernas de las construcciones del Ensanche se esconden situaciones intolerables tales como viviendas en sótanos y buhardillas, viviendas interiores entre patios sombríos, hacinamiento, falta de superficie mínima en dormitorios. López Sallaberry (1901, pág. 12) señala que, en la zona de Preciados en el Centro de Madrid, hoy una emblemática zona comercial: "Sobre $20 \mathrm{~m} 2$ de suelo y volumen de aire insuficiente permanecía largas horas una familia compuesta por 5 o 6 individuos que, aunque tuviesen temperamento sano y fuerte, no tardaban en perder la salud y entonces la existencia de un sólo enfermo en una atmósfera pobre en oxígeno precipitaba la muerte del enfermo y la presencia de nuevos casos en los que le rodeaban."

ACE, 15 (4:3) CC BY-ND 3.0 ES | UPC Barcelona, España | Hay que Defender la Ciudad: De la Distopía a la Ciudad 10 Abierta. DOI: http://dx.doi.org/10.5821/ace.15.43.9518 
Las condiciones urbanas son también consideradas deficientes. Los Congresos Higienistas de 1882 señalan como asociados a la mortalidad, además del clima de Madrid, la densidad elevada, la altura de los edificios excesiva (y por tanto las largas escaleras), las malas condiciones de las alcantarillas y retretes, la permeabilidad excesiva del suelo y la falta de condiciones de mercados y hospitales. Si bien son razones pronto superadas por los progresos en el conocimiento científico, no dejaran de influir en el legislador. En este mismo periodo la ocupación de los Ensanches de las ciudades españolas se desarrollaba muy lentamente, debido a la precariedad de los instrumentos municipales de gestión y financiación de las obras y encarecimiento y consecuente retención especulativa del suelo. Por lo que en gran medida fracasaron en su vocación inicial de acoger e impulsar el desarrollo poblacional de las grandes ciudades. Paralelamente, los centros tradicionales de las principales ciudades españolas iniciaron un proceso de híper densificación del parcelario construido, que acabó con la porosidad de las tramas urbanas y caseríos preindustriales, consolidando en muchos casos un hacinamiento insoportable que ha llegado hasta nuestros días (Hauser, 1902; Urteaga, 1980 y 1985)

El proceso de densificación de los centros fue estimulado desde la normativa urbanística que eludió aplicar a la ciudad tradicional las regulaciones más higiénicas e innovadoras en materia de limitación de alturas y amplitud de patios introducidas en los planes de ensanche. Para completar el escenario, comenzó a formarse con extraordinaria vitalidad una nueva ciudad situada fuera de los límites físicos de la ciudad planeada -y por tanto fuera del alcance las ordenanzas municipales y los planes de ensanche- gravitando sobre las principales carreteras y caminos radiales de comunicación interurbana: el denominado Extrarradio. Consolidando la morfología característica dividida en tres coronas concéntricas: centro histórico, ensanche reticulado y extrarradio espontáneo qué caracterizó a las grandes ciudades españolas hasta el surgimiento de los grandes polígonos de edificación abierta en la mitad del siglo XX y las grandes extensiones suburbio de baja densidad a finales de siglo.

Los orígenes de la legislación urbanística en Inglaterra Francia y España no proceden de las Leyes expropiatorias, que como indica Leonardo Benévolo,1963, pronto se especializaron al adoptar un enfoque sectorial incapaz de diagnosticar las relaciones y vínculos entre los sectores propio de la visión holística del planeamiento. Sería la evidencia del impacto sobre la salud pública del desorden y hacinamiento de las ciudades industriales las que orientaría los primeros intentos serios de abordar el problema urbano en su conjunto es decir desde la perspectiva higiénica de la habitación y de las infraestructuras sanitarias (figura 4). La legislación de Londres de 1844, por ejemplo, definió por primera vez requisitos higiénicos mínimos para las casas de arrendamientos y prohibió destinar a vivienda los locales subterráneos, adelantando los criterios de la primera Public Health Act de 1847.

Figura 4. Londres durante la epidemia de gripe de 1918

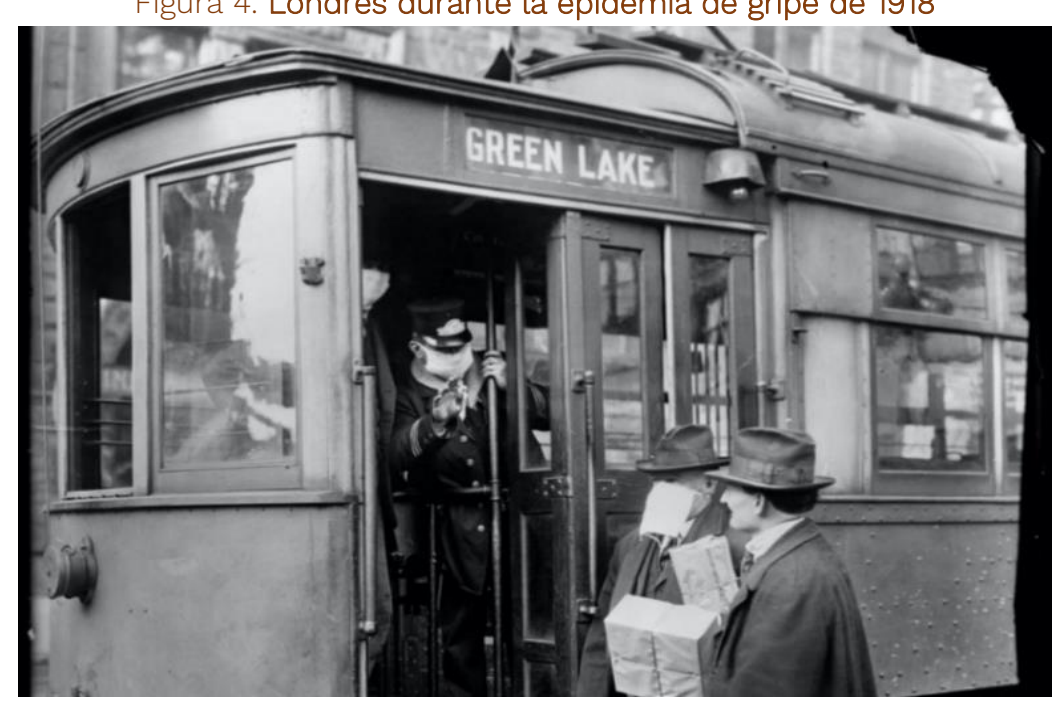

Fuente: Dominio público.

ACE, 15 (4:3) CC BY-ND 3.0 ES | UPC Barcelona, España | Hay que Defender la Ciudad: De la Distopía a la Ciudad

Abierta. DOI: http://dx.doi.org/10.5821/ace.15.43.9518 
El recrudecimiento de la tuberculosis en el mundo industrializado durante siglos ha planteado en los historiadores y epidemiólogos la cuestión sobre si se trata de una epidemia o más bien de una enfermedad endémica. Como señala Snowden, desde el punto de vista de una sola generación la enfermedad tiene una presencia continua año tras año sin los estallidos y flujos evolutivos de las epidemias clásicas por lo que llega a ser percibida como un estado de normalidad, semejante al antes descrito en relación con la viruela. Esta percepción se ve favorecida por el hecho de que la infección se transmite despacio persona a persona, tras un prolongado periodo de contacto y de latencia asintomática. Sin embargo, desde la perspectiva de la larga duración la tuberculosis se ajusta al modelo epidémico en cámara Lenta, persistiendo durante siglos en un determinado lugar para más tarde retirarse gradual y misteriosamente. (Snowden, 2020)

Pueden identificarse dos etapas en la historia moderna de la tuberculosis: antes y después de que el descubrimiento por Robert Koch en 1872 del Mycobacterium tuberculosis avalara la teoría de los gérmenes y, por tanto, su carácter contagioso. A partir del momento la tisis romántica dejó de ser una afección hereditaria, glamourosa que afectaba a las élites creativas para entenderse como una enfermedad peligrosa y estigmatizadora asociada a la pobreza y a la carencia de higiene.

Figura 5. Alvar Aalto, sanatorio antituberculoso de Paimio 1932. Terrazas diseñadas para favorecer la cura a través del aire puro y los baños de sol

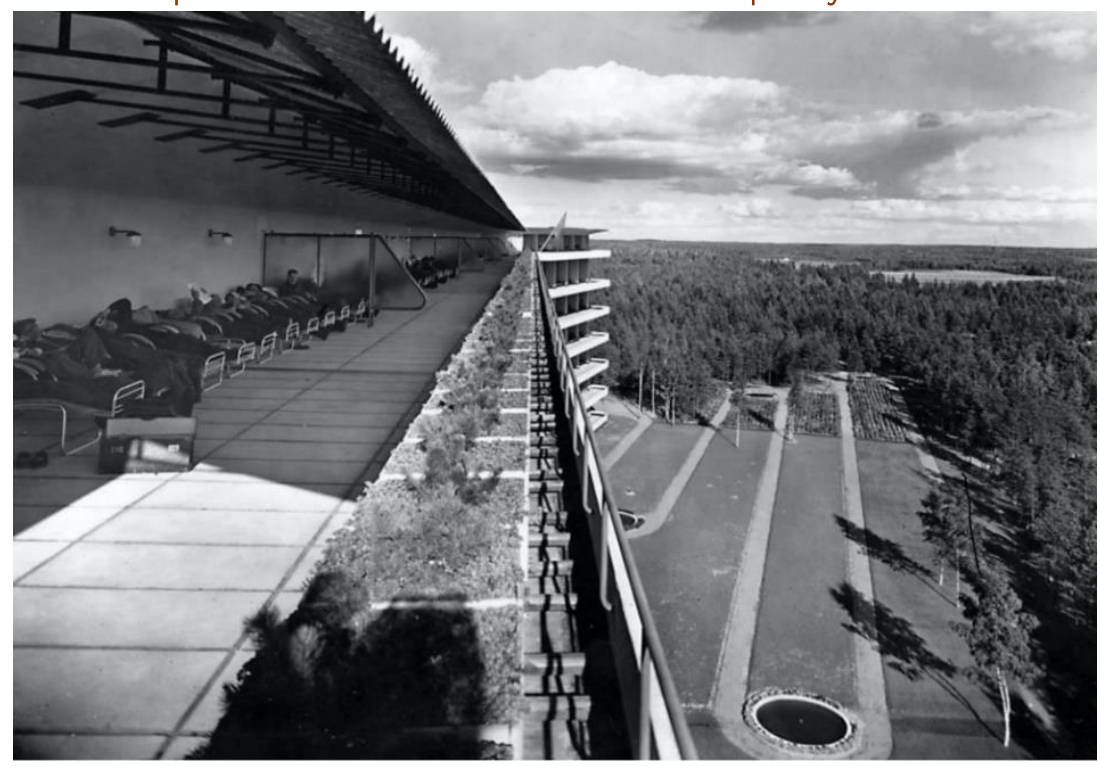

Fuente: Museo Alvar Aalto.

No sólo influye en este cambio de actitud la consolidación de la doctrina médica del contagionismo, sino también la disposición de estudios epidemiológicos y estadísticos sobre la evolución de la enfermedad y su perfil social. El Congreso Internacional de Ciencias Médicas celebrado en Barcelona en 1888 estableció la íntima relación entre las condiciones sanitarias de las viviendas y las enfermedades de los individuos que las albergan, sugiriendo así un nuevo campo de colaboración entre arquitectos, ingenieros y médicos. El discurso higienista tomará la vivienda como objeto de reflexión y analizará el papel de cada uno de sus elementos en la salud y bienestar humano, abriendo un nuevo ámbito a la reflexión arquitectónica, así como la regulación normativa. Además de la preocupación por los diversos materiales empleados en la construcción, aislamientos térmicos y acústicos, humedades. Aparecen también temas directamente relacionados con la tipología de la vivienda y su distribución funcional, cubicaje de las habitaciones, ventilación, iluminación.... así como relacionados con las instalaciones higiénicas mínimas.

ACE, 15 (4:3) CC BY-ND 3.0 ES | UPC Barcelona, España | Hay que Defender la Ciudad: De la Distopía a la Ciudad

Abierta. DOI: http://dx.doi.org/10.5821/ace.15.43.9518 
En las primeras décadas del siglo XX el estudio científico de las condiciones de vida y vivienda permitió acreditar la asociación entre las malas condiciones de habitabilidad urbana y la proliferación de la tuberculosis y otras enfermedades infecciosas. En Hamburgo se constató en 1922 que las tasas de mortalidad de la tuberculosis eran inversamente proporcionales a la cantidad de impuestos pagados, es decir a la renta de las familias. Estudios semejantes se realizaron en París, New York o Madrid poniendo siempre de manifiesto la vinculación entre tuberculosis y pobreza. Inspirando décadas más tarde, un replanteamiento radical de la arquitectura y la ciudad sustentado en las nuevas tecnologías industriales: el vidrio y el hormigón que permitirían abrir grandes huecos y permitir que el aire y el sol entrará al último rincón de la vivienda higiénica y saludable (Giedion, 1948).

En las conclusiones del estudio pionero sobre la vivienda insalubre en Madrid realizado en 1914 por el doctor César Chicote (Figura 6) se proponían tres grandes grupos de medidas, todas ellas de carácter social y político: mejorar la educación de la población general en materia de higiene, mejorar los servicios estadísticos municipales y de control sanitario y robustecimiento de la autoridad municipal. Finalmente, la intervención estatal en la materia dio el tema el impulso definitivo.

Figura 6. La mortalidad en los barrios de Madrid

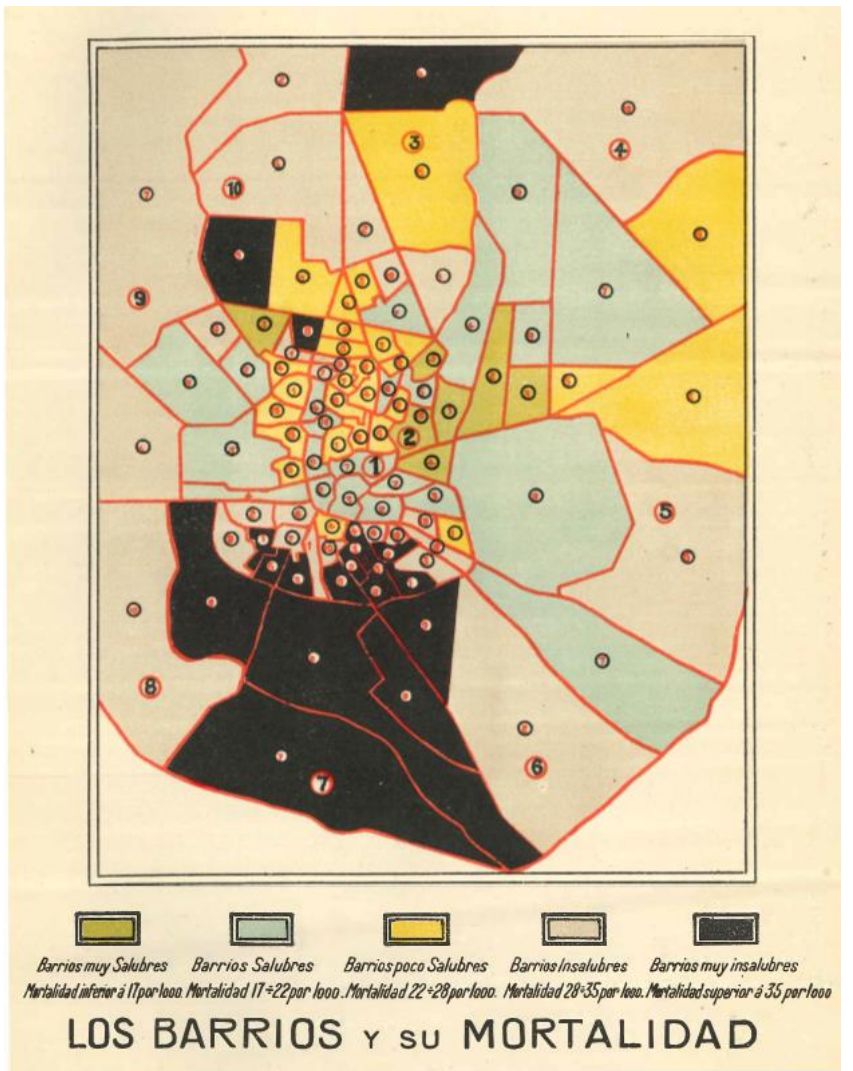

Fuente: César Chicote: La vivienda insalubre en Madrid, 1914.

El Reglamento de sanidad de 1925 estableció que toda habitación había de ser seca ventilada, limpia y espaciosa. La falta o insuficiencia de cualquiera de estas condiciones entiende constituye causa de insalubridad que habrá de ser subsanada conforme a las prescripciones o medios que la técnica de la construcción ofrece. En cuanto al programa de vivienda mínimo se fija que en interés de la higiene y la moral la vivienda de una familia con hijos deberá constar de cocina, baño independiente, habitaciones separadas para padres hijos e hijas y habitación de estancia común, todas con la ubicación y ventilación prescritas por la higiene. Atribuyendo a los inspectores municipales de sanidad la vigilancia contra el hacinamiento y las excesivas densidades de vivienda. 
La RO de 29 de febrero de 1944 refundió todas las regulaciones precedentes sobre vivienda precisando la composición y dimensiones mínimas, condiciones de ventilación, ascensores etc. En cuanto a distribución no se regulaban preceptos análogos desde las Leyes de Casas Baratas. Más significativo es su vigencia ininterrumpida hasta el momento en que las Comunidades Autónomas han ejercido sus competencias exclusivas en la materia han generado nuevas regulaciones. Lamentablemente muy poco innovadoras respecto a los criterios y estándares de 1944. No deja de resultar paradójico que la experiencia insólita del confinamiento domiciliario haya puesto de nuevo en primer plano de actualidad esta última cuestión, al evidenciar la permanencia invisible de numerosas viviendas que no alcanzan los mínimos criterios de habitabilidad básica. Se hace ineludible activar las acciones de rehabilitación y renovación del parque residencial, principalmente en los centros históricos, actualizar las normativas de habitabilidad básica de la vivienda y excluir del mercado residencial y turístico aquellas viviendas que no los alcancen.

\section{Confinamiento y vivienda mínima}

En las últimas décadas ha ganado consenso una visión más amplia del papel de la arquitectura y el urbanismo en la consecución del bienestar físico y mental integral. Superada la amenaza de las enfermedades infecciosas, las prioridades se orientan a la formulación de estrategias para combatir las patologías predominantes en las sociedades urbanas contemporáneas: las enfermedades cardiovasculares, respiratorias, obesidad y cáncer, asociadas a los modos de vida sedentarios, alimentación y mala calidad del aire. Sin olvidar el impacto que el cambio climático pueda significar sobre la salud humana (Barton \& Tsouru, 2010; Barton, 2017).

La actual emergencia sanitaria parece devolvernos a las etapas sombrías de las epidemias cuando la calle, la plaza y el mercado eran un peligro. Pero no hay duda de que la ciudad del bienestar (Hall, 2014), sustentada sobre un replanteamiento de las relaciones entre los habitantes, el medio urbano y la naturaleza es un paradigma llamado a perdurar e imponerse sobre las emergencias temporales. En los años 1920s una vanguardia internacional de profesionales promovió una renovación radical de la arquitectura y el urbanismo. Es frecuente interpretar retrospectivamente su legado en términos de eficiencia funcional, nuevos materiales (cristal, acero, hormigón armado), nuevas tecnologías de construcción y la adopción de la estética maquinista. Beatriz Colomina sostiene que la "arquitectura moderna se configuró bajo el dominio de la obsesión médica de su época: la tuberculosis: y la tecnología con esta asociada: los rayos X" (Colomina, 2019, pág. 10).

Hasta que se descubre un tratamiento efectivo para la tuberculosis la enfermedad se trataba principalmente con arquitectura (Zeiba, 2020). Las innovaciones médicas en su tratamiento: las terrazas soleadas y abiertas al aire puro y más tarde los rayos $X$ tienen su primera síntesis constructiva en la nueva tipología del sanatorio antituberculoso (Figura 5). En la nueva arquitectura hospitalaria de los inicios del siglo XX colaboran médicos, jóvenes arquitectos e ingenieros desde una perspectiva muy alejada de la retórica ornamental en la que se desenvolvía la arquitectura académica. La nueva racionalidad de la arquitectura inspiró en la arquitectura doméstica principios como la interpenetración entre el exterior y el interior, las terrazas abiertas, los grandes vanos de cristal, las paredes blancas, las líneas claras y la ausencia de ornamento. Estableciendo "una íntima, incluso romántica, relación entre un nuevo tipo de imagen médica y un nuevo tipo de espacio" que con el tiempo se convertiría en el emblema de la nueva Arquitectura. Pero este proceso también se puede entender como sinergia entre un pensamiento higienista de largo aliento y una respuesta técnica en términos de arquitectura y organización urbana, que nos recuerda la concurrencia entre la nueva epidemiología y la ingeniería sanitaria para superar las enfermedades infecciosas transmitidas por el agua en el siglo XIX.

El confinamiento domiciliario de la totalidad de la población adoptado en la mayor parte de los países afectados por la epidemia del COVID19 ha puesto de actualidad un siglo después las cuestiones

ACE, 15 (4:3) CC BY-ND 3.0 ES | UPC Barcelona, España | Hay que Defender la Ciudad: De la Distopía a la Ciudad 14 Abierta. DOI: http://dx.doi.org/10.5821/ace.15.43.9518 
relativas a los mínimos estándares de habitabilidad residencial aceptables en las sociedades desarrolladas, y la cuestión mucho más dramática de la carencia de vivienda digna en muchas metrópolis en los países emergentes, sintetizada en la dramática constatación ¿cómo puede confinarse en su vivienda el que no tiene vivienda?

Las viviendas del confinamiento se han tenido que transformar en oficinas, escuelas y patios de juego. Además de entornos eventuales de la cuarentena entre convivientes contagiados. En las viviendas más recientes se evidenciado la carencia de la relación con el exterior que proporcionaban las terrazas, tanto tradicionales como vinculadas a la arquitectura moderna y la holgura y ventilación en los espacios comunes. Muchas de estas deficiencias podrán ser corregidas desde los planes municipales primando en términos de edificabilidad la incorporación de terrazas abiertas y balcones en fachada, vestíbulos y elevadores más amplios, espacio para bicicletas y azoteas verdes utilizables.

Figura7. Mapa de tasa de incidencia acumulada de coronavirus a 23 de junio de 2020

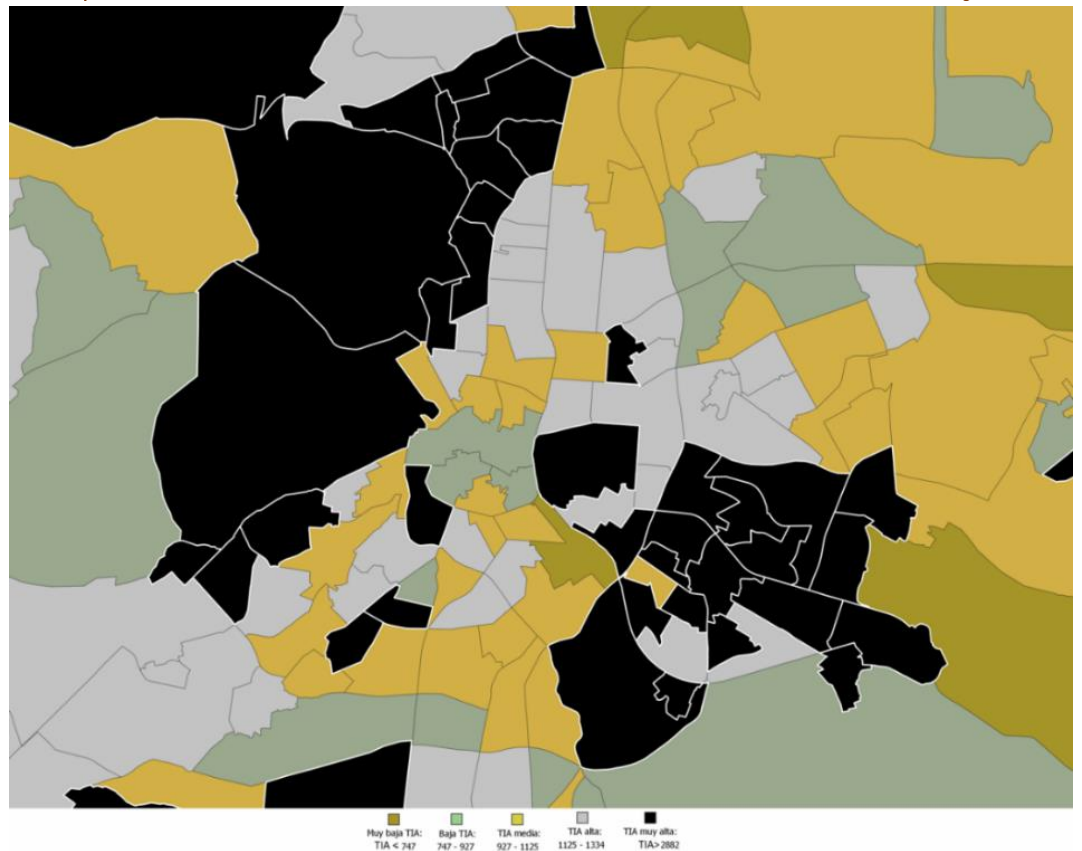

Representación por quintiles ajustada al conjunto de valores registrados en las zonas sanitarias de la Comunidad de Madrid. https://www.comunidad.madrid/gobierno/actualidad/datos-coronavirus Fuente: Javier Barros y José María Ezquiaga.

La Figura 7 muestra, para el caso de la Ciudad de Madrid, la relación entre la superficie construida en m2 en edificios de uso predominante residencial por persona y por hogar y permite apreciar la consolidación a largo décadas del patrón espacial de localización en función del nivel de renta entre Norte y Noroeste y Sur y Sureste. Sin embargo, la comparación entre este plano y el elaborado un siglo antes permite apreciar cambios sustanciales.

A pesar de que las áreas sanitarias integran en determinados casos barrios con población niveles de renta muy diversos puede apreciarse que, debido a la reducción de población residente en las áreas centrales -inducida por la multiplicación de usos terciarios y más recientemente por la multiplicación de las viviendas turísticas- tanto el estándar de superficie/habitante como la incidencia geográfica de la Covid19 no se corresponden con las áreas de mayor mortalidad identificadas por César Chicote en 1914 sino que se han desplazado a las inmediatas coronas periféricas. Asimismo, se verifica la mayor transversalidad social de la infección, también contrastada en otras ciudades donde la variable de intensidad de flujos de intercambio ha sido tanto o más significativa que las condiciones de hacinamiento domiciliario.

ACE, 15 (4:3) CC BY-ND 3.0 ES | UPC Barcelona, España | Hay que Defender la Ciudad: De la Distopía a la Ciudad 15 Abierta. DOI: http://dx.doi.org/10.5821/ace.15.43.9518 


\section{ACE Architecture, City and Environment}

E-ISSN 1886-480:

Las viviendas más antiguas no sólo se han demostrado incómodas por su reducido tamaño o difícil partición en casos de cuarentena entre convivientes, sino que muchos casos son manifiestamente una amenaza para la salud de sus habitantes. (Figura 8)

Figura.8 Mapa relación entre la superficie construida en m2 en edificios de uso predominante residencial por persona

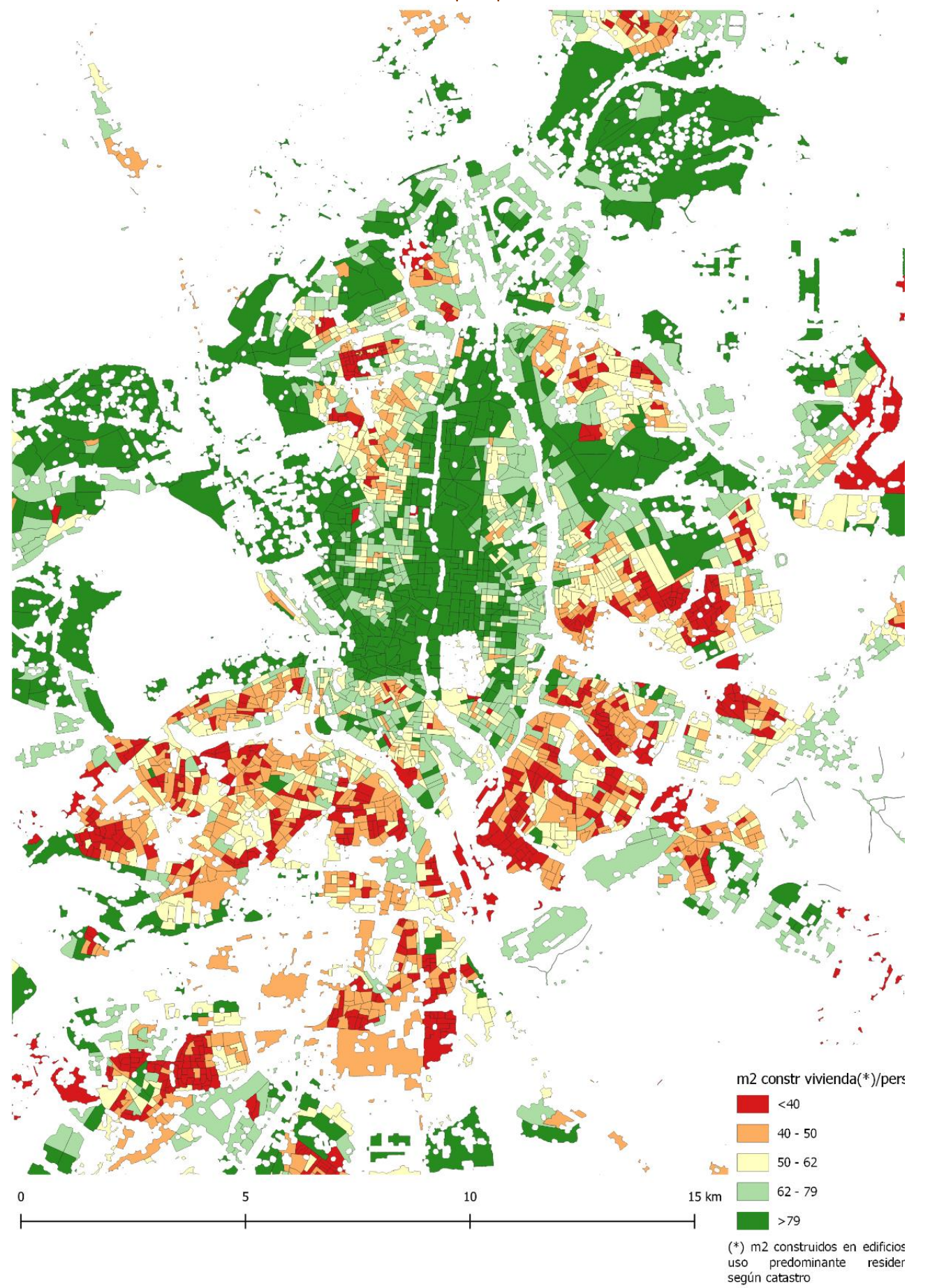

Fuente: Javier Barros y José María Ezquiaga. https://www.ine.es/experimental/atlas/exp atlas tab.htm; www.sedecatastro.gob.es.

ACE, 15 (4.3) CC BY-ND 3.0 ES | UPC Barcelona, España | Hay que Defender la Ciudad: De la Distopía a la Ciudad 16 Abierta. DOI: http://dx.doi.org/10.5821/ace.15.43.9518 
Tabla 1. Normativa de condiciones mínimas de habitabilidad para vivienda existente en la legislación española

\begin{tabular}{|c|c|c|c|c|c|c|}
\hline & NNEL ESTATAL & CATALUÑa & NAVARRA & PAISVASCO & LA RIOJA & AYTO. MADRID [] \\
\hline Normativa & $\begin{array}{l}\text { Orden Mnisterial de Viviencta de } \\
29 \text { de febrero de } 1944\end{array}$ & 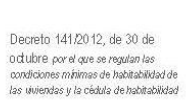 & 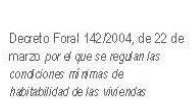 & 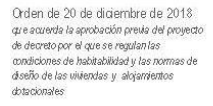 & 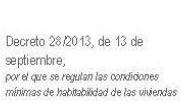 & $\begin{array}{l}\text { Normas Uthanisticicas Plan } \\
\text { General de Ordenacion nutbana } \\
\text { de Madind } 1997\end{array}$ \\
\hline \multirow[t]{2}{*}{$\begin{array}{l}\text { Tipo de viviendas } \\
\text { afectadas }\end{array}$} & Toda clase de vivienda & $\begin{array}{l}\text { Viviendas existentes smerioress } \\
1994\end{array}$ & Viviendas existentes & Vivendas existentes & $\begin{array}{l}\text { Viviendas existentes ameriveses } \\
\text { 19999 }\end{array}$ & Toda clase de vivienda \\
\hline & \multicolumn{6}{|c|}{ Compasición minima de la vivienda } \\
\hline$N^{0}$ min.de piezas & $\begin{array}{l}1 \text { codina-comedor } \\
1 \text { dormentorio doble } \\
1 \text { aseo }\end{array}$ & $\begin{array}{l}1 \text { estancia } \\
1 \text { cocina (ritegradaho) } \\
1 \text { aseo }\end{array}$ & $\begin{array}{l}1 \text { estar } \\
1 \text { cocina (ritegradalno) } \\
1 \text { dorminonio } \\
1 \text { assoo }\end{array}$ & 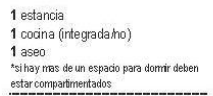 & $\begin{array}{l}1 \text { estancia } \\
1 \text { cocina (integradaho) } \\
1 \text { aseo }\end{array}$ & $\begin{array}{l}\text { 1estancia } \\
\text { 1 cocina antegradaho) } \\
1 \text { aseo }\end{array}$ \\
\hline \multirow[t]{2}{*}{ Nomin de baños } & 1 aseo & 1 aseo & 1 aseo & 1 aseo & 1 aseo & 1 aæe \\
\hline & \multicolumn{6}{|c|}{ Superficies útiliesy dimensiones minimas de las piezas } \\
\hline Total vivienda & 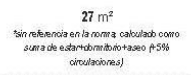 & 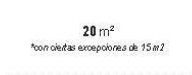 & 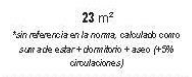 & $25 \mathrm{~m}^{2}$ & $25 \mathrm{~m}^{2}$ & $\begin{array}{l}36 \mathrm{~m}^{2} \text { en viviendas } \\
25 \mathrm{~m}^{2} \text { en estudios }\end{array}$ \\
\hline $\begin{array}{l}\text { Estar-comedor- } \\
\text { cocina }\end{array}$ & $14 \mathrm{~m}^{2}$ & 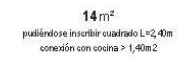 & 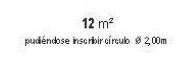 & $17 \mathrm{~m}^{2}$ & $12 \mathrm{~m}^{2}$ & 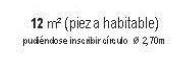 \\
\hline Estar-comedor & $10 \mathrm{~m}^{2}$ & 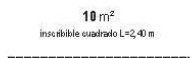 & 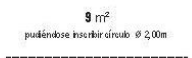 & 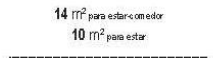 & $10 \mathrm{~m}^{2}$ & 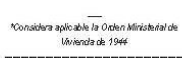 \\
\hline Cocina & $5 \mathrm{~m}^{2}$ & - & 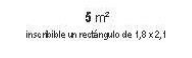 & 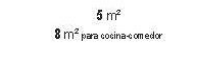 & $5 \mathrm{~m}^{2}$ & 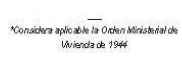 \\
\hline Dormitario doble & $10 \mathrm{~m}^{2} y_{25} \mathrm{~m}^{2}$ & 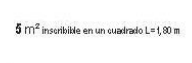 & 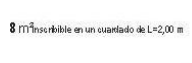 & 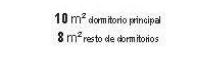 & $8 \mathrm{~m}^{2}$ & 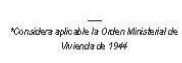 \\
\hline $\begin{array}{l}\text { Dormitorio } \\
\text { simple }\end{array}$ & $6 m^{2} y 15 m^{2}$ & 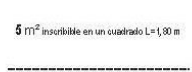 & $6 \mathrm{~m}^{2}$ & $6 \mathrm{~m}^{2}$ & $6 \mathrm{~m}^{2}$ & 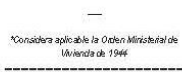 \\
\hline Aseos & $1,5 \mathrm{~m}^{2}$ & - & $1,5 \mathrm{~m}^{2}$ & - & $1,5 \mathrm{~m}^{2}$ & 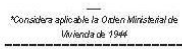 \\
\hline Ancho pasillos & $\begin{array}{c}0,80 \mathrm{~m} \\
1 \mathrm{~m} \text { enarceso }\end{array}$ & - & $0,70 \mathrm{~m}$ y $2 \mathrm{~m}$ de altura & $0,70 \mathrm{~m}$ & $0,70 \mathrm{~m}$ & 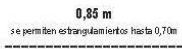 \\
\hline \multirow[t]{2}{*}{ Altura minima } & $\begin{array}{l}2,50 \mathrm{~m} \text { enmedo untano } \\
2,20 \mathrm{~m} \text { en masilo nral }\end{array}$ & - & 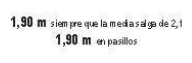 & 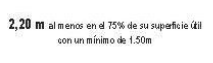 & $2,20 \mathrm{~m}$ & 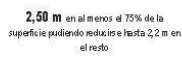 \\
\hline & Iluminación y ventilación & & & & & \\
\hline $\begin{array}{l}\text { Patios interiores } \\
\text { (dimensiones } \\
\text { pemitidas) }\end{array}$ & 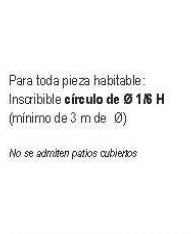 & $\begin{array}{l}\text { Parr estares y domitonos: } \\
\text { en nirulo de } \\
\text { minimu } 4 \mathrm{~m}^{2}\end{array}$ & 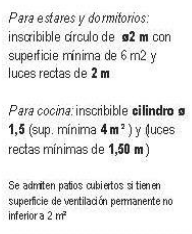 & $\begin{array}{l}\text { Sin referencia a condiciones de } \\
\text { patios }\end{array}$ & 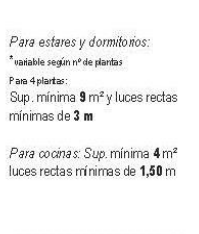 & $\begin{array}{l}\text { Para estares y domitorios: } \\
\text { ancho H/3 } \\
\text { (ninimo } 3 \mathrm{~m} \text { ) } \\
\text { Para cocinas: ancho } \mathrm{H} / 4 \\
\text { (ninimo } 3 \mathrm{~m} \text { ) }\end{array}$ \\
\hline 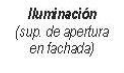 & 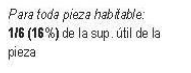 & $\begin{array}{l}\text { Para estares: } 0,80 \mathrm{~m}^{2} \\
\text { Para dommiorios: } 0,40 \mathrm{~m}^{2}\end{array}$ & 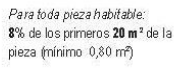 & $\begin{array}{l}\text { Para foda pizzz habitiable: } \\
5 \% \text { dela sup. util de la pieza }\end{array}$ & 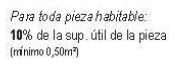 & $\begin{array}{l}\text { Para toda piezz habitable: } \\
12 \% \text { de la sup. util de la pieza }\end{array}$ \\
\hline $\begin{array}{l}\text { Ventilación } \\
\text { sup de apertura }\end{array}$ & $\begin{array}{l}\text { Para foda piezz habut abbie: } \\
1116 \text { (116\%) de la sup. util de la } \\
\text { pieza }\end{array}$ & $\begin{array}{l}\text { Para estares: } 0,80 \mathrm{~m}^{2} \\
\text { Para dormtorios: } 0,40 \mathrm{~m}^{2}\end{array}$ & $\begin{array}{l}\text { Para toda pieza habitable: } \\
13 \text { de la superticie iluminada }\end{array}$ & $\begin{array}{l}\text { Para toda piezza habitabie: } \\
13 \text { de la superticie iluminada }\end{array}$ & $\begin{array}{l}\text { Para fodap pizza habitiable: } \\
\text { 12 de la superficiei liuminada }\end{array}$ & \\
\hline en rachada) & 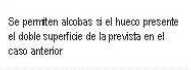 & 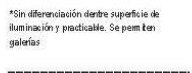 & 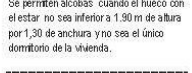 & 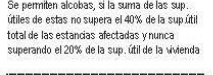 & 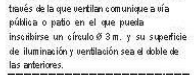 & 8\% de la sup. útil de la pieza \\
\hline
\end{tabular}

Fuente: José María Ezquiaga y Guiomar Martin Domínguez, 2020.

ACE, 15 (4.3) CC BY-ND 3.0 ES | UPC Barcelona, España | Hay que Defender la Ciudad: De la Distopía a la Ciudad 17 Abierta. DOI: http://dx.doi.org/10.5821/ace.15.43.9518 
Tabla 2. Normativa de condiciones mínimas de habitabilidad para vivienda nueva en la legislación española

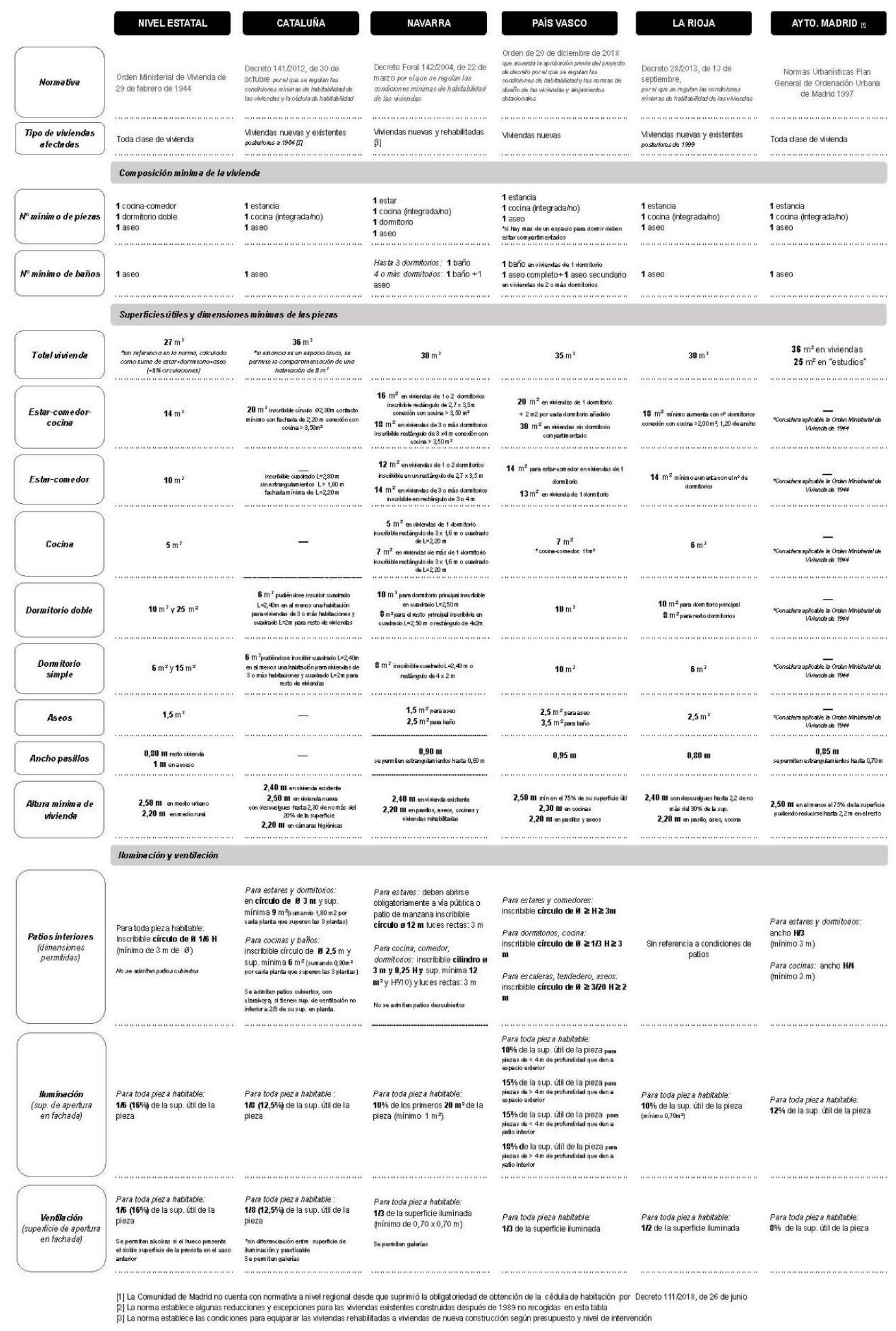

Fuente: José María Ezquiaga y Guiomar Martin Domínguez, 2020.

ACE, 15 (4.3) CC BY-ND 3.0 ES | UPC Barcelona, España | Hay que Defender la Ciudad: De la Distopía a la Ciudad 
Una lectura atenta de las tablas 1 y 2 nos muestra que el ejercicio de la potestad legisladora de las Comunidades Autónomas apenas ha generado progresos significativos respecto a los mínimos habitacionales de la Orden Ministerial de 1944 para las viviendas existentes que vayan a ser reformadas o rehabilitadas. Incluso en algunos parámetros se ha producido un retroceso respecto a requerimientos exigibles. Véase en concreto la reducción del cubicaje de las habitaciones, y alturas libres admisibles en algunas piezas de 2,20 metros o la reducción de las exigencias de ventilación de las habitaciones e incluso de los patinillos de luces, que en determinados casos pueden ser cerrados. Todos estos parámetros son manifiestamente contrarios a la profilaxis de la nueva pandemia de transmisión aérea e incrementan el riesgo del conjunto de los habitantes del inmueble.

Para la vivienda nueva los estándares no son sustancialmente mejores. En concreto en Madrid se permiten estudios de $25 \mathrm{~m}^{2}$ en una sola pieza. Es indudable que en estas condiciones es materialmente imposible mantener la distancia de seguridad en caso de cuarentena entre convivientes, habiéndose de recurrir obligadamente al internamiento hospitalario o a espacios habilitados para el aislamiento temporal. Es muy conveniente una revisión sustancial de estos parámetros desde la óptica de los cambios en los estilos de vida y convivencia en los múltiples formatos familiares, así como la previsión de situaciones singulares de emergencia como la experimentada durante la cuarentena domiciliaria. Será necesario una reflexión en profundidad sustentada empíricamente sobre los cambios en los modos de habitar de los hogares españoles, todavía no suficientemente conocidos.

El reciente decreto de habitabilidad del País Vasco apunta en esa dirección. El incremento de la superficie mínima de algunas de las piezas clave como la cocina para permitir la mejor conciliación de las tareas domésticas. La mejor interconexión entre el interior y el exterior de la vivienda a través de las terrazas o estancias abiertas al aire libre, que no sólo dejan de computarse como superficie útil de la vivienda a efectos de la edificabilidad, sino que pasan a entenderse como partes del programa mínimo de vivienda asignándoles una superficie mínima de $4 \mathrm{~m}^{2}$. Estos elementos deberán añadirse criterios de adaptación flexible de la disposición de las piezas de la vivienda para adaptarse a la evolución de las necesidades de la familia o a la posibilidad de integrar el teletrabajo a partir de formatos de vivienda productiva como se analizará más adelante.

\section{La reinvención del espacio público}

La calle representa en la ciudad tradicional la esencia de la idea de urbanidad. Es el elemento decisivo de la estructura urbana que descansa sobre una adecuada distribución de los espacios públicos en un tejido urbano concebido como un sólido continúo construido. Al mismo tiempo, la calle es un espacio muy complejo susceptible de acoger simultánea o sucesivamente las necesidades de representación, movilidad, relación personal, comercio o el mero paseo ocioso.

A lo largo de los siglos XVIII y XIX la cultura de la calle se incorporó como tal a la disciplina arquitectónica, codificándose y conceptualizándose en práctica del trazado barroco. Werner Oeschslin ha destacado el papel innovador de los textos de Pierre Patte (figura 9) o Francesco Milizia. El primero propiciando el entendimiento de la calle como un problema arquitectónico capaz de ser formulado como tal y el manejo gráfico de la sección viaria como instrumento de proyecto y el segundo incorporando la calle en el orden distributivo del contexto urbano como elemento integrante de la arquitectura pública, junto a las puertas urbanas, puentes, puertos, etc. Pero el manual publicado por Adolph Alphand en 1867, expresivamente titulado -Les Promenades de Paris- es el máximo exponente de una cultura que entiende el espacio público de la ciudad burguesa como objeto de proyecto - merecedor del mismo cuidado que el espacio interior- en cada uno de sus elementos: dimensiones, materiales, plantaciones vegetales y mobiliario urbano.

ACE, 15 (4:3) CC BY-ND 3.0 ES | UPC Barcelona, España | Hay que Defender la Ciudad: De la Distopía a la Ciudad 19 Abierta. DOI: http://dx.doi.org/10.5821/ace.15.43.9518 


\section{ACE Architecture, City and Environment}

Figura 9. Pierre Patte Plan Générale de París 1769. Sección de una calle

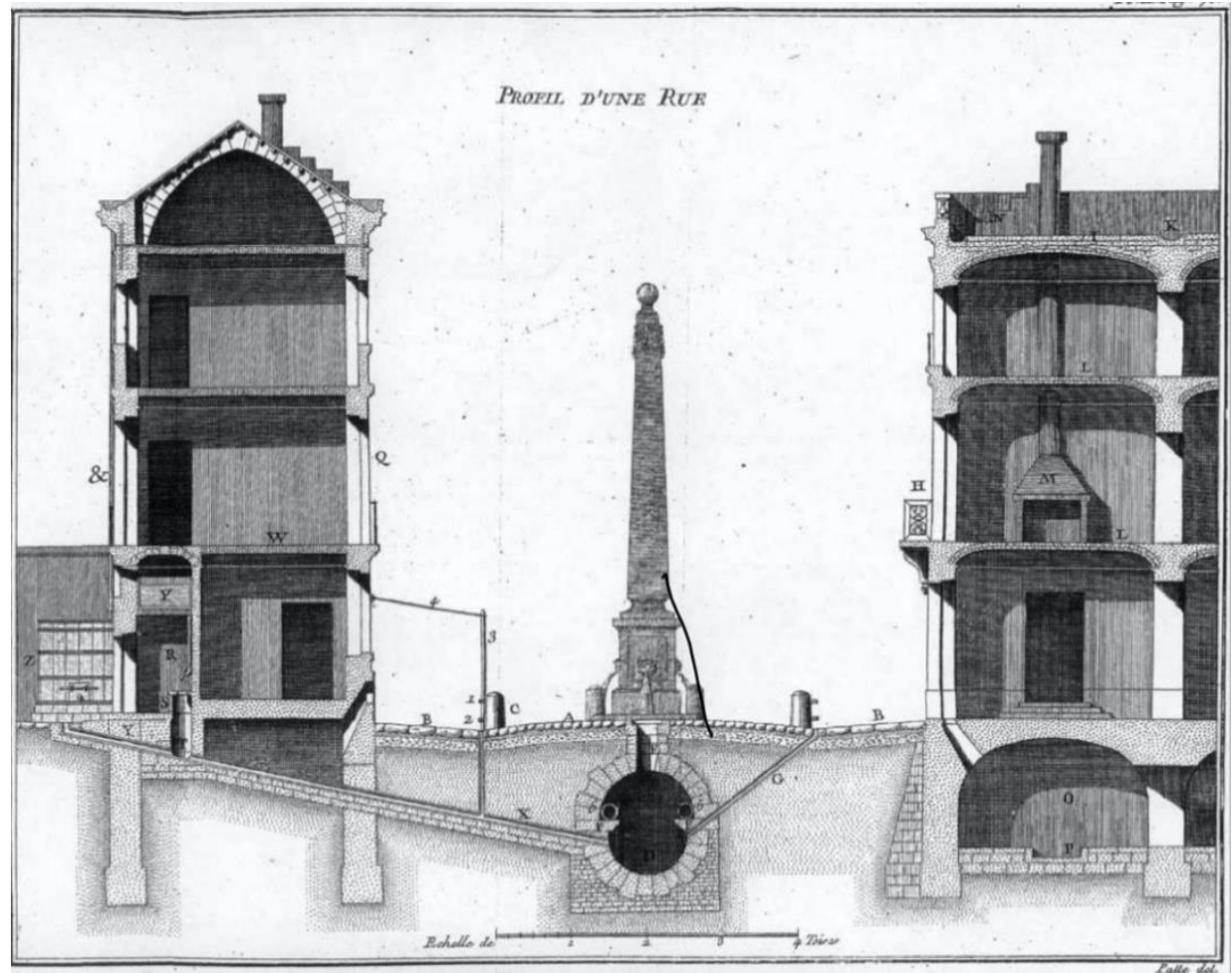

Fuente: Pierre Patte Monumens Érigés en France à la Gloire de Louis XV.

Figura 10. Plano de la New Town de Edimburgo 1834

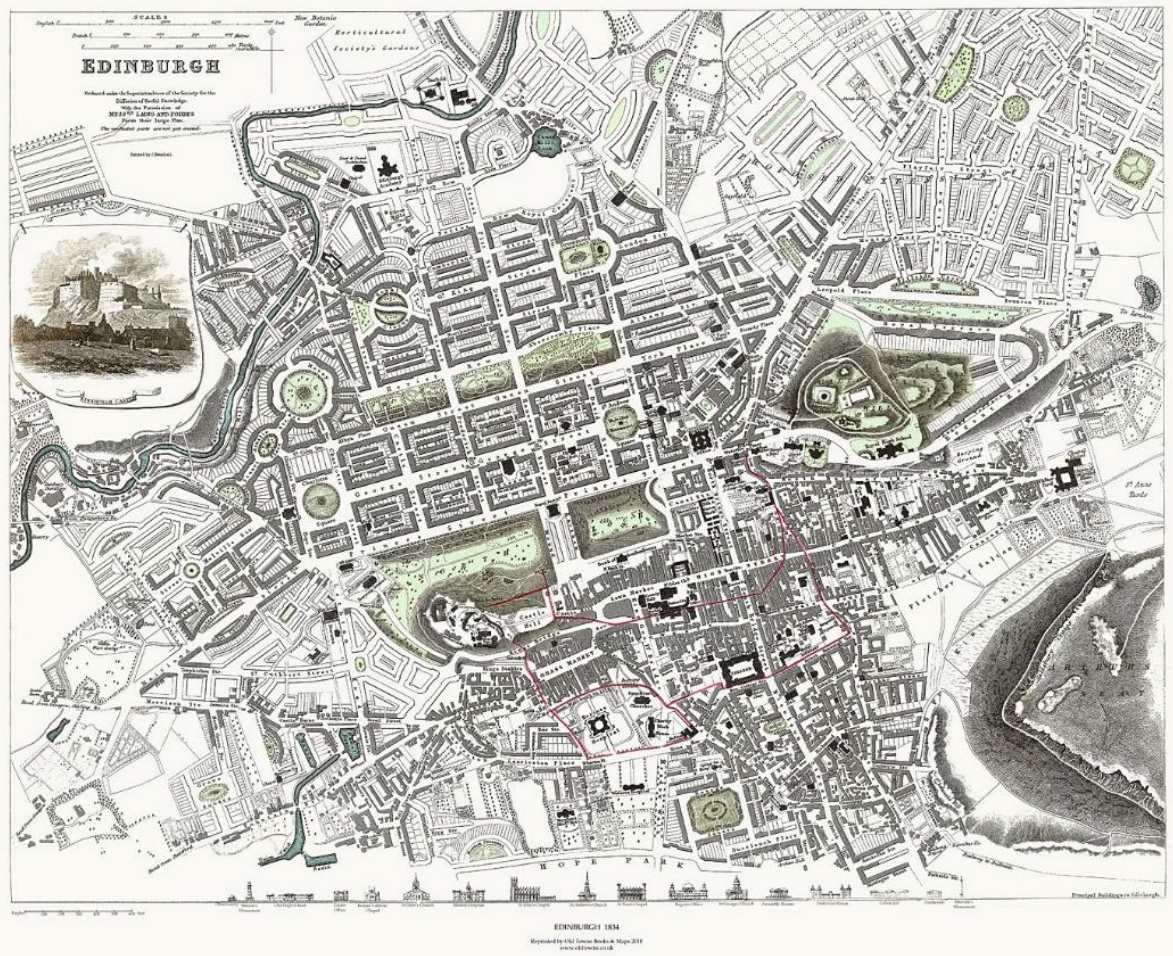

Fuente: Dominio público.

ACE, 15 (4:3) CC BY-ND 3.0 ES | UPC Barcelona, España | Hay que Defender la Ciudad: De la Distopía a la Ciudad

Abierta. DOI: http://dx.doi.org/10.5821/ace.15.43.9518 
Esta reflexión alcanzará una dimensión urbana más tarde con la edición del American Vitrivius de Hegemann y Peets, en 1922. Este libro constituye la síntesis, y al tiempo el canto del cisne, de una aproximación artística a la ciudad que se propone combatir el caos y la anarquía en la arquitectura, enfatizando el ideal de un arte cívico y la posibilidad de una ciudad ilustrada. A principios del siglo XX era ya evidente la violenta solución de continuidad en la cultura cívica de la calle, producida por la emergencia de la metrópolis moderna. La búsqueda ansiosa de un orden se evidencia aquí como síntoma del malestar cultural que produce la ausencia de cualidad del espacio urbano moderno y la imposibilidad de acceder a la comprensión de la condición metropolitana emergente.

A esta realidad contextual corresponde en la reflexión urbanística una etapa de beligerancia dialéctica en contra de la calle tradicional desde presupuestos opuestos a los definidos por el arte cívico (figura 10). Sin duda, la opinión más radical y persuasiva al respecto fue expresada por Le Corbusier en su provocador eslogan: hay que matar la calle corredor (Figura 11). Ahí en esta hostilidad un fundamento racional, pero también un sustrato emocional, un rechazo moral, semejante a la conexión entre insalubridad le inmoralidad característica de los orígenes del pensamiento higienista. "Una calzada; la mayoría de las veces con unas aceras estrechas o anchas. A pico por encima, unas murallas de casas (...) la calle está en el bajo fondo de esta aventura; está en una penumbra eterna. El azul es una esperanza lejana, muy alta. La calle es un canalizo, una zanja profunda, un pasillo estrecho. Se toca a sus dos paredes con los codos del corazón; el corazón se siente siempre oprimido... aunque esto dure desde hace mil años." (Le Corbusier, 1930)

Figura 11. Le Corbusier: Hay que matar la calle corredor

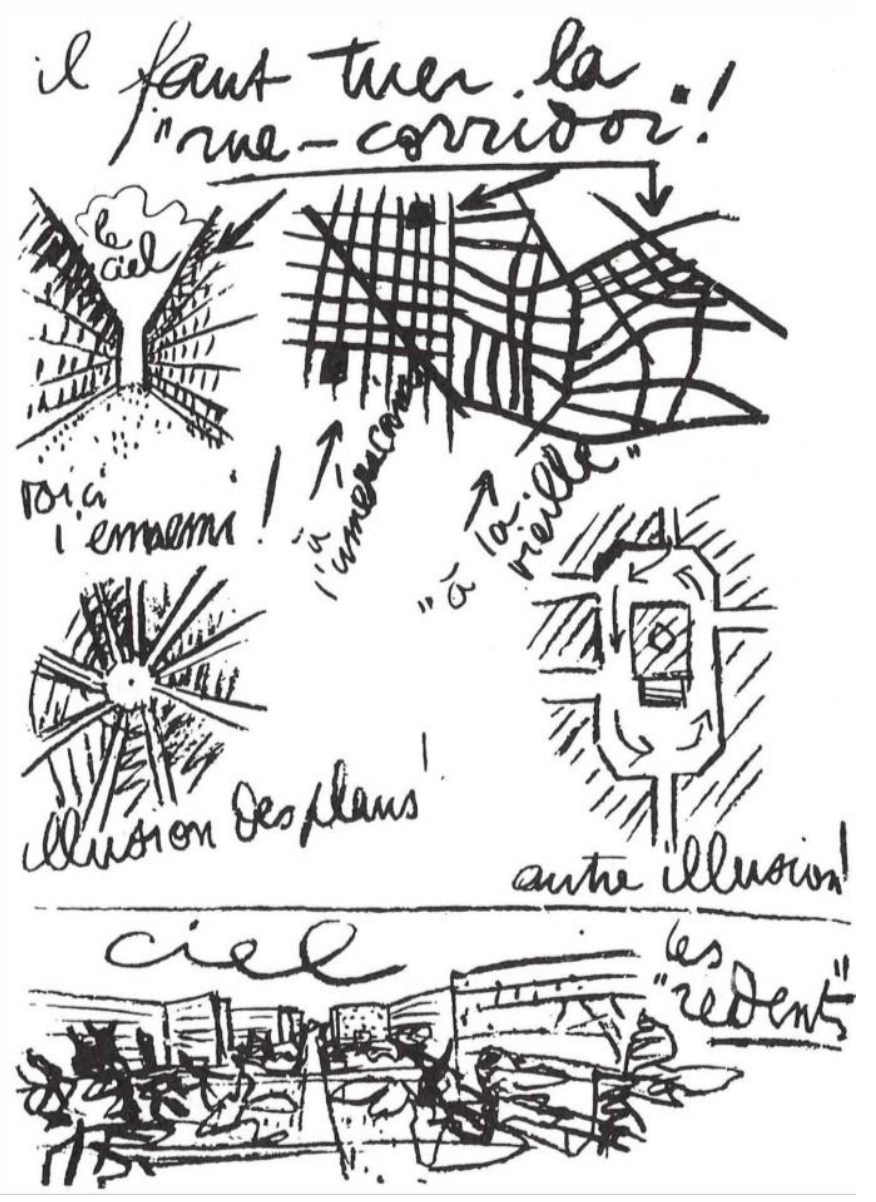

Fuente: Le Corbusier: Précisions, 1930.

ACE, 15 (4:3) CC BY-ND 3.0 ES | UPC Barcelona, España | Hay que Defender la Ciudad: De la Distopía a la Ciudad 


\section{ACE Architecture, City and Environment}

A calle tradicional la Carta de Atenas opondrá el principio de las construcciones que proceden de dentro afuera. Es decir, el entendimiento de la matriz del espacio urbano como vacío continuo sobre el que se disponen los objetos arquitectónicos, potencialmente capaces por sí mismos de establecer una sintaxis coherente. La calle como elemento referencial de las construcciones y la parcela como mediadora de la huella del edificio sobre el terreno se eluden. Hay que buscar las razones de la desintegración de la calle -y de todo espacio organizado-, en el impacto de dos nuevas realidades: un crecimiento urbano que demanda formas más simples y racionales de alojamiento masivo y las exigencias de la generalización del automóvil. En palabras de Rowe y Koetter (1978): Si la configuración de la vivienda evolucionaba ahora desde dentro hacia fuera, a partir de las necesidades lógicas de la unidad residencial individual, ya no podía estar supeditada a presiones exteriores, y si el espacio púbico exterior se había vuelto tan caótico funcionalmente como para carecer de significado efectivo, no podía ejercer ya presiones válidas.

Figura 12. El Cairo

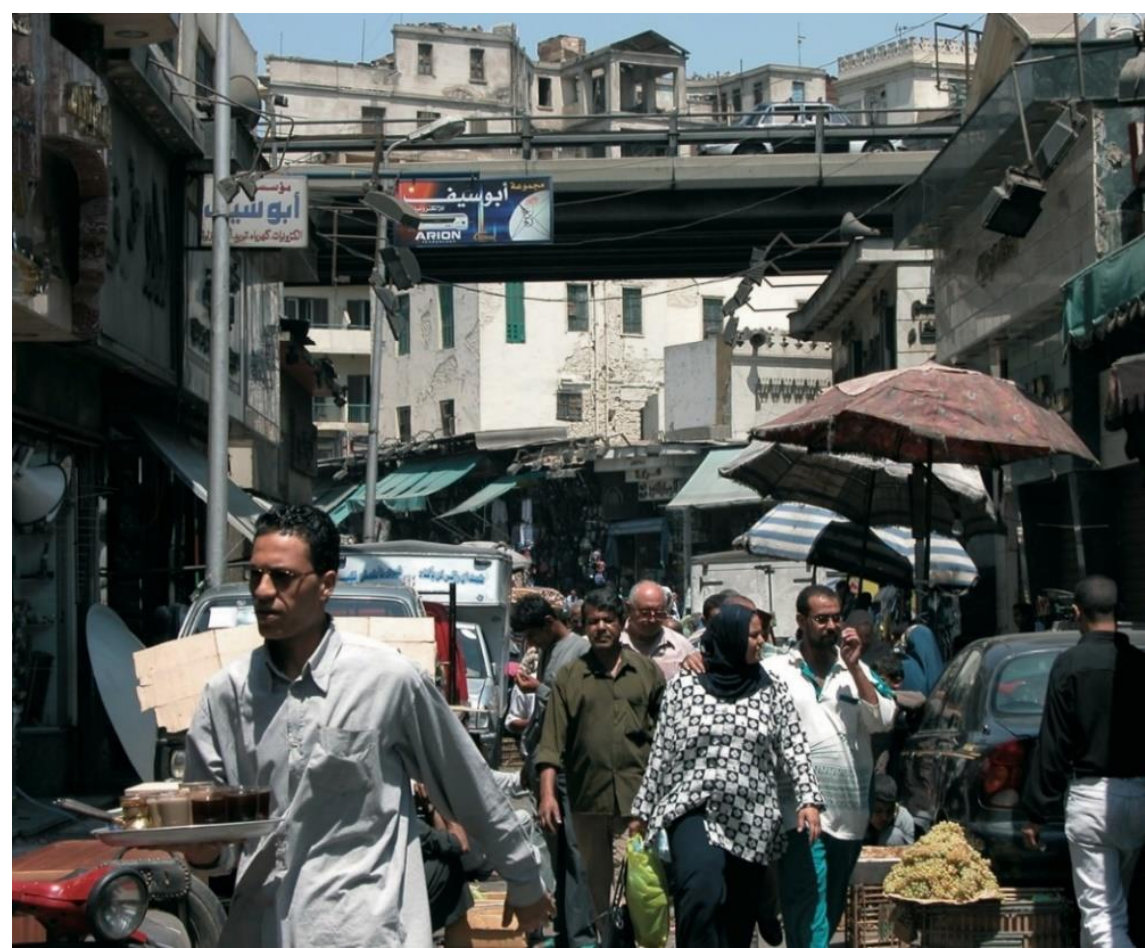

Fuente: Maria Golia.

El problema de la difícil compatibilidad entre las velocidades mecánicas y humanas, planteado por la extensión del automóvil, se resuelve a partir del principio de la especialización de las calles conforme a su destino (calles de vivienda, paseo, tránsito, arterias principales), estableciéndose circuitos autónomos para cada una de las funciones dominantes. El resultado de esta tendencia a la especialización es bien conocido: la circulación se hace dueña y señora de todo el terreno (figura 12). La experiencia del confinamiento ha puesto en crisis este paradigma evidenciando las ventajas de los lugares donde la gente vive suficientemente cerca para acceder peatonalmente a los servicios que necesita y los beneficios colaterales de la reducción de la movilidad: la visible mejora de la calidad del aire y la reducción del ruido. Pero ha hecho, asimismo, patente el conflicto entre un espacio público diseñado al servicio del automóvil y la movilidad peatonal y las demandas de las actividades económicas a pie de calle, en particular la hostelería.

Durante el breve período de cuarentena domiciliaria el conjunto de la ciudadanía ha podido percibir desde la perspectiva peatonal la desequilibrada distribución del espacio público en favor del 
automóvil privado. En grandes ciudades como Madrid el área destinada a circulación y aparcamientos supone más del 70\% del espacio disponible. De este espacio asfaltado cerca del 30\% viene ocupado por el aparcamiento. Esta distribución no se corresponde al peso de la distribución modal de los viajes. En entornos de media y alta densidad los desplazamientos peatonales satisfacen más de la mitad de los viajes diarios.

Algunas administraciones locales, como la ciudad de Nueva York, han modificado sus estándares de aparcamiento residencial. El Manhattan Core Text Amendment, aprobado en 2013, elimina en una amplia zona del centro de la ciudad el estándar mínimo de aparcamiento, y limita el número máximo posible de plazas, como resultado de un estudio exhaustivo del parque existente y su relación con los usos actuales y permitidos por el planeamiento.

Todo ello pone de manifiesto la necesidad un nuevo contrato cívico en favor de la prioridad peatonal y la sensibilidad hacia las necesidades de los diversos segmentos de la población urbana, empezando por los más vulnerables: niños y mayores. No sólo se trata de ampliar las aceras temporalmente para hacer posible el mantenimiento de la distancia de seguridad, cuanto de redefinir el papel del espacio público desde nuevos criterios: Prioridad al confort y seguridad peatonal y fomento de la más amplia variedad posible de actividades económicas y equipamientos para asegurar la vitalidad de las calles. Estas acciones son perfectamente compatibles con estrategias ambiciosas de renaturalización de la ciudad sustentadas en una infraestructura verde multiescalar, que atienda desde la más diminuta esquina de barrio hasta los grandes espacios naturales y rurales de escala regional.

Se hace necesaria la reinvención del espacio público como gran argumento de la transformación urbana, desde la perspectiva de la limitación y racionalización de la preeminencia del automóvil privado y la recuperación de la calle como espacio ciudadano para la movilidad peatonal y ciclista, la actividad económica, el descanso y el encuentro (Crawford, 2011). Trabajar la interrelación entre calle y edificio abre también la posibilidad de repensar las funciones, densidad y configuración volumétrica de los espacios construidos.

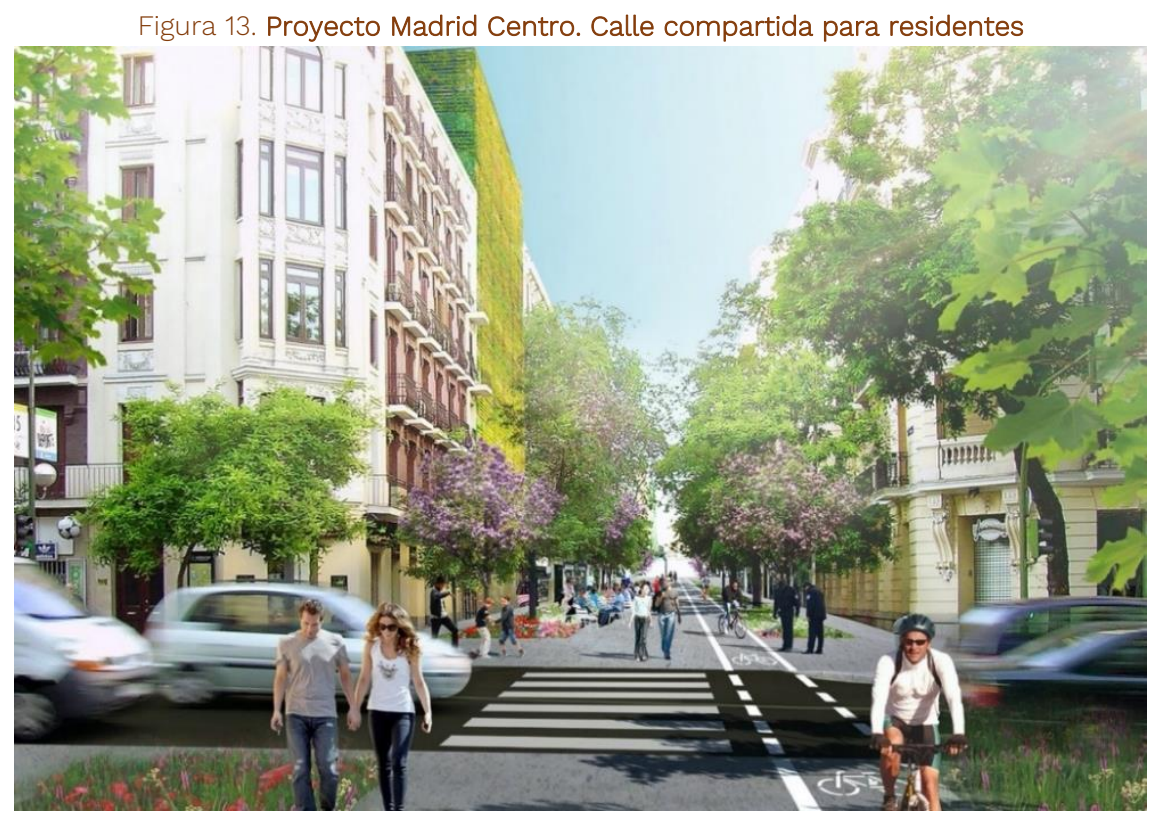

Fuente: José María Ezquiaga, Juan Herreros y Salvador Pérez Arroyo. Proyecto Madrid Centro 2011.

Dentro de ciertos límites estos propósitos son alcanzables en el marco del planeamiento urbano tal como lo concebimos. Es posible contemplar en los Planes municipales una más equilibrada

ACE, 15 (4.3) CC BY-ND 3.0 ES | UPC Barcelona, España | Hay que Defender la Ciudad: De la Distopía a la Ciudad 23

Abierta. DOI: http://dx.doi.org/10.5821/ace.15.43.9518 
distribución del espacio público y equipamientos que no sólo atienda a la satisfacción de los estándares legales cuantitativos cuanto a una adecuada distribución espacial en función de las distintas escalas geográficas y de las necesidades humanas. Lamentablemente es difícil encontrar en la legislación urbanística criterios que promuevan proactivamente la calidad de la ciudad cercana en las áreas consolidadas y vínculos entre la densidad humana real y la localización espacial de los equipamientos y zonas verdes en las áreas de nuevo desarrollo.

\section{Defender el equilibrio entre densidad urbana y habitabilidad. La ciudad "mediterránea"}

La densidad está asociada asocia a la noción de intensidad. Sabemos desde Simmel que este es uno de los rasgos más esenciales de la ciudad moderna y la base sobre la que se sustenta su extraordinaria complejidad de relaciones sociales. El crecimiento de la población urbana se ha acelerado en las últimas décadas, pero la ocupación de suelo resultante su expansión física ha crecido varias veces más que la población. Esta divergencia está asociada a la especulación del suelo, la carencia de planeamiento y cambios en los estilos de vida de los habitantes. Es revelador que el fenómeno no se limita a los países desarrollados, donde los crecimientos suburbanos de baja densidad apoyados en las infraestructuras rodadas en la universalización de la utilización de automóvil han generado desde los años 50 una dramática disminución de la densidad urbana, sino que también afecta a los países menos desarrollados en los que la ratio de crecimiento de la huella urbana en el periodo 1990-2015 duplica la ratio de incremento de la población urbana. (Angel et al., 2012 y 2015; Brenner, 2014)

Como consecuencia de la expansión incontrolada de la huella urbana las densidades urbanas están disminuyendo significativamente tanto en los países más desarrollados como los menos desarrollados. En estos últimos, la ratio de personas por hectárea se ha reducido a la mitad desde 1990 pero es todavía significativamente más elevada que en los países desarrollados, en los que la media no alcanza los 30 hab./ha. Las consecuencias para la sostenibilidad urbana y medioambiental son dramáticas, pensemos el incremento en el consumo de suelo asociado a un 1\% de reducción anual en la densidad urbana doblaría la huella urbana a escala planetaria en el año 2050. Como consecuencia de la presión sostenida de la urbanización, se está produciendo una pérdida de hábitat natural y rural sin precedentes históricos y tienden a multiplicarse los espacios residuales en expectativa de desarrollo situados en los márgenes discontinuos de las áreas urbanizadas.

Hay un amplio consenso entender que nos encontramos ante un nuevo territorio que cambia las escalas de comprensión de los hechos urbanos y multiplica las dimensiones de su complejidad requiriendo nuevas herramientas de planificación y gestión urbanística, como será analizado más adelante. La universalización de la ciudad dispersa ha situado, de nuevo, en el centro del pensamiento urbanístico la opción por la ciudad densa y compacta como dimensiones estratégicas de la sostenibilidad y la intensidad de la vida urbana.

De pronto, la clave del éxito de las ciudades - la proximidad de muchas personas- deviene en vulnerabilidad frente a la pandemia y la densidad aparece ahora como una amenaza. (Bassett, 2020; Rosenthal, 2020). En un polémico artículo, Joel Kotkin (2020) defiende que el controvertido modelo disperso de Los Ángeles se ha mostrado como el mejor activo para controlar la pandemia. Para avalar esta idea utiliza el concepto de densidad de exposición vinculándolo a la dependencia de los núcleos urbanos más densos respecto del transporte colectivo. El tema es particularmente candente después de que simulaciones epidemiológicas hayan concluido que el metro de Nueva York (Figura 14) fue durante su funcionamiento el principal vector de propagación de la epidemia (Harris, 2020). El propio gobernador Andrew Cuomo ha llegado a calificar el nivel de densidad de NYC como destructivo (Badger, 2020).

ACE, 15 (4:3) CC BY-ND 3.0 ES | UPC Barcelona, España | Hay que Defender la Ciudad: De la Distopía a la Ciudad 24 Abierta. DOI: http://dx.doi.org/10.5821/ace.15.43.9518 


\section{ACE Architecture, City and Environment}

E-ISSN 1886-480

Figura 14. New York Avenida de las Américas

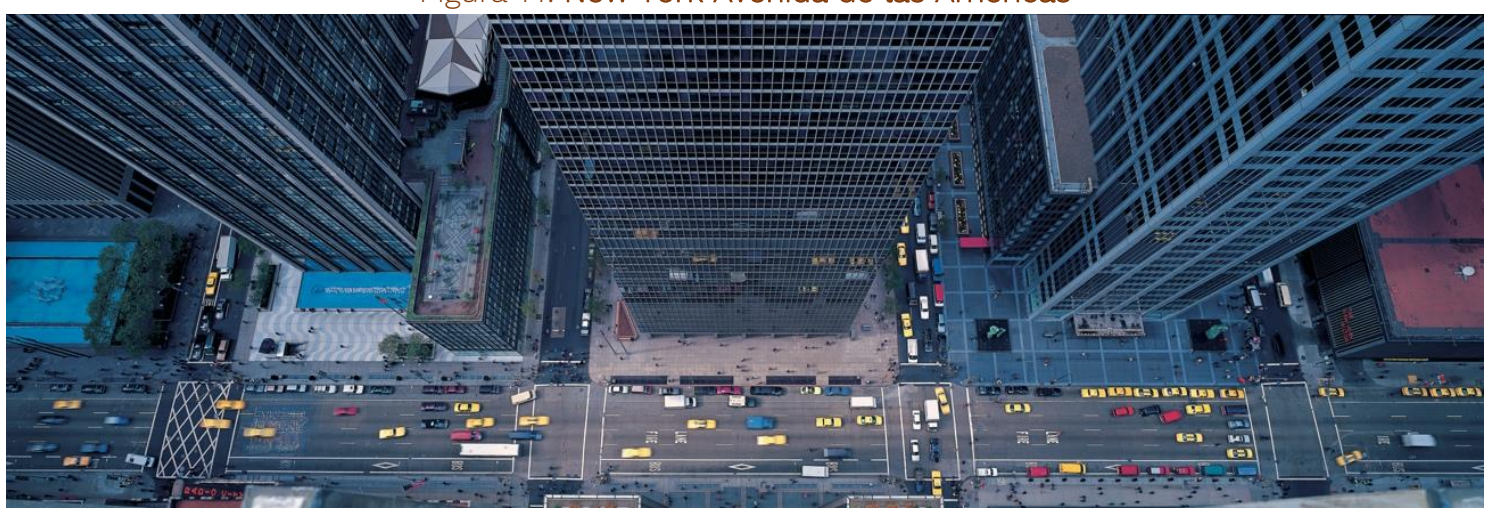

Fuente: Richard Berenholtz.

Sin embargo, una visión más amplia cuestiona la relación causal entre la densidad urbana y el impacto del coronavirus. Recordemos qué algunos de los núcleos urbanos más densos del mundo: Hong Kong (Figura 15), Singapur, Seúl, o Tokio han logrado contener la epidemia utilizando estrategias alternativas al confinamiento (Kling, 2020). Al mismo tiempo, asentamientos de menor tamaño y densidad han sufrido serios impactos. Hay otras variables vinculadas al conocimiento, a la organización social, a la calidad de las infraestructuras vitales o al modo de gestión de la epidemia que están incidiendo significativamente en el impacto.

Figura 15. Hong Kong

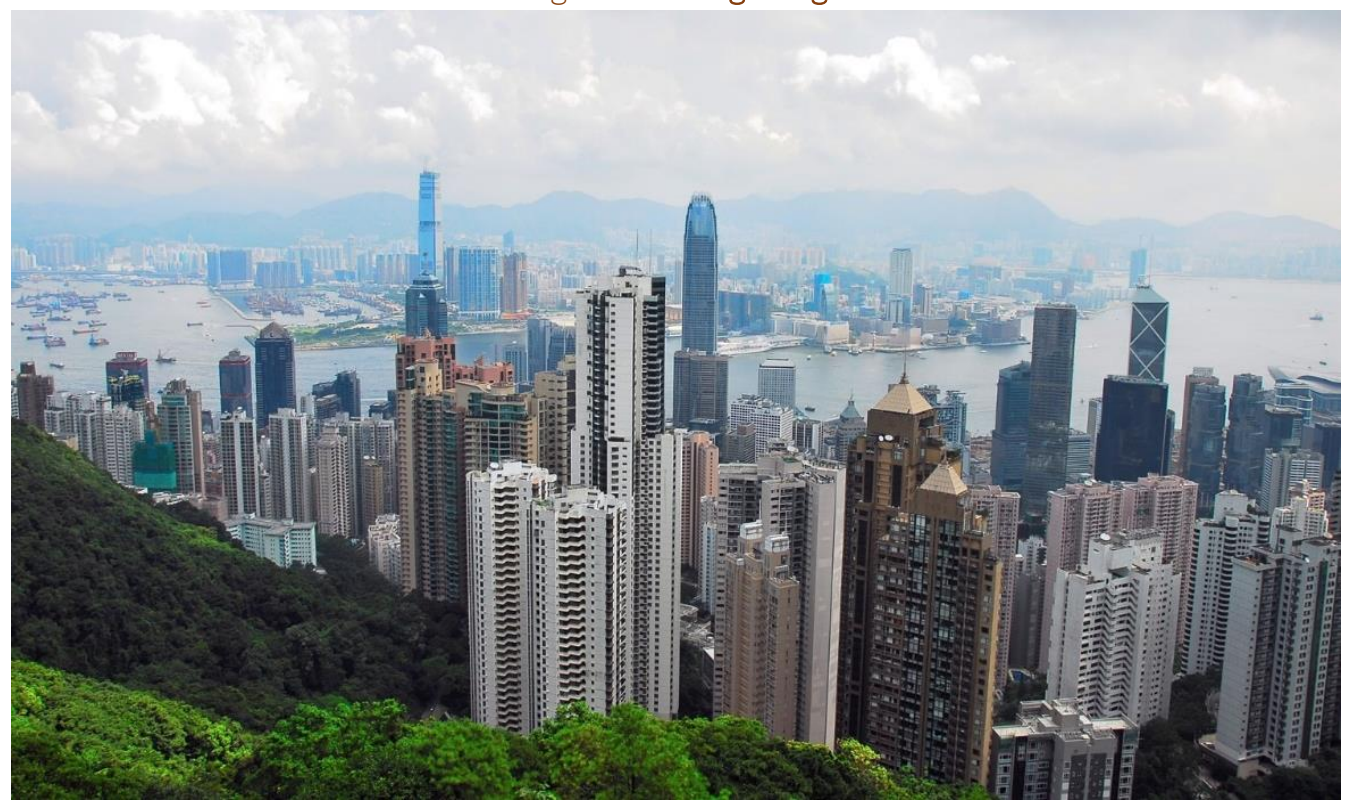

Fuente: José María Ezquiaga.

Como ha recordado Richard Florida (2020b), es necesario considerar el tipo de densidad. La diferencia evidente entre los distritos densos de mayor renta donde las personas pueden protegerse en sus hogares, tele-trabajar, mantener una distancia social en el espacio público; de los barrios de rentas más bajas en los que la densidad se expresa cómo hacinamiento residencial, déficit espacio público, escasez de servicios y congestión los sistemas de transporte. Además de la densidad hay otros factores que merecen una atención prioritaria para rastrear la propagación del virus: la edad de la población y las condiciones de salud preexistentes tales como tabaquismo, obesidad y diabetes,

Abierta. DOI: http://dx.doi.org/10.5821/ace.15.43.9518 
enfermedades cardiovasculares..., El desigual impacto del virus en función de las condiciones socioeconómicas y finalmente las diferencias entre aquellos trabajadores de primera línea como la sanidad, comercio y mensajería, particularmente vulnerables, y aquellos que tienen la posibilidad de desarrollar su trabajo a distancia. (Florida, 2020a)

A pesar de todo, hay razones de largo aliento que aconsejan seguir defendiendo el modelo de ciudad compacta con densidades razonables. La primera constata el papel de las ciudades como motores el desarrollo social económico. Lo expresaba muy afinadamente un reciente editorial del New York Times (2020) en defensa de la ciudad: "la densidad y diversidad de la vida urbana estimula la acumulación de conocimiento, el intercambio de ideas y la creación de nuevos productos". En suma, la innovación y la creación.

Paradójicamente, como ha señalado Richard Sennett, las medidas de distanciamiento físico durante la emergencia sanitaria han fortalecido otra dimensión de la aglomeración humana: el sentido de comunidad. El confinamiento obligado ha favorecido una mayor conciencia del valor de los vínculos entre personas y grupos diversos. Esto hace más atractiva una segunda ventaja de la densidad: la posibilidad de una cultura de barrio, la ciudad cercana, en la dimensión social que defendiera Jane Jacobs (1961).

Desde el punto de vista ambiental los modelos compactos de ocupación del territorio contribuyen de manera decisiva a la consecución de los estándares básicos de la sostenibilidad urbana. La densidad del hábitat urbano es clave para la reducción del consumo energético, emisiones de gases de efecto invernadero, huella urbana y pérdida de suelo agrícola. Hace también posible una movilidad limpia prioritariamente peatonal en las cortas distancias y un transporte público eficiente para la movilidad obligada a escala metropolitana. Por el contrario, los modelos de asentamientos policéntricos conectados por autopista no sólo suponen una multiplicación del consumo de suelo y del gasto energético, sino que reiteradamente convergen en congestiones Insoportables en los nodos urbanos qué obligan a multiplicar las inversiones en infraestructura para mantener la capacidad del sistema.

Los desarrollos urbanos densidad razonable favorecen la variedad de tipologías edificatorias y, consecuentemente, la interacción y diversidad social, facilitando la implementación de estrategias de revitalización centros urbanos y de barrio. Asimismo, la densidad facilita la concentración de los recursos e infraestructuras sociales y el acceso a los mismos, por ejemplo, hospitales y centros de salud. Esta condición es una ventaja ante los riesgos y catástrofes naturales y tecnológicos. La redundancia y multiplicidad escalar de las redes de infraestructuras urbanas, sanitarias y de protección civil permiten una respuesta resiliente del conjunto en caso de quiebra de alguno de los elementos del sistema, como ocurrió en el caso del 11S o del Huracán Sandy en NYC (Shenker, 2020).

La recientemente aprobada Agenda Urbana Española (2019) incluye entre sus objetivos estratégicos: evitar la dispersión urbana y revitalizar la ciudad existente. Esto se expresa en la búsqueda de un modelo urbano sustentado en la compacidad en su morfología, la complejidad entendida como mixtura de usos y biodiversidad es urbanización, la eficiencia metabólica en su funcionamiento y la cohesión social. Aunque la agenda no llega a formular expresiones cuantitativas para evaluar los conceptos de densidad y compacidad define su alcance de una manera más precisa que la Nueva Agenda Urbana de Naciones Unidas: "La planificación u ordenación del suelo debe perseguir estructuras urbanas compactas y polifuncionales, que prioricen los procesos de reciclaje de los tejidos urbanos existentes, la recuperación de suelos en desuso ubicados en el interior de los ámbitos urbanos y la redensificación de los suelos urbanizables dispersos." (Agenda Urbana Española, 2018, pág. 94-98)

ACE, 15 (4:3) CC BY-ND 3.0 ES | UPC Barcelona, España | Hay que Defender la Ciudad: De la Distopía a la Ciudad

Abierta. DOI: http://dx.doi.org/10.5821/ace.15.43.9518 
La dificultad a la hora de traducir en herramientas operativas los conceptos de densidad, intensidad y compacidad radica en su imprecisión técnica y, en consecuencia, jurídicamente indeterminada. Mientras que la densidad constituye habitualmente una referencia objetiva, expresada en términos cuantitativos de la capacidad de habitación en un ámbito superficial determinado, la intensidad tiende a expresar la medida de la complejidad y riqueza de acontecimientos de un entorno urbano determinado y la compacidad constituye un parámetro geométrico asociado a la continuidad espacial y concentración del tejido urbano.

La medida de la densidad edificatoria o residencial ha tenido históricamente en nuestro país una proyección muy limitada, circunscrita casi en exclusiva a la fijación de la edificabilidad, hoy comúnmente expresada en forma de índice de superficie construida por unidad de superficie de suelo y la limitación del número de viviendas sobre unidad de superficie. La legislación estatal estableció en 1976 un límite convencional para la densidad máxima de viviendas: la referencia canónica de 75 viv/Ha; que durante varias décadas continuó con referente para la mayoría de las nuevas legislaciones urbanísticas. En aquel momento las grandes densidades estaban asociadas en la memoria colectiva a la especulación del suelo y la carencia de las infraestructuras básicas y servicios que caracterizaron la expansión urbana en el periodo de despegue económico acelerado tras el Plan de Estabilización de 1959.

Durante todo este periodo el proceso de formación del urbanismo moderno en España este se desenvuelve en la contradicción entre garantizar un mínimo sustantivo de calidad de vida en el medio urbano y facilitar la urbanización como motor del desarrollo económico. La legislación iniciada en 1956 formuló como objetivo estratégico asegurar la financiación de la obra urbanizadora y garantizar desde el inicio del proceso la reserva de los suelos necesarios para acoger las redes de equipamientos y espacios libres públicos. Objetivos que nunca llegaron a alcanzarse satisfactoriamente desde las legislaciones de Ensanche y Reforma Interior del siglo XIX.

Tabla 3. Estándar de densidades y edificabilidades máximas permitidas en la legislación urbanística

\begin{tabular}{|c|c|c|c|}
\hline \multicolumn{2}{|r|}{ Referencia Normativa } & Densidad residencial máx & Edificabilidad residencial máx \\
\hline Andalucía & $\begin{array}{l}\text { Art 17. Ley 7/2002 de Ordenación } \\
\text { Urbanistica de Andalucia }\end{array}$ & $<90$ viv/ha & $1 \mathrm{~m} 2 \mathrm{c} / 1 \mathrm{~m} 2 \mathrm{~s}$ \\
\hline Castilla La Mancha & Art 31. TRLOTAU & $10.000 \mathrm{~m} 2$ uso residencial/h1 & $1 \mathrm{~m} 2 \mathrm{c} / 1 \mathrm{~m} 2 \mathrm{~s}$ \\
\hline Madrid & Art 6. LSCM 9/2001 & $<100$ viv/ha & - \\
\hline País Vasco & $\begin{array}{l}\text { Art 26. Ley 2/2006 de suelo y } \\
\text { urbanismodel Pais Vasco }\end{array}$ & $<100$ viv/ha & $2,3 \mathrm{~m} 2 \mathrm{c} / \mathrm{m} 2 \mathrm{~s}$ \\
\hline Valencia & $\begin{array}{l}\text { Art } 36 \text { LOTUP } 5 / 2014 \text { de la } \\
\text { Comunidad Valenciana }\end{array}$ & $<100 \mathrm{viv} / \mathrm{ha}$ & $1 \mathrm{~m} 2 \mathrm{c} / 1 \mathrm{~m} 2 \mathrm{~s}$ \\
\hline Nivel Estatal & $\begin{array}{l}\text { Art } 60 \text { ter. Ley } 19 / 1975 \text { de Suelo y } \\
\text { Ordenación Urbana (Estatal) }\end{array}$ & $<75$ viv/ha & - \\
\hline
\end{tabular}

Fuente: Elaboración propia. José María Ezquiaga e Irene Lorite, 2020

La fijación de un límite máximo a la densidad residencial (y no un límite mínimo o una horquilla, como muchas legislaciones urbanísticas actuales contemplan) pretendía impedir que la tendencia a minimizar los costes de urbanización por vivienda produjese densidades residenciales tan elevadas rompieran el equilibrio entre espacio habitable, servicios y dotaciones públicos, generando la saturación de las infraestructuras, congestión y perdida de la calidad ambiental. Asimismo, se orientaba a evitar una reducción del tamaño de las viviendas por debajo de unos criterios mínimos de habitabilidad o de capacidad de acoger una diversidad de necesidades de alojamiento. 
La condición ciertamente arbitraria del parámetro y su insensibilidad a los requerimientos de contextos urbanos y rurales muy diversos no resta valor al hecho de hizo visible la existencia de límites en la capacidad el territorio, abriendo camino al concepto más complejo de capacidad de carga. De la misma manera, los "Módulos mínimos de reserva para dotaciones en suelo residencial", del Anexo al art 10 del RP de 1976 al fijar una correlación entre las dimensiones de las unidades de vivienda y las necesidades de reservas de suelo para equipamientos y zonas verdes, asignó al planeamiento la responsabilidad de conseguir un equilibrio armónico entre la escala de actuación, la densidad residencial y los requerimientos dotacionales de la población, contribuyendo a consolidar una cultura profesional hoy significativamente diluida en la más reciente legislación urbanística. Pero como indicaban García de Enterría y Parejo el concepto de vivienda en el que se sustenta este equilibrio es jurídicamente impreciso, habiendo sido preferible que la proporción estuviera referida a habitantes (1981).

Tabla 4. Estándares dotacionales en Sistemas Generales y Sistemas Locales en la legislación urbanística española

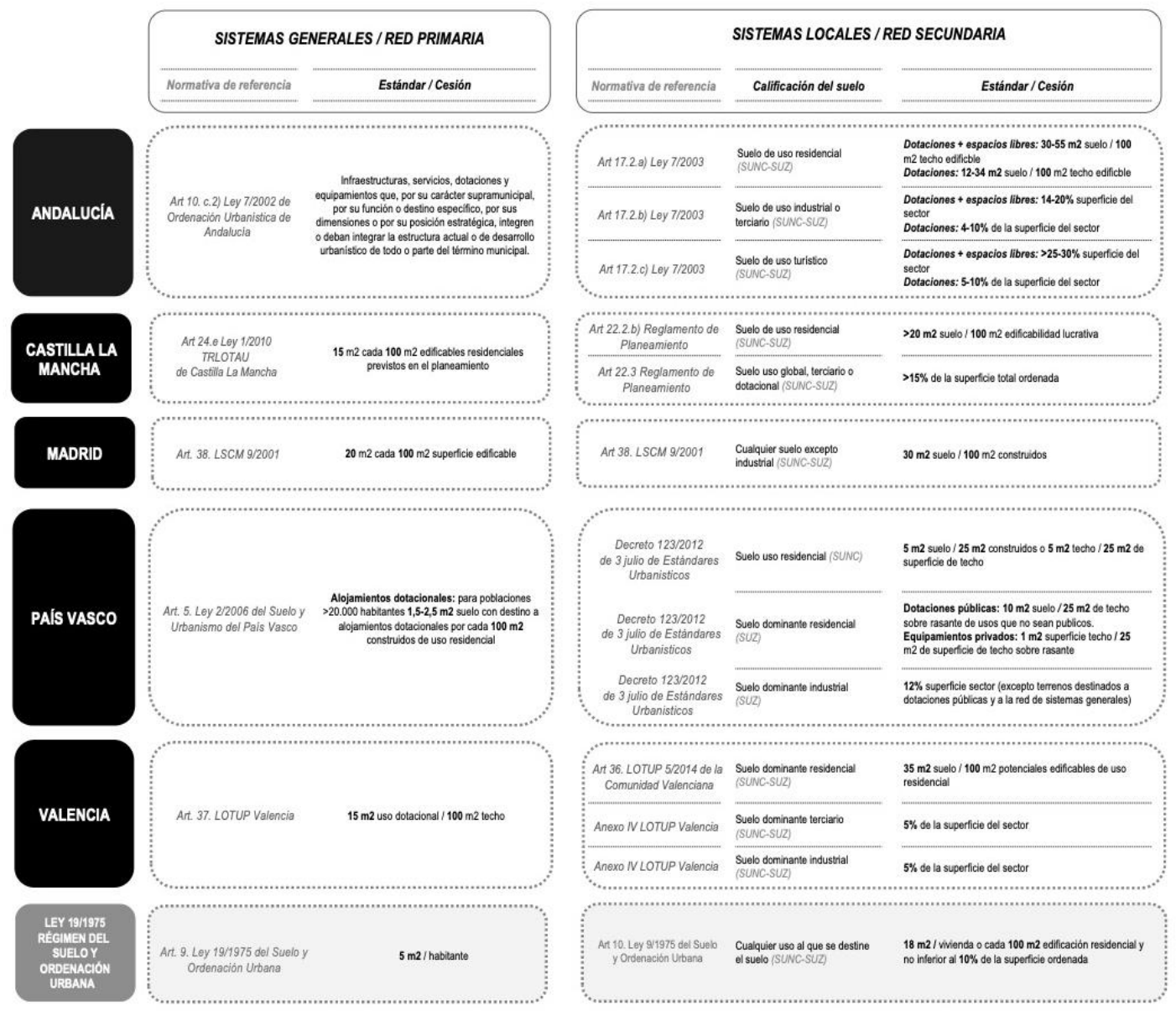

Fuente: Elaboración propia. José María Ezquiaga e Irene Lorite, 2020.

Una primera reflexión importante es que los parámetros de densidad y edificabilidad condicionan las posibilidades de materialización de la morfología urbana y la elección de las tipologías edificatorias, pero no pueden acotar por completo el modelo de ciudad deseado. Ahora bien, la experiencia muestra, en sentido contrario, que una equivocada selección de estos mismos parámetros puede hacer imposible alcanzar criterios de sostenibilidad y malograr cualquier reivindicación a posteriori de la calidad urbana. La reciente tendencia a sustituir parámetros de densidad por máximos de 
edificabilidad ignora uno de los fundamentos básicos del planeamiento moderno: la consecución de un equilibrio racional entre las necesidades de la población en un entorno geográfico determinado y las infraestructuras y servicios cuya provisión debe garantizar la ordenación urbana. De la misma manera la deseable mezcla de usos en los tejidos urbanos debe atender a escenarios flexibles de ajuste entre población e Infraestructuras y servicios.

Tabla 5. Estándares de Zonas Verdes en Sistemas Generales y Sistemas Locales en la legislación urbanística española

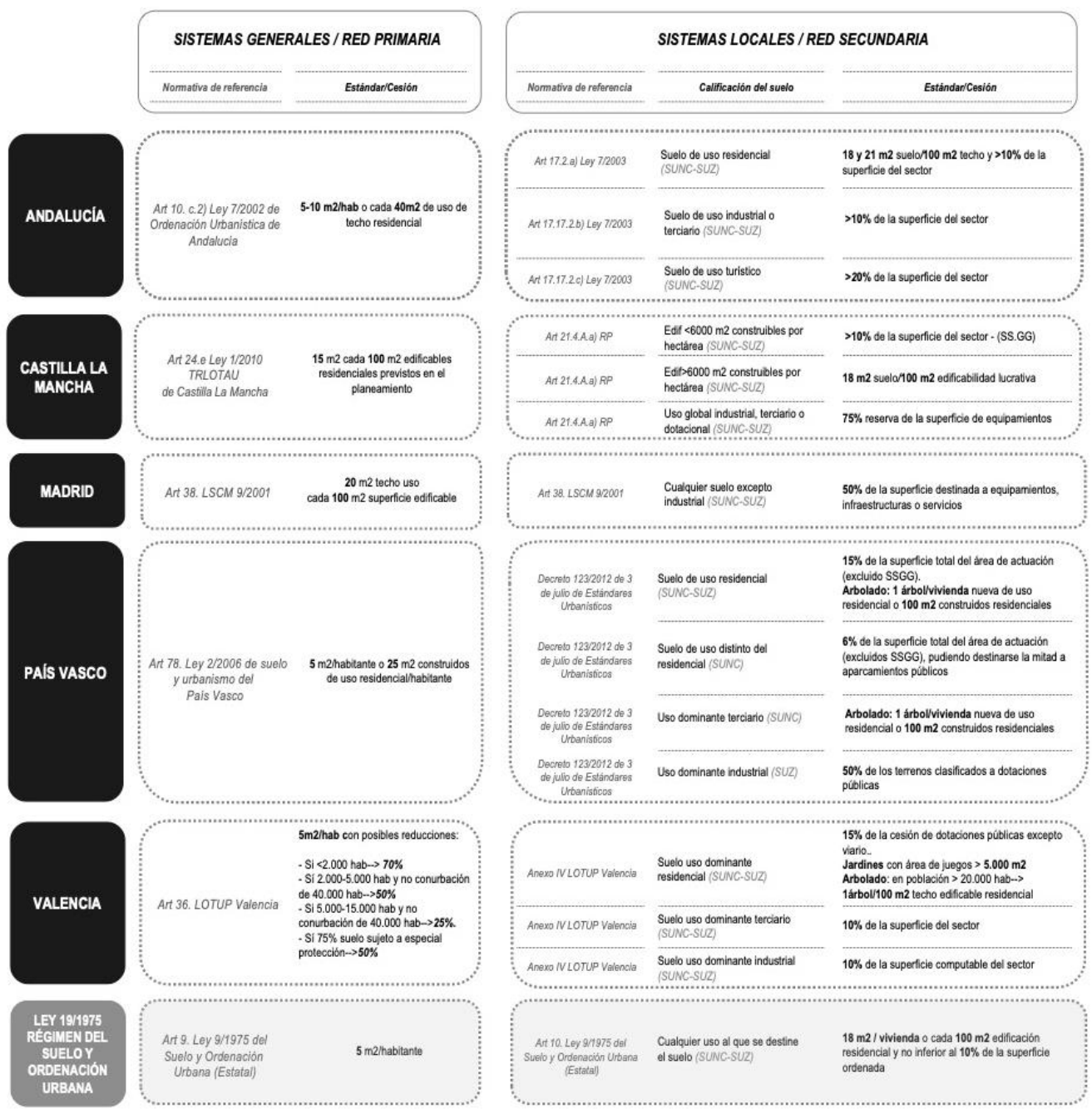

Fuente: Elaboración propia. José María Ezquiaga e Irene Lorite, 2020.

En consecuencia, la medida de la densidad tiene un alcance insuficiente en términos de modelo de ciudad si no se asocia a un ámbito bien definido espacialmente, a la elección de determinadas morfologías urbanas, tipologías edificatorias y mixtura de usos del suelo. Pero la operatividad del parámetro se incrementa conforme aumentemos la escala de referencia, alcanzando su máximo interés como instrumento prescriptivo de los modelos urbanos a escala de barrio, ciudad o región.

Finalmente, la utilización del parámetro más básico de expresión de la densidad: número de viviendas por unidad de superficie, puede completarse con la utilización de otras medidas que ayuden a refinar los análisis y proyectos. El uso del parámetro del número de habitaciones habitables por hectárea tiene poca tradición en nuestro país, aunque ha sido un parámetro profusamente utilizado en el

ACE, 15 (43) CC BY-ND 3.0 ES | UPC Barcelona, España | Hay que Defender la Ciudad: De la Distopía a la Ciudad 29 Abierta. DOI: http://dx.doi.org/10.5821/ace.15.43.9518 
planeamiento británico tradicional (rooms/acre) ya que facilita la estimación del número de niños y el ajuste de la oferta de dotaciones al segmento de población con demandas más sensibles. Una versión de este parámetro referida a personas o número de dormitorios por unidad de superficie puede resultar muy operativo para reflejar la intensidad de uso en determinadas circunstancias, por ejemplo, en desarrollos turísticos, complementando el estándar de número de viviendas por Ha.

Tabla 6. Regulación de los parámetros de densidad en Europa

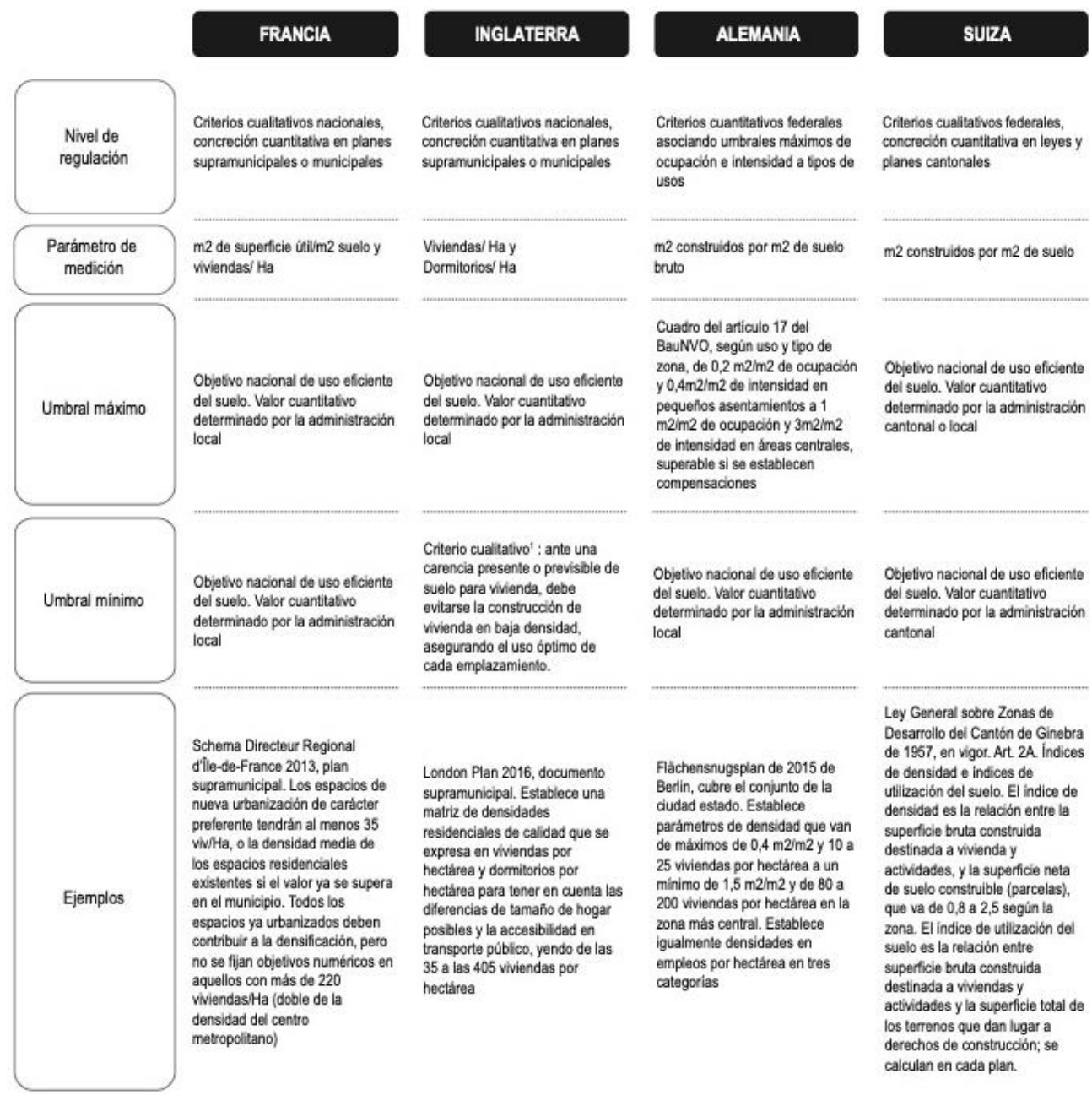

1. El limite minimo de 30 viviHa establecido por la Planning Policy Guidance 3 ha desaparecido con la entrada en vigor del National Planning Policy Framework

Fuente: Elaboración Javier Barros y José María Ezquiaga. 2020.

El Plan de Londres de 2016 -documento supramunicipal-, en línea con la tradición histórica del planeamiento de esta ciudad desde el Plan de Abercrombie de 1944, establece una matriz de densidades residenciales de calidad que se expresa en viviendas por hectárea y dormitorios por hectárea para tener en cuenta las diferencias de tamaño de hogar posibles y la accesibilidad en transporte público, estableciendo una horquilla entre las 35 y las 450 viviendas por hectárea (entre 150 y 1100 habitaciones/hectárea). Permite un juego flexible entre la diversidad de tipologías arquitectónicas y la garantía de horquillas de densidad vinculadas a la provisión de servicios esenciales como la movilidad. 
Tabla 7. Regulación de la densidad residencial. Plan de Londres 2016

\begin{tabular}{|c|c|c|c|}
\hline & $\begin{array}{c}\text { Public Transport } \\
\text { Accessibility Level (PTAL) }\end{array}$ & Setting & $\begin{array}{c}\text { Public Transport } \\
\text { Accessibility Level (PTAL) }\end{array}$ \\
\hline & 0 to 1 & 2 to 3 & 4 to 6 \\
\hline Suburban & $150-200 \mathrm{hr} / \mathrm{ha}$ & $150-250 \mathrm{hr} / \mathrm{ha}$ & 200-350 hr/ha \\
\hline $3.8-4.6$ hr/unit & $35-55 \mathrm{u} / \mathrm{ha}$ & $35-65 \mathrm{u} / \mathrm{ha}$ & $45-90 \mathrm{u} / \mathrm{ha}$ \\
\hline 3.1-3.7 hr/unit & $40-65 \mathrm{u} / \mathrm{ha}$ & $40-80 \mathrm{u} / \mathrm{ha}$ & 55-115 u/ha \\
\hline 27-3.0 hr/unit & $50-75 \mathrm{u} / \mathrm{ha}$ & 50-95 u/ha & $70-130$ u/ha \\
\hline Urban & $150-250 \mathrm{hr} / \mathrm{ha}$ & $200-450 \mathrm{hr} / \mathrm{ha}$ & $200-700 \mathrm{hr} / \mathrm{ha}$ \\
\hline $3.8-4.6$ hr/unit & $35-65 \mathrm{u} / \mathrm{ha}$ & $45-120$ u/ha & 45-185 u/ha \\
\hline 3.1-3.7 hr/unit & $40-80 \mathrm{u} / \mathrm{ha}$ & 55-145 u/ha & $55-225$ u/ha \\
\hline 27-3.0 hr/unit & $50-95 \mathrm{u} / \mathrm{ha}$ & 70-170 u/ha & $70-260$ u/ha \\
\hline Central & $150-300 \mathrm{hr} / \mathrm{ha}$ & $300-650 \mathrm{hr} / \mathrm{ha}$ & $650-1100 \mathrm{hr} / \mathrm{ha}$ \\
\hline $3.8-4.6$ hr/unit & $35-80 \mathrm{u} / \mathrm{ha}$ & $65-170 \mathrm{u} / \mathrm{ha}$ & $140-290 \mathrm{u} / \mathrm{ha}$ \\
\hline 3.1-3.7 hr/unit & $40-100 \mathrm{u} / \mathrm{ha}$ & $80-210 \mathrm{u} / \mathrm{ha}$ & $175-355$ u/ha \\
\hline 2.7-3.0 hr/unit & $40-100 \mathrm{u} / \mathrm{ha}$ & $100-240 \mathrm{u} / \mathrm{ha}$ & $215-405 \mathrm{u} / \mathrm{ha}$ \\
\hline
\end{tabular}

Fuente: London Plan 2016 Sustainable residential quality (SRQ) density matrix (habitable rooms and dwellings per hectare).

\section{Poner a las personas primero: la ciudad cercana}

El crecimiento exponencial del parque de automóviles privados está asociado a los procesos de dispersión territorial y al mismo tiempo se retroalimenta de las necesidades de movilidad individual generadas por los modelos de ocupación territorial de muy baja densidad. Existe un amplio consenso en la comunidad científica en entender que el impacto de la movilidad urbana sustentada en el predominio del automóvil privado es insostenible en relación con dos de las variables claves en el concepto contemporáneo de calidad de vida: la preservación del medio ambiente urbano, ahorro energético y la salud. Respecto al primer aspecto, la movilidad urbana basada en el automóvil privado es ineficiente por cuanto demanda un alto consumo de energía por kilómetro de viaje y adicionalmente supone una desproporcionada ocupación del espacio público urbano, en vías de circulación y espacio para aparcamiento, tanto si tomamos como referencia comparativa los modos de transporte colectivo de mayor capacidad, como en comparación con otros modos de transporte compartido con o sin conductor. En relación con la salud, la movilidad cautiva del automóvil está asociado al sedentarismo, una de las causas acreditadas del dramático crecimiento de las enfermedades cardiovasculares y obesidad, así como el deterioro de la calidad del aire en el medio urbano, asociado a las enfermedades respiratorias y cáncer.

El análisis de la Muestra de Ciudades elaborado por UN-HABITAT (2016) evidencia también una reducción ininterrumpida de la proporción de espacio urbano destinado a calles a lo largo de los últimos cien años, pasando de alcanzar el 25\% de la superficie urbanizada a comienzos del siglo XX a una extensión del $21 \%$ en la actualidad. El $48 \%$ de las ciudades destina menos del 20\% del suelo urbano a calles y el acceso peatonal a las vías arteriales también se ha visto reducido, generando para la mayoría de los nuevos habitantes una demanda cautiva de la movilidad motorizada bien de transporte público o de automóvil privado. En ciudades como Madrid Barcelona en torno al $70 \%$ del espacio total de las calles está dedicado al automóvil. El automóvil urbano es asimismo responsable

ACE, 15 (4.3) CC BY-ND 3.0 ES | UPC Barcelona, España | Hay que Defender la Ciudad: De la Distopía a la Ciudad 31 Abierta. DOI: http://dx.doi.org/10.5821/ace.15.43.9518 
en gran medida de los problemas de congestión urbana y el consiguiente despilfarro en términos de tiempo y consumo de energía. Frente a estos problemas y desde una perspectiva global es necesario promover una movilidad urbana orientada a reducir a corto plazo la movilidad forzosa motorizada especialmente en los viajes pendulares residencia-trabajo-residencia- priorizando alternativamente la movilidad peatonal y los medios de transporte colectivos o compartidos respetuosos con el medio ambiente. A medio y largo plazo será también necesario cambiar los modos de organización urbana hoy basados en la segregación funcional en base a la regulación de los usos del suelo y social, en base a la distribución geográfica de los valores del suelo.

La cultura arquitectónica moderna se ha formado sobre el concepto de ciudad abierta, entendida en el doble sentido de extensión urbana ilimitada y liberación de la arquitectura de las constricciones contextuales de la ciudad tradicional (Mumford, 2002). Ha sido analizado el vínculo entre ese paradigma y la percepción de la ciudad como un organismo enfermo que es necesario refundar desde el punto de vista arquitectónico y social (Le Corbusier, 1945). La realidad de las nuevas metrópolis no responde tanto a estos principios cuanto, a una lógica pragmática de la fragmentación espacial en sintonía con la aceleración del ciclo de consumo, expresada en la fugacidad, provisionalidad y superficialidad de lo construido. La idea de ciudad abierta, defendida entre otros por Richard Sennett (2018), es muy distinta. Se concibe porosa e incompleta, es decir susceptible de una transformación y recreación constante sobre la base de las necesidades reales de sus habitantes. Sugiere, asimismo, la necesidad de promover densidades razonables que permitan la mezcla de usos (residenciales, dotacionales y actividades económicas), la variedad y cohesión social, favoreciendo la movilidad peatonal como medio preferente de acceso a los servicios cotidianos (UN-Habitat, 2015 y 2018 ; Wolfrum et al. 2018).

El contexto del confinamiento ha motivado que este debate teórico y profesional se transformara en público y político en un breve periodo de tiempo. El concepto de ciudad de los 15 minutos difundido por la alcaldesa de París Anne Hidalgo no es como tal innovador, pero tiene la capacidad de visibilizar de manera accesible la necesidad de volver a sintonizar las relaciones espacio/tiempo en el proyecto de la ciudad. La relación entre ambos conceptos se hizo visible durante el periodo de la cuarentena domiciliaria para el conjunto de la ciudadanía en base a la traumática experiencia de las limitaciones en el uso del espacio público impuestas por preservación de la distancia social y la distribución de franjas horarias según edades y propósitos.

La idea de la unidad vecinal, el barrio o neighborhood unit está asociada en la cultura urbanística anglosajona a la experiencia de la pérdida de homogeneidad identidad que históricamente había caracterizado a los barrios se componen la ciudad y a la necesidad de ofrecer una alternativa orgánica desde el planeamiento racional. La ciudad europea tradicional se organizaba como agregación de barrios autónomos con identidad e historia propia y no desde la fragmentación espacial o la disgregación territorial que caracterizarían más tarde a la ciudad industrial y post industrial. Asimismo, durante el periodo de formación de las grandes de las ciudades norteamericanas los barrios asumieron una identidad basada en la comunidad de origen geográfico o racial, lenguaje, religión...y más tarde las distinciones de clase.

La idea de la unidad vecinal, como señala Arthur Gallion (1950) no es un fenómeno sociológico ni una teoría particular en la esfera de las ciencias sociales. Es simplemente un entorno en el cual una madre sabe que su hijo no tendrá que cruzar calles de tráfico en su camino a la escuela, que estará a una amable distancia peatonal de su casa. La unidad vecinal reorganiza la distribución del tejido residencial desde la primacía del acceso peatonal de los servicios y equipamientos esenciales empezando por la escuela- y el transporte público. Con diversas modulaciones paramétricas, la idea está presente en la propuesta de Clarence Perry para el Plan Regional de Nueva York y su entorno de 1929 así como en los Planes de Chicago de 1942, de Abercrombie para el Greater London Plan de 1944 (Monclús, 1998) o de Le Corbusier y Sert para Bogotá (Tarchópulos, 2014).

ACE, 15 (4:3) CC BY-ND 3.0 ES | UPC Barcelona, España | Hay que Defender la Ciudad: De la Distopía a la Ciudad 32

Abierta. DOI: http://dx.doi.org/10.5821/ace.15.43.9518 
El esquema de Clarence Stein para el Plan de Radburn (Figura 16) muestra la agrupación de tres unidades vecinales servidas por una escuela secundaria y dos centros comerciales tiene un radio de distancia máximo de una milla. Cada una de estas unidades sí organiza entorno a la escuela primaria y a los comercios de proximidad en un radio máximo de media milla como diseñándose las calles de manera que se impide el tráfico de paso.

Figura 16. Plan General de Radburn mostrando las unidades vecinales articuladas en entornos de media milla de radio

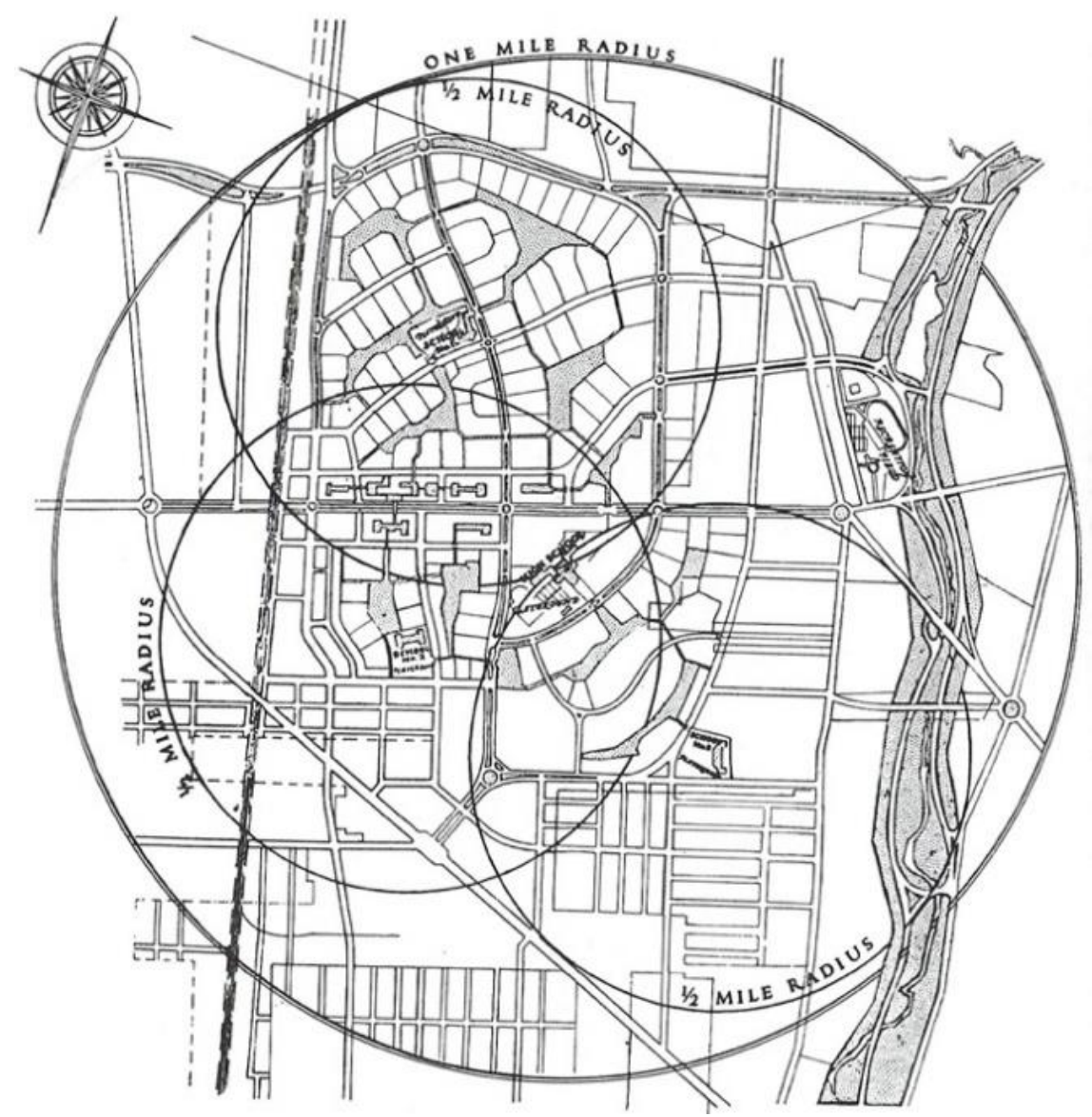

Fuente: Clarence S. Stein 1950. Toward New Towns for America.

Para que funcione el juego entre los dominios público y privado es preciso que la calle, además de elemento generador de la ordenación, continúe desempeñando un papel significativo en cuanto elemento de relación tanto entre las personas como entre las actividades. Una condición necesaria para lograr la animación de la calle es contar con una estructura residencial y de actividades de cierta densidad. Sin embargo, es frecuente constatar que la simplificación de las tipologías de espacios públicos, unida a la carencia de una densidad edificatoria suficiente para garantizar un umbral mínimo de actividad, tienen como consecuencia del abandono de la calle y su transformación en un espacio deteriorado e inseguro.

El informe Towards an Urban Renaissance (1999) elaborado por el Urban Task Force, presidido por Richard Rogers actualizó el modelo de Unidad Vecinal incorporando los objetivos de intensidad y uso mixto. El documento considera que uno de los principales atractivos de la vida urbana es la proximidad al lugar de trabajo, comercio y servicios esenciales en la esfera social, educativa y de ocio. Entendiendo que un buen diseño urbano debe favorecer que la mayor parte de las personas puedan

ACE, 15 (4.3) CC BY-ND 3.0 ES | UPC Barcelona, España | Hay que Defender la Ciudad: De la Distopía a la Ciudad 33 Abierta. DOI: http://dx.doi.org/10.5821/ace.15.43.9518 
vivir cerca de tales servicios gracias a la integración de usos a la escala del barrio, de la calle, de la manzana o en la propia distribución vertical de los edificios. La figura 17 ejemplifica como integrar en las unidades vecinales una amplia elección de servicios cercanos a las áreas residenciales sin crear áreas monofuncionales de comercio, negocios o vivienda. En síntesis: la ciudad de los 15 minutos.

Figura 17. Componentes claves de la unidad vecinal integrada de uso mixto

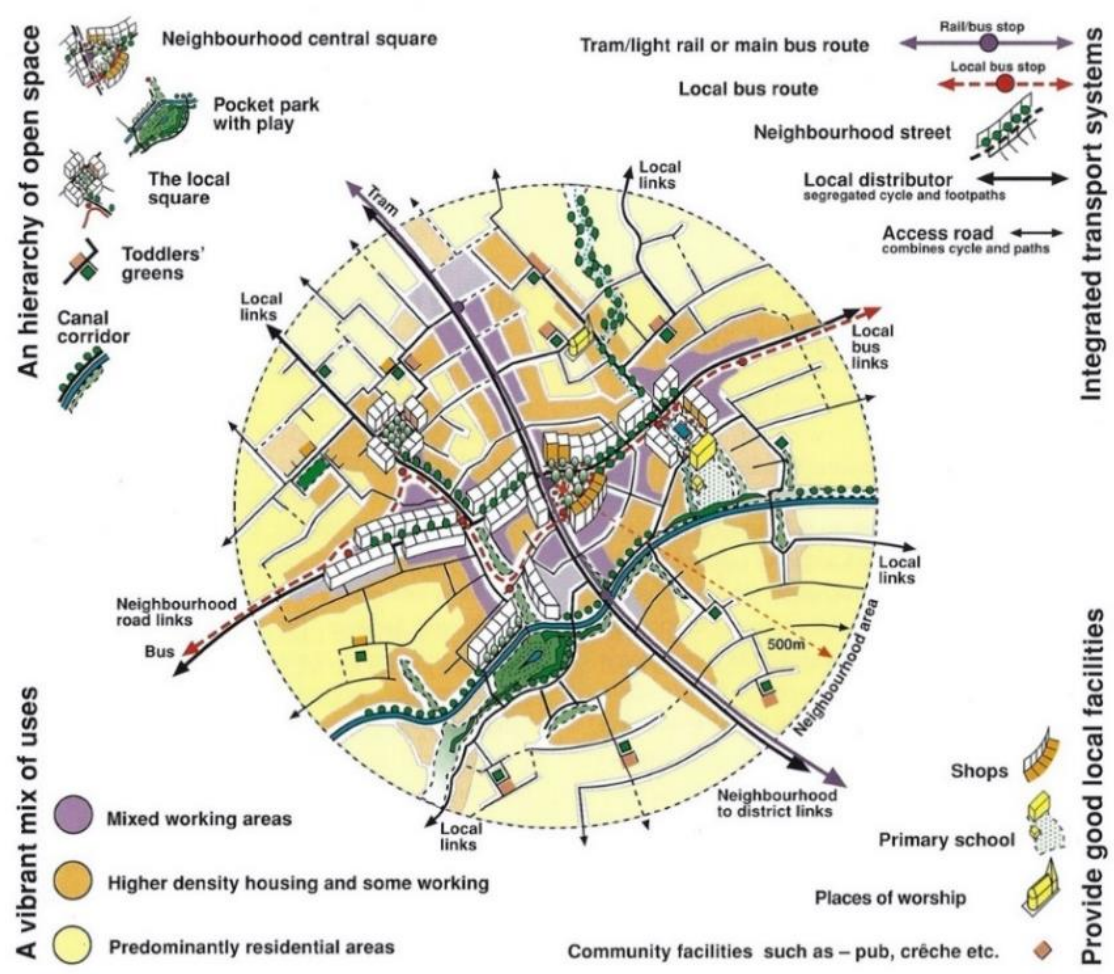

Fuente: Department of The Environment, Transports and The Regions 1999. Towards an Urban Renaissance. (Andrew Wright Ass).

El Proyecto Madrid Centro (Ezquiaga, Herreros y Pérez Arroyo, 2011, Figuras 13, 18 y 19) propuso una alternativa, radical pero susceptible de implementarse de manera incremental y con bajo coste: repensar la organización del espacio construido desde la óptica de una nueva célula urbana. A partir de la discriminación de los tráficos de paso y de los tráficos exclusivos para residentes se consigue la creación de áreas ambientales en las que es factible invertir la desigual distribución del uso de la calle entre el automóvil y el ciudadano. la estructura de calles principales garantiza el acceso mediante transporte público y automóvil a la totalidad de la trama urbana, pero la malla secundaria de calles de menor sección admite la limitación del acceso a residentes y permite crear una red complementaria en la que el confort peatonal, la accesibilidad ciclista, la arborización y las actividades económicas y comerciales se conviertan en los elementos principales. La nueva célula urbana constituye el ámbito coherente para reorganizar el acceso de los ciudadanos a los servicios y dotaciones de proximidad, instrumento clave en la corrección de las desigualdades urbanas.

El transporte público es un activo irrenunciable de las grandes ciudades. Su preservación y eficiencia es un gran reto mientras dure la situación de emergencia sanitaria. Para conseguirlo es clave su adaptación flexible: mayor nivel de frecuencia y extensión de la red para facilitar el mantenimiento de la distancia física y rediseño del conjunto del sistema para que no sea percibido como una amenaza para el usuario (Bliss et al. 2020; O 'Sullivan, 2020a y 2020b).

ACE, 15 (4.3) CC BY-ND 3.0 ES | UPC Barcelona, España | Hay que Defender la Ciudad: De la Distopía a la Ciudad 


\section{ACE Architecture, City and Environment}

E-ISSN 1886-4805

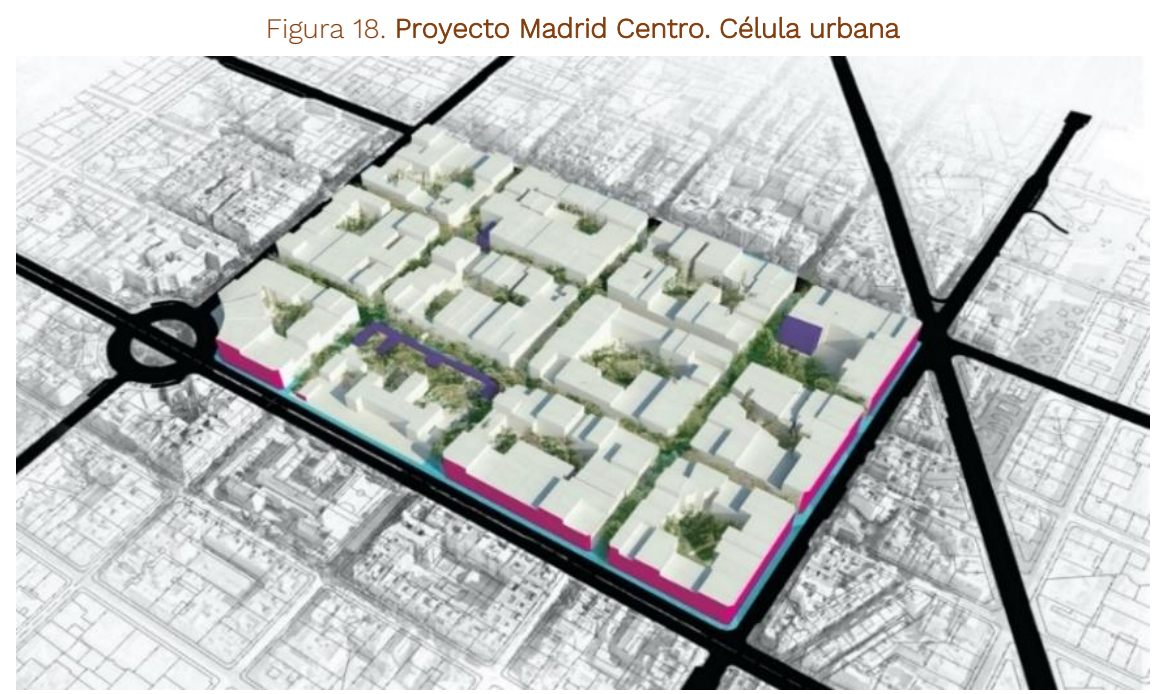

Fuente: José María Ezquiaga, Juan Herreros, Salvador Pérez Arroyo. Proyecto Madrid Centro 2011.

Figura 19. Proyecto Madrid Centro. Una nueva ordenación urbana

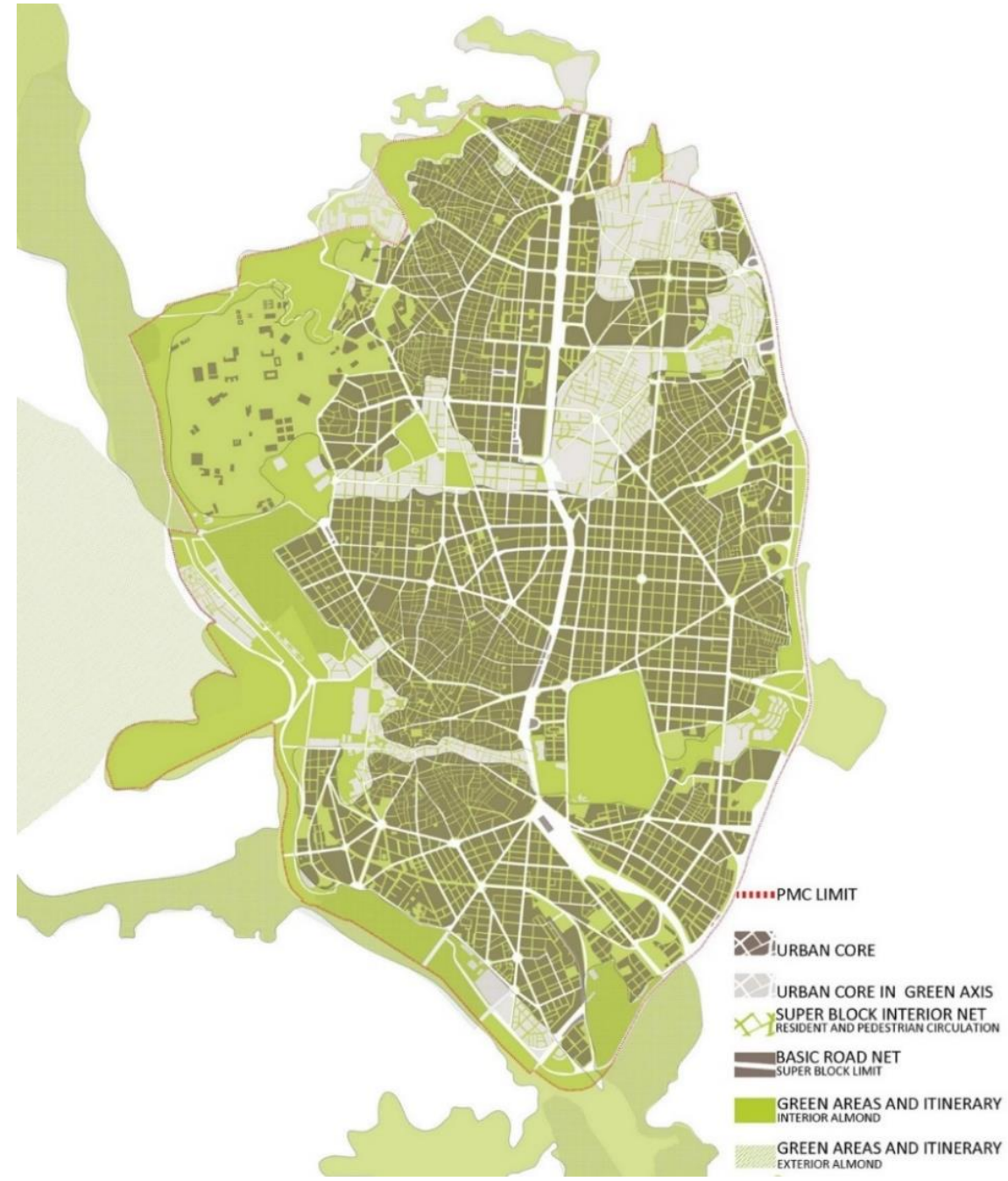

Fuente: José María Ezquiaga, Juan Herreros, Salvador Pérez Arroyo. Proyecto Madrid Centro 2011.

ACE, 15 (4:3) CC BY-ND 3.0 ES | UPC Barcelona, España | Hay que Defender la Ciudad: De la Distopía a la Ciudad

Abierta. DOI: http://dx.doi.org/10.5821/ace.15.43.9518 
El ecosistema de la movilidad en una ciudad contemporánea se ha hecho mucho más variado y complejo de lo que estamos acostumbrados a considerar. Desde la perspectiva de las políticas de movilidad es necesario asumir esta realidad y promover una oferta amplia y variada de modos de transporte motorizados y no motorizados que racionalice el acceso indiscriminado de los vehículos al Centro sin poner en crisis la accesibilidad esencial. En las áreas de menor densidad aparece la oportunidad de implementar sistemas de transporte a la demanda y a medio y largo plazo sistemas de vehículo autónomo eléctrico de servicio público. Como alternativa al automóvil privado estos sistemas permiten modular la dimensión de los vehículos y adaptarla a los requerimientos de tejidos urbanos en los que la menor densidad de población haga inviable económicamente la implementación de sistemas colectivos de gran capacidad y puede articularse con sistemas de alta capacidad que conecten intercambiadores de transporte distribuidos en las periferias más alejadas con el corazón de la ciudad.

\section{De la planificación espacial a la gestión del uso social del tiempo}

Quizás lo que mejor caracteriza la condición urbana contemporánea sea la multiplicidad de realidades y la sobre abundancia de acontecimientos. La ciudad no es fruto de una narrativa coherente, sino resultado de bifurcaciones y paradojas. Melvin Webber (1964) fue pionero en formular las consecuencias espaciales del creciente desarrollo de dominios de relación no referidos a lugares determinados. Las nociones actuales de comunidad virtual o ciberespacio han llevado esta idea a sus últimas consecuencias. En 1972 el arquitecto Kevin Lynch se hizo la pregunta: ¿De qué tiempo es este lugar? Intentando trasladar al ámbito del diseño urbano y la arquitectura la evidencia del tiempo en el mundo físico, la naturaleza, los ritmos biológicos o la experiencia subjetiva, buscando las señales temporales y la estética del tiempo en la ciudad. Pero ha sido el sociólogo británico Anthony Giddens (1990) quien ha identificado la escisión espacio/temporal como condición del dinamismo extremo que caracteriza a la modernidad.

La planificación del tiempo puede enfocarse desde dos dimensiones complementarias. La primera de orden epistemológico entiende la compleja realidad de la ciudad contemporánea como resultado de la interacción entre un espacio de flujos, regido por la lógica del tiempo y un espacio de lugares, regido por la lógica de la localización.

Los cambios en las formas de producción, organización del consumo y movilidad de capitales, personas y bienes, están cambiando de manera profunda al carácter de las ciudades y lo global y lo local se encuentran conectados de manera inimaginable en las sociedades tradicionales (Burdett \& Sudjic, 2011). El salto en las tecnologías de comunicación y la estrecha interrelación de los mercados genera que acontecimientos generados en centros de decisión lejanos afecten rutinariamente a las vidas de millones de personas (Sassen, 1991). Tal como la pandemia del COVID19 ha evidenciado. Como resultado de la nueva economía basada en la información y el conocimiento, la expresión contemporánea de la condición urbana asume una multiplicidad de disposiciones espaciales, en abierta ruptura con las configuraciones tradicionales. Como ya ha sido analizado, en el ámbito espacial, todo ello se traduce en la obsolescencia de las expresiones cívicas convencionales de lo público: avenidas, parques, plazas, equipamientos e infraestructuras, y su sustitución por ámbitos privados capaces de activar y congregar de manera flexible las diversas formas de vida colectiva, particularmente en torno a la movilidad, el consumo, el entretenimiento y los acontecimientos deportivos y culturales. (Ezquiaga, 2008 y 2018)

En consecuencia, la gobernanza urbanística de esta nueva realidad es difícil de sustentar sobre diagnósticos y regulaciones que sólo atienden a una parte muy limitada de los procesos económicos y sociales que impulsan esta transformación. (Ascher, 2001; Healey, 2007; Carta, 2014). Pero hay otra dimensión más cercana del tiempo, que podemos denominar fenomenológica. La ciudad está llena

ACE, 15 (4:3) CC BY-ND 3.0 ES | UPC Barcelona, España | Hay que Defender la Ciudad: De la Distopía a la Ciudad 36 Abierta. DOI: http://dx.doi.org/10.5821/ace.15.43.9518 


\section{ACE Architecture, City and Environment}

de señales de tiempo y de patrones que organizan nuestra vida cotidiana (Duch, 2015). El ritmo de las horas punta de tráfico y movilidad, los horarios que rigen cada una de las actividades, el propio tiempo libre y el ocio (figura 20), hasta las micro temporalidades de los horarios de transporte, de la regulación de aparcamiento, semáforos etc.

Figura 20. Nueva York Bryan Park, hora del almuerzo en un día laborable

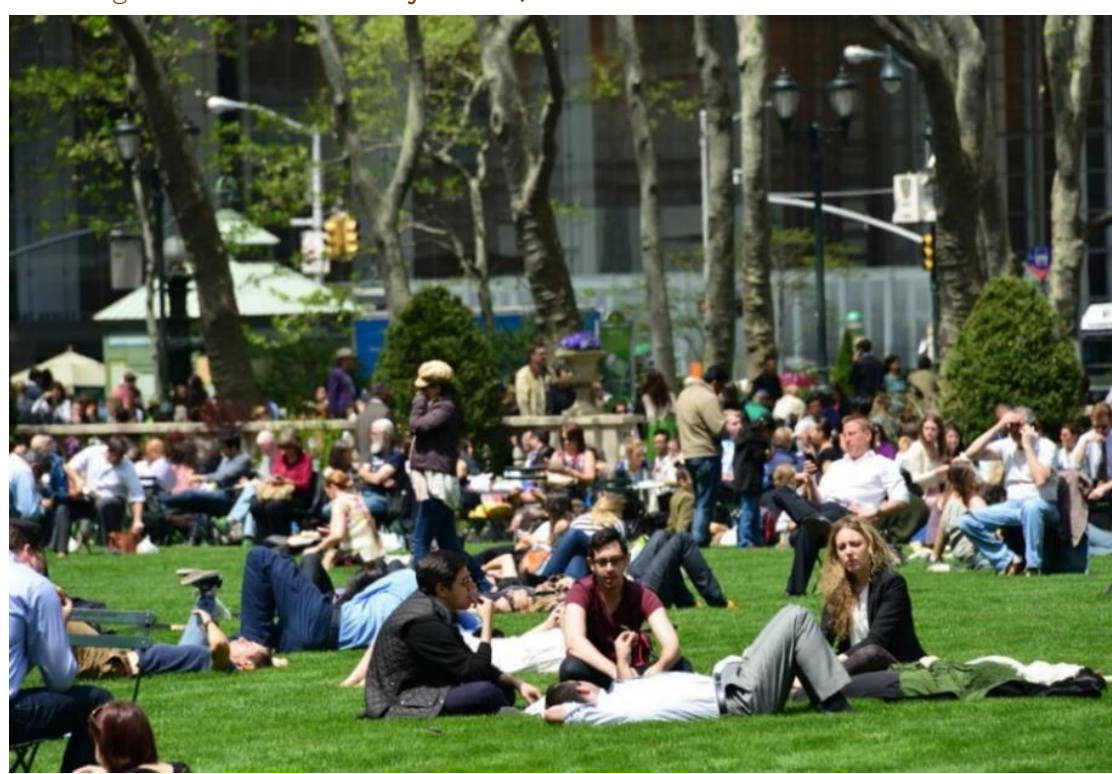

Fuente: José María Ezquiaga.

Durante la emergencia sanitaria nos hemos visto sometidos a una regulación horaria en la utilización del espacio público. Esta circunstancia nos ha hecho por primera vez conscientes de sus limitaciones y de la importancia de su calidad. Pero el salto cualitativo debe hacerse en la esfera de las relaciones laborales y la movilidad. El achatamiento de las horas punta en las infraestructuras de transporte público y tráfico privado no sólo dependerá de la mejora de las infraestructuras, sino en mayor medida de una gestión inteligente del tiempo, donde las nuevas herramientas de explotación de big data pueden encontrar una fructífera aplicación (Drewe, 2005).

La primera medida debiera ser el escalonamiento flexible de los horarios comerciales, escolares y laborales; atendiendo a la localización geográfica. Esta medida puede complementarse con la permanencia duradera del teletrabajo en empresas y administraciones en combinación con el trabajo presencial en determinadas horas del día, o días de la semana.

Finalmente, la definitiva superación de la zonificación debe dar paso una mezcla equilibrada de actividades económicas, ocio y residencia en cada una de las piezas del tejido urbano. Durante el confinamiento ha sido frecuente la transformación de los hogares en viviendas productivas en las que han convivido trabajo y cuidados, conexión social e intimidad personal. Esta experiencia marca la pauta de una transformación muy interesante de la arquitectura residencial y la ciudad.

A pesar de que el sistema legal de planeamiento en España y la mayoría de los países desarrollados se sustenta en el paradigma de la ciudad clasificada, zonificada y construida desde políticas sectoriales (urbanismo, medio ambiente, transporte, dotaciones públicas...) hay margen suficiente para promover una ciudad más compleja, orientada hacia la convivencia armónica de una amplia variedad de usos del suelo y de los propios inmuebles y a la disponibilidad de los servicios y equipamientos esenciales en el entorno más cercano a la vivienda. Lamentablemente las regulaciones urbanísticas de los Planes municipales españoles permanecen ancladas, con pocas 
excepciones, en la radical separación de usos del suelo. Entendiendo esta transformación del espacio residencial como una amenaza para el equilibrio funcional de las ciudades y no como el primer paso para alcanzar un tejido urbano más complejo y menos dependiente de la movilidad obligada (Teran, 1978; Ezquiaga,1998).

Las denominadas home occupations, negocios operados por un residente como uso complementario en su vivienda principal, constituyen, conforme al US Census Bureau la mitad de todas las empresas de Estados Unidos. En 2020, cerca de 8 millones de personas trabajan principalmente desde su casa y su número no ha dejado de crecer desde 1980. Vale la pena recordar que algunas de las más emblemáticas compañías como Disney, Apple o Google arrancaron en su momento como home occupations (Yuko, 2020). Como señala la American Planning Association los avances en tecnología de la información han creado y ampliado las oportunidades para las viviendas productivas: el acceso a Internet de banda ancha hace posible el trabajo desde oficinas remotas y las plataformas de comercio electrónico y las plataformas digitales de logística de la distribución permiten la conexión entre la vivienda productiva y sus clientes espacialmente alejados.

El conflicto con las normativas urbanísticas no es exclusivo de nuestro país, en Norteamérica las regulaciones del zoning más tradicionales están orientadas a la promover la separación radical de los usos del suelo y muchas comunidades defienden el carácter exclusivamente residencial de los barrios unifamiliares consolidados. Es necesario por tanto hilar fino para encontrar un equilibrio entre los beneficios que desde una visión global aporta esta nueva tipología y los eventuales impactos que pueda generar sobre el vecindario más próximo.

Complementariamente, la extensión del teletrabajo impulsará tendencias a un cambio radical en la concepción de los espacios de trabajo (Holder, 2020). En las grandes ciudades globales son ya muchas las compañías multinacionales que promueven que al menos un día la semana sus empleados desarrollen la jornada laboral en su casa. Si el día elegido pudiera ser flexible y se distribuyera homogéneamente -es decir no todos los trabajadores eligieran el viernes- tan sólo con esta medida se reducirían 20\% las demandas de movilidad obligada por motivos laborales en el sector de oficinas.

Será necesario imaginar la complementariedad entre defender la presencia de las actividades productivas en el tejido urbano con una más compleja utilización de los suelos productivos. Defendiendo la integración de la más amplia presencia de actividades económicas (tradicionales e innovadoras) dotacionales y comerciales tanto en los tejidos residenciales como en los de especialización productiva. Este mestizaje constituye la base de la complejidad urbana y el caldo de cultivo de la atracción de actividades innovadoras en las esferas tecnológica, cultural y artística y abrirá una nueva dimensión a la reconversión y transformación de la ciudad.

\section{Conclusiones}

La experiencia del confinamiento frente al COVD19 ha desestabilizado profundamente el espacio público y las infraestructuras vitales de nuestras ciudades, abriendo la posibilidad de impulsar tendencias disruptivas con la visión convencional de la gobernanza urbana.

\section{Defender el equilibrio entre densidad urbana y habitabilidad. La ciudad "mediterránea"}

La densidad está asociada a la noción de intensidad. Sabemos desde Simmel que este es uno de los rasgos más esenciales de la ciudad moderna y la base sobre la que se sustenta la acumulación de conocimiento, el intercambio de ideas y la creación.

ACE, 15 (4:3) CC BY-ND 3.0 ES | UPC Barcelona, España | Hay que Defender la Ciudad: De la Distopía a la Ciudad

Abierta. DOI: http://dx.doi.org/10.5821/ace.15.43.9518 
Una de las más urgentes cuestiones que las ciudades deben afrontar es resolver la contradicción entre la densificación entendida como limitación racional del consumo de territorio y la dispersión territorial, que en el contexto de la pandemia parece a asociarse mejor al distanciamiento social. Sin embargo, hay razones de largo aliento que aconsejan seguir defendiendo el modelo de ciudad mediterránea: densa, continua y compacta (Ezquiaga, 2019). La intensidad de la interacción social estimula la innovación y la creación en las esferas económica, científica y cultural. Desde el punto de vista ambiental la densidad es clave para reducir de la huella urbana, el consumo energético y las emisiones de carbono. Hace posible una movilidad limpia, prioritariamente peatonal en las cortas distancias y un transporte público eficiente para la movilidad obligada a escala metropolitana.

\section{Poner a las personas primero. La ciudad cercana}

Las medidas de distanciamiento social durante la emergencia sanitaria han fortalecido la conciencia del valor de los vínculos entre personas y grupos diversos. Esto ha evidenciado las ventajas de los lugares donde la gente vive suficientemente cerca para acceder peatonalmente a los servicios que necesita y los beneficios colaterales de la reducción de la movilidad: la visible mejora de la calidad del aire y la reducción del ruido. Por otra parte, ha hecho patente el conflicto entre un espacio viario diseñado al servicio del automóvil, las necesidades de la movilidad peatonal y las demandas de las actividades económicas a pie de calle.

Se hace necesario un nuevo contrato cívico en favor de la prioridad peatonal y la sensibilidad hacia las nuevas necesidades de una población urbana cada vez más diversa. No se trata de ampliar las aceras para hacer posible el mantenimiento de la distancia de seguridad, cuanto de redefinir el papel del espacio público desde nuevos criterios. Dar prioridad al confort y la seguridad peatonal. Activar la vitalidad e intensidad de la calle estimulando la más amplia variedad de actividades. Promover una re-naturalización de la ciudad sustentada sobre una infraestructura verde multiescalar que cuide desde la más diminuta esquina de barrio hasta los grandes espacios naturales y rurales de escala regional.

\section{La ciudad compleja. Las viviendas productivas}

La definitiva superación de la zonificación debe dar paso a la mezcla intencionada de actividades económicas, ocio y residencia en cada una de las piezas del tejido urbano. Las viviendas productivas del confinamiento, en las que han convivido el trabajo y los cuidados, la conexión social y la intimidad personal, son la vanguardia de una transformación muy profunda de la arquitectura residencial. Complementariamente, la extensión del teletrabajo impulsará las tendencias a un cambio radical en la concepción de los espacios de trabajo y abrirá nuevas oportunidades para la reinvención y transformación de los centros de negocios.

\section{La ciudad abierta. Una gestión inteligente del tiempo}

Proyectar la ciudad visible es una herramienta insuficiente para gestionar la complejidad urbana contemporánea. Durante la emergencia sanitaria nos hemos visto sometidos a una regulación horaria de la utilización del espacio público. Esta circunstancia nos ha hecho conscientes de sus limitaciones y la importancia de su calidad, pero también de los ritmos y patrones temporales que organizan nuestra vida cotidiana. La mejora de la movilidad no sólo dependerá de la ampliación de la capacidad de las infraestructuras, sino en mayor medida de una gestión inteligente del tiempo. Pero el cambio más profundo debe operarse en la renovación de la dialéctica entre las esferas de lo público y lo privado, incorporando la dimensión social y la experiencia temporal al proyecto espacial de la ciudad.

Conflicto de intereses: El autor declara que no hay conflicto de intereses.

ACE, 15 (4:3) CC BY-ND 3.0 ES | UPC Barcelona, España | Hay que Defender la Ciudad: De la Distopía a la Ciudad 39 Abierta. DOI: http://dx.doi.org/10.5821/ace.15.43.9518 


\section{Bibliografía}

Ali, S. H. \& Keil, R. (2006). Global cities and the spread of infectious disease: the case of Severe Acute Respiratory Syndrome (SARS) in Toronto, Canada. Urban Studies, 43(3), 491-509. Recuperado de https://journals.sagepub.com/doi/pdf/10.1080/00420980500452458

Alphand, Adolph (1867). Les Promenades de Paris. Paris. Francia: Rothschild. (Reedición New York. United States: Princeton Architectural Press, 1984)

Angel, Sh. et al. (2012). Atlas of Urban Expansion. Cambridge, Massachusetts, United States: Lincoln Institute of Land Policy.

Angel, Sh. et al. (2015). Planeta de Ciudades. Cambridge, Massachusetts. United States: Lincoln Institute of Land Policy y Universidad del Rosario.

Badger, E. (24 de marzo de 2020). Density Is Normally Good for Us. That Will Be True After Coronavirus, Too. The New York Times.

Barros, J. y Ezquiaga, J.M. (2019). Dinámicas de transformación del tejido urbano residencial de Madrid: trama residencial versus trama urbana. Trabajo presentado en el Cuarto Congreso ISUF-H. Forma Urbis y Territorios Metropolitanos. Barcelona, España. 2020.

Barton, H. y Tsouru, C. (2010). Healthy Urban Planning. World Health Organization. London, United Kingdom: Spon.

Barton, H. (2017). City of Well-being. A radical guide to planning. New York, United States: Routledge.

Bassett, M.T. (15 de mayo de 2020). Just Because You Can Afford to Leave the City Doesn't Mean You Should. The New York Recuperado de https://www.nytimes.com/2020/05/15/opinion/sunday/coronavirus-cities-density.html

Bassols Coma, M. (1973). Génesis y evolución del Derecho Urbanístico español (1812-1956). Madrid, España: Montecorvo.

Benévolo, L. (1963). Le Origini dell 'Urbanistica Moderna. Roma, Itlaia: Laterza. (Edición española. 1979. Madrid, España: Blume.)

Bliss, L.; Lin, Jeremy C.F., \& Patino, M. (18 de junio de 2020). Pandemic Travel Patterns Hint at Our Urban Future. Bloomberg CityLab. Recuperado de https://www.bloomberg.com/graphics/2020coronavirus-transportation-data-cities-traffic-mobility/

Bloomberg CityLab (22 de junio de 2020). How the Coronavirus Recovery Is Changing Cities. Bloomberg CityLab. Recuperado de https://www.bloomberg.com/features/2020-city-in-recovery/

Brenner, N. (2014). Implosions/Explosions. Towards a study of planetary urbanization. Berlín, Alemania: Jovis.

Burdett, R. \& Sudjic, D. (Eds.) (2011). Living in the endless city. The Urban Age Project by the London School of Economics and Deutsche Bank's Alfred Herrhausen Society. London, United Kingdom: Phaidon.

Carta, M. (2014). Reimagining Urbanism: Vision, Paradigms, Challenges and Actions for better future. New York, United States: Actar Pulishers.

ACE, 15 (4.3) CC BY-ND 3.0 ES | UPC Barcelona, España | Hay que Defender la Ciudad: De la Distopía a la Ciudad 40 Abierta. DOI: http://dx.doi.org/10.5821/ace.15.43.9518 
Centres of Excelence (11 de junio 2020). Covid-19 challenges New York's future. Cities around the world, take heed. The Economist. Recuperado de https://www.economist.com/briefing/2020/06/11/covid-19-challenges-new-yorks-future

Cerdá, I. (1867). Teoría general de la urbanización y aplicación de sus principios y doctrinas a la reforma y ensanche de Barcelona. Madrid, España: Imprenta Española. Dos volúmenes. Reimpresión facsímil en Estapé (1968).

Chadwick, E. (1842). Report on the sanitary condition of the labouring population of Great Britain to the poor law commissioners, 1842. HL v26.

Colomina, B. (2019). X-ray Architecture. Zurich, Suiza: Lars Muller Publishers.

Chicote, C. (1914). La vivienda insalubre en Madrid. Memoria presentada al excelentísimo Señor Vizconde de Eza Alcalde Presidente por El Director Jefe del Laboratorio Municipal Doctor César Chicote. Madrid: España. Imprenta Municipal.

Crawford, M. (2011). Burring the Boundaries. Public Space and Private Life. En Readings in Urban Theory. (pp. 342-355). New Jersey, United States: Wiley-Blackwell.

Department of the Environment, Transports and the Regions (1999). Towards an Urban Renaissance. London, Reino Unido: E. \& F.N. Spon Publisher.

Diez Medina, C. y Monclús, J. (Eds.) (2017). Visiones Urbanas. De la cultura del plan al urbanismo paisajístico. Madrid, España: Abada editors.

Drewe, P. (2005). Time in Urban Planning and Design in the ICT Age. En Hulsbergen, E.; Klaasen, I. \& Kriens I. Shifting Sense. Looking Back to the Future in Spatial Planning (pp.197-211). Amsterdam. Holanda: Techne Press

Duch, L. (2015). Antropología de la ciudad. Barcelona, España: Herder Editorial, S.L.

Evans, R. (1980). Il contagio dell 'immoralità. Casa e familia nella Londra dell 'Ottocent. En Morachiello, P \& Teyssot, G. Le macchine imperfette. (pp. 268-292). Roma, Italia: Officina Edicioni.

Ezquiaga, J.M. (1998). ¿Cambio de Estilo o cambio de Paradigma? Reflexiones sobre la Crisis del Planeamiento Urbano. Urban, 2, 7-36. Recuperado de http://polired.upm.es/index.php/urban/article/view/187

Ezquiaga, J.M. (2008). Horizontes postmetropolitanos. En De la ciudad antigua a la cosmópolis, Cuadernos de la Fundación Botín, 12. 207-228. Observatorio de Análisis de Tendencias, Santander.

Ezquiaga, J.M. (2018). El porvenir de una ilusión. Planificar en un contexto de indeterminación e incertidumbre. Ponencia inaugural en el // Congreso Internacional Zaragoza ISUF-H 2018 Ciudad y formas urbanas. Perspectivas transversales (p. 11-23). Zaragoza, España: Universidad de Zaragoza.

Ezquiaga, J.M. (2019). La Nueva Agenda Urbana y la Reinvención de la Planificación Espacial: del Paradigma a la Práctica. Ciudad y Territorio. Estudios Territoriales, LI(202), 451-466.

Florida, R. (2020a, 3 de abril de 2020). The Geography of Coronavirus. Bloomberg CityLab. Recuperado de https://www.bloomberg.com/news/articles/2020-04-03/what-we-know-about-density-and-covi d-19-s-spread

Florida, R. (2020b, 19 de junio de 2020). This Is Not the End of Cities. Both the coronavirus pandemic and the Black Lives Matter movement create opportunities to reshape cities in more equitable ways. Bloomberg CityLab. Recuperado de https://www.bloomberg.com/news/features/2020-06-19/citieswill-survive-pandemics-and-protests

ACE, 15 (4.3) CC BY-ND 3.0 ES | UPC Barcelona, España | Hay que Defender la Ciudad: De la Distopía a la Ciudad 41 Abierta. DOI: http://dx.doi.org/10.5821/ace.15.43.9518 
Foucault, M. (1975). Surveiller et punir. París, Francia: Gallimard.

Foucault, M. (1999). Los anormales. Curso del Collège de France (1974-75). Madrid, España: Akal.

Foucault, M. (2008). Seguridad Territorio Población. Curso del Collège de France (1977-78). Madrid, España: Akal.

Friedman, U. (1 de mayo de 2020). I Have Seen the Future. And It's Not the Life We Knew. The Atlantic. Recuperado de https://www.theatlantic.com/politics/archive/2020/05/life-after-coronavirus-chinadenmark-south-korea/611011/

Gallion, A. y Eisner, S. (1950) The Urban Pattern. City Planning and Design New York, USA: Van Nostrand Company

García de Enterría, E. y Parejo, L. (1981). Lecciones de Derecho Urbanístico. Madrid, España: Civitas.

Gehl, J. (2010). Cities for People. Washington DC., United States: Island Press.

Giedion, S. (1948). Mechanization Takes Command. Oxford, United Kingdom: Oxford University Press. (Edición española, 1978. Barcelona, España: Gustavo Gili.)

Guerrand, R.H. (1991). Las Letrinas. Historia de la Higiene Urbana. Valencia, España: Edicions Alfons el Mágnánim.

Giddens, A. (1990). The Consequences of Modernity. Stanford, California, Estados Unidos: Stanford University Press.

Haggett, P. (2000). The Geographical Structure of Epidemics. Oxford, United Kingdom: University of Oxford Press.

Harris, J.E. (2020): The Subways Seeded the Massive Coronavirus Epidemic in New York City. The National Boureau of Economic Research. W.P.27021. Recuperado de https://www.nber.org/papers/w27021

Hauser, P. (1902). Madrid desde el punto de vista médico-social. (Reedición de la obra original de 1902 a cargo de Carmen del Moral). Madrid, Editora Nacional, 1979)

Healey, P. (2007). Urban Complexity and Spatial Strategies towards a relational planning for our times, New York-London: Routledge.

Hegemann, W \& Peets, E. (1922). American Vitruvius: An Architects' Handbook of Civic Art. New York. United States:Architectural Book Publishing. (Reedición New York. United States: Princeton Architectural Press 1988)

Hohenberg, P.M, y Lees, L.H. (1985). The Making of Urban Europe 1000-1950. Cambridge \& London. Harvard University Press.

Holder, S. (14 de mayo de 2020). Even the Pandemic Can't Kill the Open-Plan Office. Bloomberg CityLab. Recuperado de https://www.bloomberg.com/news/articles/2020-05-15/even-thepandemic-can-t-kill-the-open-plan-office

Jacobs, J. (1961). The Death and Life of Great American Cities. New York, Estados Unidos: Random House. (Edición castellana. 2011. Vida y Muerte de las Grandes Ciudades. Madrid, España: Capitán Swing Libros.)

Jackson, L. (2014). Dirty Old London. The Victorian Fight Against Filth. New Haven and London: Yale University Press.

ACE, 15 (4.3) CC BY-ND 3.0 ES | UPC Barcelona, España | Hay que Defender la Ciudad: De la Distopía a la Ciudad 42 Abierta. DOI: http://dx.doi.org/10.5821/ace.15.43.9518 
Johnson, S. (2006). The Ghost Map. The Story of London's Most Terrific Epidemic and How It Changed Science, Cities, and Modern World. London, United Kingdom: Riverhead books.

Klaus, I. (6 de abril de 2020). The Post-Pandemic Urban Future Is Already Here. The coronavirus crisis stands to dramatically reshape cities around the world. But the biggest revolutions in urban space may have begun before the pandemic. Bloomberg CityLab. Recuperado de https://www.bloomberg.com/news/articles/2020-04-06/how-will-the-pandemic-transform-urbanspace

Kling, S. (20 de abril de 2020). Is the City Itself the Problem? There's a long history of blaming urban areas rather than economic factors for physical and moral ills. But density can be an asset for fighting coronavirus. Bloomberg CityLab. Recuperado de https://www.bloomberg.com/news/articles/202004-20/the-long-history-of-demonizing-urban-density

Koch, T. (2005). Mapping the Miasma: Air, Health, and Place in Early Medical Mapping. Cartographic Perspectives, 52, 4-27. DOI: https://doi.org/10.14714/CP52.376

Kotkin, J. (26 de abril de 2020). Angelenos like their single-familiy sprawl. The coronavirus proves them right". Los Angeles Times.

Le Corbusier (1945). Manière de penser l'urbanisme. Boulogne-sur-Seine, France: Ed. L'Architecture d'Aujourd 'hui. (Edición española, 1976. Manera de pensar el urbanismo. Buenos Aires, Argentina: Infinito.)

Le Corbusier (1930). Précisions. Paris, Rancia: Cres (Edición española 1978: Precisiones. Barcelona, España: Poseidón.)

Levine, S. (2020). The Harsh Future of American Cities. GEN. Recuperado de https://gen.medium.com/the-harsh-future-of-american-cities-7263da52fd1f

Lynch, K. (1972). What time is that place? Cambridge, Massachusetts, United States: The MIT Press.

López Sallaberry, A. (1901). Memoria del proyecto sobre reforma de la calle Preciados y enlace de la plaza de Callao con la de Alcalá. Madrid, España: Imprenta Municipal.

Matthew, R.A. \& McDonald, B. (2006). Cities under Siege: Urban Planning and the Threat of Infectious Disease. Journal of the American Planning Association. 72(1), 383-389. DOI: https://doi.org/10.1080/01944360608976728

McNeill, W. (1976). Plagues and peoples. New York, United States: Anchor Press. (Edición española, 2016. Plagas y Pueblos. Madrid, España: Siglo XXI.)

Mumford, L. (1961). The City in History: Its Origins, Its Transformations, and Its Prospects. New York, United States: Harcourt. (Edición española: La Ciudad Historia. 1966. Buenos Aires: Argentina: Ediciones Infinito.)

Mumford, E. (2002). The CIAM Discourse on Urbanism, 1928-1960. Cambridge, Massachusetts: MIT Press.

O'Sullivan, F. (12 de junio de 2020, 2020a): Londoners Haven Become Afraid of Public Transit. Bloomberg CityLab. Recuperado de https://www.bloomberg.com/news/articles/2020-06-12/fear-ofpublic-transit-remains-high-in-london

O'Sullivan, F. (9 de junio de 2020, 2020b) In Japan and France, Riding Transit Looks Surprisingly Safe. Bloomberg CityLab. Recuperado de https://www.bloomberg.com/news/articles/2020-06-09/japanand-france-find-public-transit-seems-safe

ACE, 15 (4.3) CC BY-ND 3.0 ES | UPC Barcelona, España | Hay que Defender la Ciudad: De la Distopía a la Ciudad 43

Abierta. DOI: http://dx.doi.org/10.5821/ace.15.43.9518 
Patino, M. (15 de junio de 2020). Urban Living Might Just Survive Coronavirus. Bloomberg CityLab, Recuperado de https://www.bloomberg.com/news/articles/2020-06-15/urban-living-might-justsurvive-coronavirus

Pilmis, O. \& Castel, P. (12 de junio de 2020). Le vius des biais: ce que la crise du Covid-19 révéle du comportementalisme. AOC. Recuperado de https://aoc.media/analyse/2020/06/11/le-virus-des-biaisce-que-la-crise-du-covid-19-revele-du-comportementalisme/

Prieto, E. (2019). Historia medioambiental de la arquitectura. Madrid, España: Ediciones Cátedra.

Rosenthal, B.M. (23 de marzo de 2020). Density Is New York City's Big 'Enemy' in the Coronavirus Fight. The New York Times. Recuperado de https://www.nytimes.com/2020/03/23/nyregion/coronavirus-nyc-crowds-density.html

Rowe, C. \& Koetter, F. (1978). Collage City. Cambridge, Massachusetts, Estados Unidos: MIT Press. (Edición española, 1981. Ciudad Collage. Barcelona, España: Gustavo Gili.)

Sample, H. (2012) "Emergency urbanism and Preventive Architecture Urbanism. En Borasi, G y Zardini, M. Imperfect Health. The Medicalization of Architecture. Montreal, Canada: Canadian Center for Architecture.

Sassen, S. (1991). The Global City. New York, United States: Princeton University Press.

Secchi, B. (2013). La città dei ricchi e la città de poveri. Roma, Italia: Laterza.

Sennett, R. (24 de noviembre de 2015). The world wants more "porous" cities-so why don 't build them? The Guardian. Recuperado de https://www.theguardian.com/cities/2015/nov/27/delhielectronic-market-urbanist-dream

Sennett, R. (2018). Building and Dwelling: Ethics for the city. London, Reino Unido: Allen Lane.

Shenker, J. (26 de marzo de 2020). Cities after coronavirus: how Covid-19 could radically alter urban life Pandemics have always shaped cities - and from increased surveillance to 'de-densification' to new community activism, Covid-19 is doing it already. The Guardian.

Snow, J. (1849). On the Mode of Transmission of Cholera. London, United Kingdom: Churchill.

Snowden, F.M. (2020). Epidemics and Society. From the Black Death to the Present. New Haven \& London. Yale University Press.

Stein, C.S. (1950). Toward New Towns for America. 7a reimpresión, 1989. Cambridge, Massachusetts, Estados Unidos: MIT Press.

Tarchópulos, D. (2014). La Unidad Vecinal: Objeto de investigación de Josep Lluís Sert. En Congreso Internacional de Vivienda Colectiva Sostenible, (pp. 132-137). Barcelona, España: 25-27 de febrero de 2014, Máster Laboratorio de la Vivienda Sostenible del siglo XXI.

Terán, F. (1978). Planeamiento urbano en la España Contemporánea. Barcelona, España: Gustavo Gili.

The New York Times (11 de mayo de 2020). Opinion. The Coronavirus and The Cities We Need. The New York Times.

UN-Habitat (2015). International Guidelines on Urban and Territorial Planning, Nairobi, Kenya: UN Urban Settlements Programme.

UN-Habitat (2016). Urbanization and Development: Emerging Futures. World Cities Report 2016. Nairobi, Kenya: UN Urban Settlements Programme.

ACE, 15 (4.3) CC BY-ND 3.0 ES | UPC Barcelona, España | Hay que Defender la Ciudad: De la Distopía a la Ciudad 44 Abierta. DOI: http://dx.doi.org/10.5821/ace.15.43.9518 
UN-Habitat; Sennet, R.; Burdett, R.; Sassen, S. \& Clos, J. (2018). The Quito Papers and The New Urban Agenda. New York, United States: Routledge.

Urteaga, L. (1985). Higienismo y ambientalismo en la medicina decimonónica. Dynamics: Acta hispanica ad medicinae scientiarumque historiam illustrandam, 5-6(1985-1986), 417-425. Recuperado de https://www.divulgameteo.es/ampliab/4/555/Higienismo-y-ambientalismo-en-la-medicinadecimononica.html

Urteaga, L. (1980). Miseria, miasmas y microbios. Las topografías médicas y el estudio del medio ambiente en el siglo XIX. Geocrítica, 29, 5-38. Recuperado de http://www.ub.edu/geocrit/geo29.htm

VV. AA. (2019). Agenda Urbana Española 2019. Madrid, España: Gobierno de España. Ministerio de Fomento - Secretaría General Técnica.

Vigarello, G. (1993). Lo sano y lo malsano. Historia de las prácticas de la salud desde la Edad Media hasta nuestros días. Madrid, España: Adaba editors.

Webber, M. (1964). The Urban Place and The Non-Place Urban Realm. En Webber, M. et al. (Eds.), Explorations into Urban Structure Philadelphia (pp.73-140). University of Pennsylvania Press. (Edición Española, 1974. Barcelona, España: Gustavo Gili.)

Wolfrum, S. et al. (2018). Porous City. From Metaphor to Urban Agenda. Basel, Germany: Birkhäuser Verlag $\mathrm{GmbH}$.

Yong, E. (28 de marzo de 2020). How the Pandemic Will End. The U.S. may end up with the worst COVID-19 outbreak in the industrialized world. This is how it's going to play out. The Atlantic. Recuperado de https://www.theatlantic.com/health/archive/2020/03/how-will-coronavirusend/608719/

Yuko, E. (12 de junio de 2020). What-Happened When the Office Came Home. Bloomberg CityLab. Recuperado de https://www.bloomberg.com/news/articles/2020-06-11/the-rise-fall-and-rise-ofthe-home-office

Zeiba, D. (2020). Architecture and Illness: Beatriz Colomina On Tuberculosis, Modernism, And COVID19. PIN-UP 28, Spring Summer 2020. Recuperado de https://pinupmagazine.org/articles/interviewbeatriz-colomina-x-ray-architecture-drew-zeiba

ACE, 15 (4.3) CC BY-ND 3.0 ES | UPC Barcelona, España | Hay que Defender la Ciudad: De la Distopía a la Ciudad

Abierta. DOI: http://dx.doi.org/10.5821/ace.15.43.9518 